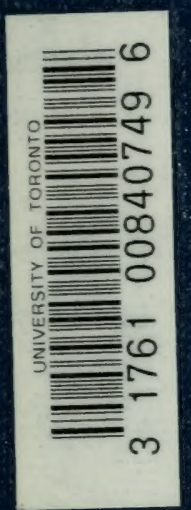






\section{In a Fishing Country}





\title{
In a Fishing Country
}

\author{
By \\ W. H. Blake
}

Author of 'Brown Waters', \&c.

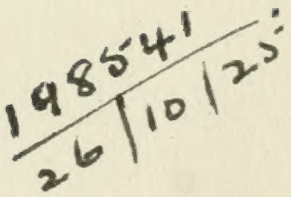

TORONTO: THE MACMILLAN COMPANY OF CANADA, LTD., AT ST. MARTIN'S HOUSE MCMXXII. 
COPYRIGHT, CANADA, 1922
By THE MACMILLAN COMPANY OF CANADA, LIMITED.

$$
\begin{aligned}
& \text { SH } \\
& 572 \\
& \text { Q3B55 }
\end{aligned}
$$




\section{CONTENTS}

PAGE

I Old Murray Bay . . . . . . . . 9

II Lac Emmurailié . . . . . . . . 77

III The Quêteux . . . . . . . . 105

IV Proving the Rule . . . . . . . 111

V The River . . . . . . . . . . 143

VI JACK-o'-LANTERN . . . . . . . . 149

VII T— . . . . . . . . . . 179

VIII $\mathrm{N}-$. . . . . . . . . 199

iX Ways and Means . . . . . . . 213

X The Brook Trout . . . . . . . 257 



$$
\begin{aligned}
& \text { The Cs and the Ms.: } \\
& \text { Who helped to make the trails: } \\
& \text { Who will keep them clear } \\
& \text { in days to come. }
\end{aligned}
$$

Pointe au Pic, P. Q., June, 1922. 

OLD MURRAY BAY. 



\section{OLD MURRAY BAY}

AFTER seventy years have sped-happy years leaving few traces of their eventless passing-it is none so easy to breathe the breath of life into that 'little summer colony mostly from Quebec and Montreal' which Mr. Wrong in his Canadian Manor and its Seigneurs tells us was to be found at Pointe au Pic in 1850. Recollections are dimmed and unsure; of chronicles scarce any exist. The hour slips by for recording somewhat of ways and manners that are within the fading memory of a bare handful; well-nigh as remote and strange to the new comer as the daily walk and conversation of the King's Farmer when he was shooting bears from his door-step and spearing salmon beside his house in the stream then famed before others as La Rivière Saumonais.

Before sitting down to sort what miscellaneous jetsam time has left stranded, I attempt two or three long backward casts, and it is but kindly and honest to announce the intent to ease the task of the judicious reader who skips irrelevancies.

First then, without argument or cavil, it is freely allowed that the age and genesis 


\section{IN A FISHING COUNTRY}

of whatsoever hides bencath his beloved turf is highly irrelevant to the golfer's foot.

The day was, and not long since, when geologists held the Laurentian granite to be the first visible link of a disappearing chain; but the cosmic book-keeping is amended, and drafts upon an unexpected fund of years found lying to credit, balance the new accounting. With enlarged scope for immeasurable processes, fresh mountain ranges have been tossed in air and weathered to dust through ages of ages, continents have been sunk a thousand fathom deep or built up from the abyssal depths of ocean. In place of the lore of our childhood we are taught to believe that the Laurentians thrust up through older sedimentaries of such vast thickness that their deposit exhausted unimaginable aeons. Nothing remains near Murray Bay of these miles of ancient crust. The mountains themselves-perhaps the loftiest ever reared to the heavens-are worn to the very roots, yet still we may reverently view them as the oldest Plutonic rocks exposed on the earth's surface, and only the greognostic is likely to detect in them the down-at-heel look of mountains which have seen better days. 


\section{OLD MURRAY BAY}

Times and again the sea covered all this land; times and again the ice invaded it, rose thousands of feet above it-planing, smoothing, rounding whatever lay athwart its flow, hollowing lake-beds, building moraines, transporting myriads of boulders from afar, grinding the clays that filled the Murray valley from side to side ere its river made an end of the task on which the milky Mailloux still is busy. The limestones along the coast were laid down during an early submergence, a later one accounts for some beds of fossils - such a bed lies buried under the railway at the Point.

But those features which the eye is apt to remark as most singular and arrestive were shaped in a very late chapter of the earth's long record. The St. Lawrence itself, reckoning in geologic measures of time, is no ancient river. Unbroken land once shutting away the Atlantic from the Continental Sea was rent and sunk to form the channel. The strata dipping to the bold northern shore mark the line of this gigantic fault, of which the cliffs at Montmorenci and Cap à l'Aigle are fresh memorials. It may well be that the earthquake which began on the dire Shrovetide of 1663 and lasted for seven months was a further sub- 


\section{IN A FISHING COUNTRY}

sidence. The St. Lawrence ran white to Tadousac for the space of three months. Mountains were engulfed and islands arose. The forests bowed themselves and lakes went dry. Les Eboulements won the name of menace that it bears. The Jesuit Fathers tell us how that opposite Trois Rivières those voiceless creatures the white whales filled the air with piteous sound. In later years there followed other shocks, and insignificant ones are not at all uncommon even now.

The casual visitor, adventuring no farther than the golf links, expends a mild wonder upon the odd mounds and ridges he is invited to play round or over. They have been laid to the swirling of mighty tides when the Murray valley was a narrowmouthed deep fiord, and again to the hand of man. The late Sir Daniel Wilson held the latter opinion because of their symmetry and disposition, and dug into one or more in search of Indian remains, but found only glacial till and boulders. Very clearly they are relics of the latest ice-age, after the final uplift of the land; belonging, geologically, to the hour whose striking still echoes in our ears. When the 'Ridge' was the beach-line, an expiring glacier unloaded 


\section{OLD MURRAY BAY}

its burdens in these kames and drumlins on the tide-scoured flats.

The raised beaches of this and the Baie St. Paul valley show the stages of the land's rise-perhaps when relieved of ice. Those at 60,300 , and 600 feet above tide-water (speaking roughly) are so well-marked and continuous-plain to see as railway embankments - that it might be hard to match them elsewhere. Another at 900 feet is less easy to follow, but above it, and far inland, signs abound of a much higher sea-level in recent times. And the scientific mind may find significance in this: fifty miles back in the mountains, 2000 feet above the sea, a little isolated lake snuggles in a bed delved for it by the ice. A strictly lacustrine fish of very set habits dwells there, much over a thousand miles from its proper home. The retiring sea must have left this rare arctic charr behind after the departure of the ice -left it to testify as to the time and order of events.

A reading of the Sagas which assigns winter quarters to the Norsemen within a modern cannon-shot of Murray Bay must interest anyone who has had the good sense to cultivate a reasonable taste for argument. Professor Steensby, writing in 1918, re- 


\section{IN A FISHING COUNTRY}

views those narratives where fact passes perplexingly into fable, seeks (like so many another) to follow the explorers in their voyaging, and pitches upon St. Thomas on the South Shore as their final landfalltheir Vinland. They came (it will be remembered) to a place abounding in grapes, and it is noteworthy that St. Thomas is just below the Island of Orleans where Jacques Cartier found such a plenty of the wild grape that he named it L'Isle de Bacchus. We may not cruise with the writer to Helluland and Markland in the Norsemen's wake, past cape, fiord and strand, hard to pick up through the fogs of time, but a few words of comment should be within your patience. 'The Wonderful Beaches' fit amazingly with the sands of the Quebec Labrador. Pointe des Monts is not the stumblingblock that Steensby imagined. Had he known the river otherwise than by maps he might have found in Isle aux Coudres a likelier 'Straumsey' than Hare Island offers him. And the fierce tides and rips of the northern channel bring 'Straumsfiord' to mind. His guess is uncommonly reasonable and persuasive that sea-beaten marincrs in small craft would choose to coast a new-found shore rather than launch darkly 


\section{OLD MURRAY BAY}

south and east into the unknown. Though the writer seems to be alone in his opinion and Nansen's ponderous treatise leaves the question wholly at large, while the scores of earlier commentators follow each his own course to differing landfalls, the assertion is a very moderate one that the St. Lawrence theory cannot be thrown lightly aside. Fix the Norsemen's Hóp where you will, you come in clash with one part of the story or another-must select and reject in accordance with some individual conception of the probabilities, and the narratives are strained no more than they have to be in any other case by the interpretation which brings the adventurers of 900 years ago within hail of Murray Bay.

There are passages in the Sagas which Steensby and Nansen alike disregard as corrupt and meaningless. Rushing in, may-be with the swift-footedness which distinguishes fools from angels, I suggest that they are of high significance, yielding a singular proof that the tale is not born of the imagination but is an artless record of dimly-remembered fact. It is related that the Skraelings (savages) descended upon the Norse encampment from the south in their 'skin boats' (more probably Indians in 


\section{IN A FISHING COUNTRY}

bark canoes than Esquimaux in kayaks or oomiaks). Some bore staves which they waved with the sun. Karlsefni's men deemed this a bid for peace, and raised a white shield in token of understanding and amity. Whereupon the visitors came ashore and engaged in friendly barter. Some three weeks later the savages are back again, but this time the staves circle contrariwise. Once more the Norsemen spell out the meaning and now display a red shield, discerning hostile intent and accepting the proffer of battle. Forthwith the savages land and the forces close in bloody strife.

Where each word is pondered and weighed to sift the true from the fabulous, any rejection weakens and discredits, every acceptance fortifies the whole. Should this be in truth a vivid and dramatic account of the first interchange between the inhabitants of two continents through motions familiar to both as benign and sinister, how much of verisimilitude it adds to every point of the narration!

I confess that the surmise invites a foot all too prone to stray--provokes an incorrigibly gadding mind to divagate! Everyone should know that there is but one proper 18 


\section{OLD MURRAY BAY}

way to carry a coffin about a grave, coil a rope, stir porridge, dismiss a milked cow, turn a boat to sea, deal at cards, send round the wine, do a hundred other things-from right to left. Whereas a witch in accosting her master the devil must at her peril draw near him withershins, for this is the ritual approach in the practice of all black magic. Sir James Frazer (to whom speculations such as these are more than meat or drink) suggests that the two turns with their respective trains of consequences took character in the beginning from the superior luckiness of the right hand, which is presented to and kept towards an object when you circle to the left. This luckiness, he admits, is a matter of pure conjecture. The hypothesis is discardable as unnecessary, if it be shown that beneficent and maleficent incidents have otherwise become woven into the very fabric of the turns. Then the hand will borrow reputation from the turn rather than the turn be in debt to the hand. May the wherewithal for two sets of contrasting beliefs not be found in primitive observations of the wind's shifts and the weather's responses, and the inevitable reasoning thereon of credulous awakening minds? 


\section{IN A FISHING COUNTRY}

Consider. From those earliest days when our ancestors began to raise their keener eyes skyward, they assuredly knew that a wind shifting from east to west by the south brings fair weather-is a lucky wind; that a backing wind ushers in foul weather -bodes ill: vital facts to them for every purpose of their lives. Nothing less than existence itself depending on the temper of the heavens, would not these unfailing sequences engender and perpetually nourish the conviction that the rotations were lucky or unlucky at all times, in every association?

It has been said that the path of the sun across the sky impressed those living north of the equator with the idea that such a motion was in harmony with the order of nature. The conception may have grown up with and become confused with the other; but the sun provides no contrast of circuits or concomitants, the notion of attendant good fortune has to be lugged in, body and bones, and that of evil fortune must be built up out of nothing, to suit the theory.

It is worth recalling that a lost man always circles in the unlucky sense-showing that for some reason (probably constitutional to the human brain) the natural turn is from left to right-showing also that 20 


\section{OLD MURRAY BAY}

our inveterate favouring of the other turn is an aberration for which we have to seek a cause. Note, parenthetically, that the old puzzle of the English rule of the road for vehicles yields to this explanation-based upon a settled practice likely to antedate by thousands of years the invention of the wheel. (Pedestrians in England are in a transition stage, without uniform habit or rule-unless shepherded.)

But more than the individual's personal welfare depended upon his making the deiseal and not the withershins turn-still is believed to depend, indeed, for I have seen a man of the dullest and soberest leave a table where the wine was sent about to the right. The course you held in approaching man or dwelling announced you as the bearer of good or evil fortune, declared your attitude, intimated good will or tendered affront. The ancient superstition, now blindly lingering in odd by-ways, once dominated conduct as a rigid and reasoned convention. There was no mistaking the signification of the turns. So may it well be that the savages, with these auspicious and inauspicious movements of their staves, were speaking in a universal language comprehended of the Norsemen, and that the 21 


\section{IN A FISHING COUNTRY}

incidents supply convincing internal evidence of the chronicle's authenticity.

I am in two moods at lighting upon confirmation of a sort in Mr. G. M. GathorneHardy's The Norse Discoverers of America (1921). He describes the events as 'a genuine and interesting use of a sign correctly interpreted by the Norsemen', and asserts 'the prevalence in America, as in most other countries, of the ceremonial use of solar and contra-solar motions'. But I have not been fortunate enough to find in the British Museum's edition of the book to which he refers in support-Myths of the New World by D. G. Brinton (1868)-the slenderest reference to 'contra-solar motions,' nor to 'solar motions' in the sense described.

A steamer was plying between Quebec and Tadousac in 1846. After much secking I rested upon this date, until there fell into my hands through a friend's kindness the Journal of an Expedition for Exploring the Country between the Rivers St. Lawrence and Saguenay, as far as $H a H a$ $B a y ;$ by Nich. Andrews. It was rather amazing to read his entry for Sunday, Sep. 19th, 1829, made at Pointe au Pic:-'Nothing particular to-day, save that the Waterloo Steamboat came down here on a pleas22 


\section{OLD MURRAY BAY}

ure trip.' Sunday excursions a century ago!-but our later knowledge of the river navigation moves one to the charitable conjecture that she was due upon the Saturday! Mr. Andrews having served me this good turn, I refuse to quit his company in uncivil haste.

His narrative discloses how singularly little was known of the country 'to the north of the River and Gulph of St. Lawrence, commonly called the King's Posts'. The instructions committed to him under the authority of the 'Knights, Citizens and Burgesses of Lower Canada in Provincial Parliament assembled' must have embraced the finding of a volcano, for Andrews declares that if one exists he will do his 'best to discover it', and later he expresses the opinion that:- - it must be beyond the Ste. Anne, in a range of high Mountains to the Westward of it'. This persistent tradition, perhaps not utterly dead even now, may be a distant echo of those months of terror in 1663 when the earth shook and the heavens dropped.

Andrews landed at the Grand Débarquement, to-day called Le Port; then, as now, the hard for schooners. He lodged at Chaperon's inn which stands yet, if I mistake not, on the rocky point near the mouth of 
the Murray. The inn-keeping trade ran in the family, for a George Chaperon was his host later at Baie St. Paul.

In neither place was he able to get information of the interior. The French scemed to have no knowledge, the Indians were chary of imparting it. At length one Girard agreed to lead him through the 'pass of the Mountains' (the Passe des Monts, where ascends the present St. Urbain road) and conduct him to 'Malbay' by a detour.

The journal of this endeavour might have been written yesterday by an untried and rather wretched explorer:- 'The country through which we travelled was all but impenetrable. The old fallen trees lay so thick, and overgrown with Saplings and Brushwood, that we could not see each other at the distance of four yards... We were much fatigued when we encamped, and our Clothes all torn. The Swarms of Mosquitoes tormented us extremely, and they are the only living thing we have seen to-day, not even a Bird or a Squirrel made its appearance ... the whole is almost one continued burnt ficld, excepting round the little Lakes, and in the Vallies... We encamped by the side of a fine little Lake, much fatigued and hungry. The men tried 


\section{OLD MURRAY BAY}

with the hook and line, but could catch no fish. . . We met with a bank of snow from four to six feet deep, although exposed to the midday sun.' (July 2nd.) After some toilsome marches he worked his way out behind the Grand Lac, and took three hours to walk round it to the first habitations at the Petit Lac where he was glad to put up at the house of Mr. Gaye 'very much harrassed and fatigued'.

Andrews' next attempt was to win to the back country by the 'Malbay River'. Purchasing a canoe, for which he had to pay five dollars, and starting inauspiciously on a Friday, he had much ado to make the seigniorial line by nightfall-camping 'a little above Harris's Saw Mill'. The next day they laboured up the rapids (Andrews scrambling along the bank) till the canoe was half full of water and the men 'entirely discouraged'... 'With a long and difficult rapid before us to which we could see no end' the struggle was abandoned. That it was begun shows how little was known of the Murray as a waterway.

Striking out nor'eastward on the line of the Chemin des Marais it was the same story. "We had, for the most part, to walk upon fallen trees, crossing each other, three or 25 


\section{IN A FISHING COUNTRY}

lour feet high, and upon large stones, round which the earth is all burnt to ashes ... We tore our hands, faces and clothes, every instant. . We were all as black as negroes, from the effects of the burnt wood and sweat . . We had little or no rest last night from the rain and the mosquitoes' but 'I gave my men a bottle of spirits with their supper which made them forget their fatigues ...'

Nich. Andrews' journal is dearly remindful of other explorings in these parts fifty years later-forty years ago-the trivial inconveniences forgot, one fingers the yellow page and dreams

A single other extract must I give for a personal reason: because it bears out a private notion of my own that fish are deteriorating in size and fighting quality. He was on the St. Lawrence, near the Baic des Rochers, when this befell him:-

"We had not proceeded far when we were pursued by a monstrous fish of prey, in consequence of which we put ashore again. This animal was four hours about us, and apparently watching us. It came sometimes within twenty feet of the rock on which we were. It was at least from twenty to twenty-five feet long, and shaped 


\section{OLD MURRAY BAY}

exactly like a pike; its jaws were from five to six feet long with a row of large teeth on each side of a yellowish colour. It kept itself sometimes for nearly a minute on the surface of the water. At 5 P.M. seeing nothing more of it, we embarked again, keeping close in shore...'Alas that such chances never come our way to-day!

Through the manor-houses, Murray Bay must have kept touch with the outside world from the time of the English grants, and by 1840 a few had learned the way to the inaccessible place and had found it good. The Murray's repute for salmon brought stray visitors-as the well-known Dr. Henry in 1830; but his account of a four days' passage from Quebec in a filthy and crowded schooner would discourage anyone not a daft fisherman from the venture. Those who faced the hardships were able to lodge comfortably-bedroom, sitting-room and board-at $\$ 10$ the month.

The steamer that ran occasionally to Tadousac in 1846 used to land passengers for Murray Bay in small boats at the Petit Débarquement under the Point, there being then good water within the curve of the bar; perhaps also at Pointe à Gaze on the Cap à l'Aigle shore. Although the reefs 


\section{IN A FISHING COUNTRY}

and banks have greatly extended within living memory, the bay itself was always an evil place for navigators, dry at ebb-tide and perilous with shoals and boulders at the flood. Champlain, caught there, named it Malle Baye, and the river flowing in a many-channelled course through the sands, La Rivière Platte.

Octogenarians recall the days when Cap a l'Aigle was the goal rather than Pointe au Pic. Advantaged thus, and with its other happy endowments, the lower would have been the more important side of the bay had a forgotten dispute ended differently. Fancy entertains itself in deploying the villas of Pointe au Pic where Cap à l'Aigle's long road runs tranquilly through farms, but those who dwell there unpretentiously may little regret that this is only the fabric of a vision.

Pointe au Pic and Pointe à Gaze were rivals for a promised wharf. All the countryside threw its weight into the political scale, which, like any other just balance, tipped in favour of the out-numbering electors on the hither side. So it came about that in 1852 at Pointe au Pic the wharf was built-henceforth the Grand Débarquement-and many remote 28 


\section{OLD MURRAY BAY}

unguessed fates were set in train for the disputants. The 'Saguenay' began in that year the regular sailings to Murray Bay which she still maintains.

A word as to names, for those who concern themselves about such things. There are who choose to write 'Pointe à Pic' -asserting earlier usage (incorrectly, I believe) and a neater derivation: 'the steep headland'. But Pointe au Pic derives itself well enough, in accordance with other coastwise names, and has been the proper mode these hundred years and more. It is suggested that 'Pointe à Gaze should be 'Pointe à Gaz'-from marsh gas visible on the tidal flats as feux follets, but evidence of the Jack-o'-lanterns is to seek; another explanation turns lamely upon gauzy mists supposed to haunt this shore, and a helpful friend even conjures up a 'Gaze' family associated with this spot but sunk without trace in the ocean of time. One may be allowed the conjecture that upon a coast where many French names have been rudely and ignorantly dealt with ('Fame' for Faim, 'Bull' for Boule, 'Armour' for Amour, 'Chat' for Chaste, 'Despair' for D'Espoir, and so on) the converse process may have been in operation, and 


\section{IN A FISHING COUNTRY}

the 'Look-out' or 'Gaze' Point of the first English settlers have become 'Pointe à Gaze'. The sins are not all on the one side. English geographers are blamed for wresting from the Sieur de Monts a proper record of his achievements when they write 'Pointe des Monts'. And yet de Monts did not name the Cape, nor even see it as far as 1 can discover, and this was the land of the Saurages des Monts P'elés before he sailed the Gulf. The earliest maps prove the case. Colonel Nairne stipulated in 1762 that his seigniory should be called 'Murray's Bay'. This appears to have slipped into 'Murray Bay'-still officially the name of the village, I believe, though 'Malbaie' is alternatively proper for bay and river, and the tendency in all cases is to revert to the Champlain christening. An error in Thwaite's monumental edition of the $R e$ lations des Jesuites is worth correcting. Malbaic is there derived from 'Baie des Moluës'-transposed and mishandled; molvie being the old form of morue, meaning 'cod'. This is true of the Gaspé Malbaie, but not of the place to which the note is directed. Lac à Gravel takes name from the Indian who found the lake, or harboured there before time of memory. The 


\section{OLD MURRAY BAY}

Rivière à Comporté preserves the name of the first Seignior, and the earliest settlement in the valley was probably about the mouth of this sadly diminished stream. 'Beulah' had its baptism less than fifty years ago from one whose eyes were opened to see that '... in this land the Shining Ones commonly walked, because it was upon the borders of heaven.'

The road to Quebec was not completed until 1856, but was open between Murray Bay and Baie St. Paul more than half a century earlier. The St. Urbain road (to $\mathrm{Ha} \mathrm{Ha}$ Bay) was finished about 1865 . When the house now standing at the corner of the Quebec road and the village street was built, there was no road passing it and crossing the Point, but there was access along the water's edge to the Petit Débarquement already mentioned; a highway followed speedily upon the building of the wharf. The Point and the land about it must have been cleared or burned over in early times, for old photographs show a covering of the merest scrub. The Boulevard is, of course, a recent creation; one could wish it had retained the name given it - the Chemin des Falaises-but the commonplace triumphed. Many ancient foot- 


\section{IN A FISHING COUNTRY}

paths traverse the wooded hillsides; short cuts from settlement to settlement, or direct ways to beaches and fisheries. It is certain that some of them, now hard even to trace, have been in use for above two hundred years; perhaps indeed for a vastly longer time as aboriginal trails. The extinct industry of smuggling suggests itself here and there as an explanation. (Only in our own day have nomadic Indians deserted the country. Their summer lodges near the wharf, where they wove baskets and built canoes for a living, are within memory.

Georges Duberger first offered the accommodations of a hotel to the summer migrant about 1850 . This landmark, where the house of M. Edouard Warren now stands, was swept away by the fire of 1894 , with some forty cottages in the very heart of Pointe au Pic. Madame Micheletti's boarding-house, near Duherger's, and now fading into the mists of fifty years ago, calls up a single undimmed picture. A little milk-shed with shelves and bowls to the roof: the stage. Two lads and a Newfoundland dog that looms gigantic: the actors. Might the shed contain the dog? There was no guilty mind, merely a ory. 


\section{OLD MURRAY BAY}

curiosity that would not down; the only way to solve the rexing problem was by experiment. The animal was coaxed and shoved in, but at the shutting of the door a claustrophobia seized upon him. The noises that issued forth were of a distraught dog revolving at prodigious speed in a vortex of cream and crockery. So funny did it sound that the boys rolled on the ground in their delight, but the delicious humour of the thing completely escaped everyone clse-even when Madame at last freed their dizzy, howling, blinded, milk-white playfellow. And still when the day is very fair, offering a thousand pleasant ways of passing it, a fear stalks out of the shadows that I shall miss them all, for Someone will despatch mesuddenly to bed.

Not yet was Chamard's, but before 1870 M. George Warren built the 'Rivers' ie House' a little south of the Protestant church, and in the year mentioned M. John Chamard leased the place, naming it the 'Lorne House'. He was a thin, wiry man of clear-cut features, alert for the comfort of all beneath his roof, having a word for every occasion, with a politeness that was no garment to be put on and laid aside. His good wife I summon back as the clev- 


\section{IN A FISHING COUNTRY}

erest cook that ever cheered a hungry boy. Our little trout from neighbouring brooks received attentions due worthier fish.

A lesson of 1873 must survive by grace of some preservative moral quality. Driving back to Chamard's from Brassard's creek, as then it was called-the tiny burn that joins the Mailloux just below the mauraise côte (the côte Brassard) - a young acquaintance hailed with the immemorial question:- 'what luck?' I recall no disposition towards reticence, perhaps there was even a shade of eagerness in the refly:-'nine dozen'. Whereupon my father rebuked the flagrant boastfulness of the answer, and the small boy called me a liar! Pondering the incident after this decent lapse of time the principle seems to emerge that it is often as inexpedient to tell the truth as to lie-unnecessarily.

The moment is convenient for confiding to any worthy youngster between the ages of ten and seventy that all the little streams within a dozen miles of Pointe au Pic, save only the Petit Ruisseau, still hold trout; and will yield a basket to one who pushes beyond the beaten track with two joints of a stiff rod, plenty of good worms, and a boy's heart. 


\section{OLD MURRAY BAY}

In 1878 M. John Chamard built his secund 'Lorne House' above the wharf, not far from the old 'artificial lake'. Unbeautiful it was, how charitable soever the beholder's eye, but few inns of such modest pretension have had the fortune to gather about them a happier lot of memories. John Chamard's first summer there was his last, for the schooner he chartered and loaded at Quebec with a season's supplies was cast away on Crane Island. He perished with all hands and nothing was salvaged from the wreck. The mainstay of the family gone, with all its resources, the hotel went bravely forward under the well-remembered guidance of M. William Chamard till 1900, when the land passed with cruel unexpectedness to other hands and the Manoir Richelieu was built. Thanks to one who will always be held in affectionate regard, Chamard's did not vanish from the earth, but this institution, rooted deeply into the past of Murray Bay, survives with all the honourable and kindly traditions of other days.

Steamers and a wharf simplifying the journey for families, a slender but evergrowing stream of summer travel began. The first-comers lodged at Duberger's or 


\section{IN A FISHING COUNTRY}

Warren's and in boarding-houses of the simplest; or they took orer the cottages of the residents-these retiring to mysterious quarters not designed as habitations. Thirty or forty dollars a season. wood and water included, was the rent for a cottage that satisfied unexacting people who were in a spirit to rough it; -were ready to take what was offered them, and accept unfamiliar discomforts in good humour. Narrow indeed the space then sufficing for the larger families, the greater number of guests.

By 1866 the 'little summer colnny' had acquired some character of permanency; the Protestant church, built in that year with seats for perhaps 250 penple, fairly measured it. A memoir of this church has been written to which I make bold to add a foot-note. Resting upon twin Anglican and Presbyterian pillars, the portals stand open to beliefs widely sundered in thenry. Those who enter come not upon invitation, as tolerated in charity, but each in his own right to his own place-acknowledging no more, perhaps, than the brief essential credo:- 'I believe.' Tt is surely no sentimental fancy that half a century of unconstrained reunion has filled the little temple 


\section{OLD MURRAY BAY}

with a serene air of goodwill and peace. Memorable not alone for this catholicity, the custom of two peoples and of two races has been there to assemble upon solemn occasions of rejoicing and mourning,occasions when the conviction of brotherhood, common destiny and ultimate oneness of faith has surged above all the dividing barriers.

It was in 1866 also that a group or Montreal gentlemen bought land above the wharf and began to put up cottages. Lumber was of little account, and deals sold for $\$ 3.50$ the hundred, but even at that the builder knew how to better the tally by sending the schooner to the mills for a load ballasted with a jar or two of whisky. In those earlier houses the deals lie flat, one upon the other-a construction that would be ruinous to-day at an advance of 2000 per cent. in cost of the material. Open fireplaces to burn wood were devices beyond local experience, constructed only with much head-shaking, at owner's risk. There was no plumbing, for every household looked to its own springs or wells for water. The literal tub was conceded to the ladies who would not dare the St. Lawrence, but the males of all ages bathed in puris along 


\section{IN A FISHING COUNTRY}

the shore. Some chose the sands at the Murray's mouth, where the salt water was a little tempered; others the ledges near the Protestant church (who remain to identify the red rock where the buys were wont to gather at high tide?) 'The Puint' resorted to the white rocks below the cliff, or found good depth above the wharf for a dive at all tides, and a waterfall to give a chill and stinging shower-bath. Every morning, one with a long white beard (beloved at allother hours of the twenty-four) made the round of the cottages, booming out 'show a leg, boys, show a leg, show a leg', till the sleepy crew in varied undress rallied and straggled after him to the beach. Nor wits nor pity won escape from the regulation three plunges; were the evasion discovered late, in you must to complete the tale at any stage of dressing, no tender hands aiding. I remember a venerable man, a bishop, who swam seaward from the white rocks till the strong ebb-tide was carrying him away. Someone shouted a warning, and I see his shiny head and hear his cheerful hail:--'all right boys, I'll land on the sand-bar'! He and a few others were little troubled by the coldness of the water. While not pretending it was the 38 


\section{OLD MURRAY BAY}

same with the rest of us, I stoutly maintain that the swimming at Murray Bay was, and again might be utterly health-giving, but alas the ancient spots are public and defiled.

Everyone lived upon the country,-faring well on fish, mutton, fowls, eggs, the homelier vegetables, wild fruits, cream sevcred in nature's leisurely way beyond risk of confusion with the parent milk. Partridges were thirty cents the brace. It may be kinder to the modern housewife to cease from comparisons. Le petit jardinage did not engage the habitant, who gave intensive culture alone to his tobacco; a taste of the exotic fruits of the earth depended upon the occasional barrel by steamer. Very large bullseyes, unmanageable whether one strove to bite them, or suck them in their integrity, were to be had; also la tire-from a pedlar whose hands thrust upon all but famished youth uncomfortable thoughts of how and where the maple sugar had been pulled.

Sucre d'érable was then the staple, but when it rose in price to ten cents a pound, coarse brown sugar slowly replaced it with the country folk. An odd economic progress,- that an indispensable for the poor 


\section{IN A FISHING COUNTRY}

should become a luxury of the rich. Sucre it la creme was more than a sweetmeat; the confecting of it was a joyous rite, attended with song and dance. At dinner, let us suppose (it was then a midday meal, with high tea in the evening) some one uiters a word that flies down the long table. Presently all is arranged. A couple are detailed to buy maple sugar in the 'far-village'; another couple must raid the farm-houses for thick cream, no worse if sour; three or four are charged with making sandwiches, cakes, lemonade; others will bear about the fiery cross, bidding the guests. These arrive with the stars, and in their best-no better, I confess, than muslins for the girls, flannels for the boys-to find the flames already licking a huge iron pot. They dispose themselves with rugs and cushions upon the rocks, while the choir gathers round the blaze. Catches and chorusesno limit to the common stock of these-follow the sugar through the stages of its boiling, till the cold water test is passed. Then the pot heads a musical procession of all hands to the rorrs of buttered plates in the kitchen, and the cook watches the sugaring with some tremors. For him the truest proof will be in the eating, and the most 40 


\section{OLD MURRAY BAY}

flattering criticism that none shall remain against the morrow. And now the floor is cleared, relays of musicians provided for the piano, and the planks spring to the old measures. Should things move too staidly they are speeded on their way by jig, fling, broom or garter dance. At length come Auld Lang Syne and Bon Soir mes Amis. Laughter and snatches of song drift back from groups departing into the darkness. Their lanterns flicker through the trees. The fire has burned away to red embers. The quiet voice of the tides across the bar, ceaseless but ever changing, steals again into possession of the night.

The spirit informing the reillée of yore was: Come, mes amis, let us be merry together, each after his kind, according to his gifts. Now is it rather: Go ye, dance, sing, fiddle,-hirelings for our amusing.

There was much sailing, rowing, paddling; but the great river, with currents of five or six knots an hour, and winds that suddenly arise, allows of no trifling. The part of wisdom is to use the same degree of caution at all times, and that the extremest; for a capsize in such water is like to be deadly serious. Even where deliberate risks are avoided, awkward moments may 


\section{IN A FISHING COUNTRY}

come that will test both nerve and skill. Knowledge of the set of the tides teaches how the dangerous rips can be avoided, and shortens many a long mile. A very old hand at navigating the St. Lawrence in small boats preferred to row the fifteen miles from Port au Persil to Murray Bay against the tide,-coaxing more help? from the in-shore eddies of the ebb than he could win from the weaker flood. That strange confluence of currents known as the Danse des Marées, a few hundred yards outside the wharf, is an uncomfortable spot if there be the lightest breeze against a strong flowing tide. A canoe that might otherwise cross the wide stream in perfect safety, would be in peril there. The ablest yacht cannot beat against the ebbs,- - something it is well to have in mind when planning an afternoon's sail. These little jaunts had a way of lasting for twenty-four hours; and some will remember the sleepless starving nights in shirt-sleeves, off Cap Saumon or Nine-mile Point, and the fierce competition throughout the dark hours to be allowed to warm up at the sweeps. Many a time too the rent de la tere-last movement of air as the perfect summer day draws to its close-won for us a Christian bed instead of a cold plank. 


\section{OLD MURRAY BAY}

Cruising was a sport within the reach of a youngster's pocket. Ten of us once chartered a well-found schooner, with two men and a boy; fished half a dozen of the best salmon and sea trout rivers on this side of Pointe des Monts; had our fill of good sailing for nearly a fortnight, and, as the log shows, shared up an expense of $\$ 7.20$ a day!

Both shores lack safe and comfortable harbours; when caught by an up or down river blow you may have to run a long way for shelter. We were working home from Ste. Anne des Monts, where the width of the St. Lawrence is above forty miles, in a very ancient pilot boat. Early in the afternoon the light breeze died away, leaving the slow tide to carry us upward within a hundred yards of that iron-bound coast. The water cask needed replenishing, and the tinkle of a brook enticed us to explore a cleft in the uniform barrier of the ledges. There was good depth almost to the end of a curious natural harbour, perhaps forty yards wide and a hundred yards long, the sides sheer as dock walls, the seaward rocks of the whitest quartz. Through the rest of the hot day we drifted on, humouring the light shifting airs to gain a few miles, looking with uneasy eyes at the dull bank 


\section{IN A FISHING COUNTRY}

of cloud that was ever rising higher across the whole breadth of the mighty estuary. About nine o'clock the roar of wind and rain sweeping down the river, heard afar in the stillness, gave us time to reef. We essayed to beat up into the murk, but the boat made poor weather of it with what canvas she could carry. The wind came with a steadily increasing weight; the strain of tackle and the rising sea opened the seams of the old tub, and its weeping master, encumbering the cockpit, called lamentably upon Saint after Saint for aid. Doubtless he knew his boat better than we, though to us it was clear enough she would not float till morning if held on the wind. The best way out of a bad job was to run for it, with a rag of sail, and put her ashore if the water gained. Even in this blackest night you could steer by the gleam of the surf, and, wallowing down to the Gulf before the sou'wester, suddenly we bethought us of the visibility of white rocks in the dark, and that those at the mouth of the little harbour might possibly show amid the breaking seas. The keenest eyes were stationed forward, watching as the bows rose high for some hint of a whiteness that did not fling itself into the air and dissolve. 


\section{OLD MURRAY BAY}

One handled the tiller, laying a course as close to the land as he dared, another managed the sheet, the skipper communed with the world beyond. Which of the four wrought best-praying with hands, lips, or cyes-I wot not, but just as the helmsman called 'the last wave pooped us, she won't stand much more', the lookout, heart in mouth, roared the command 'wear and run in', and the labouring yawl passed in a few seconds through the angry smother into shelter and peace. Un bel adon, as the old speech has it, for one might not look to tumble upon such luck twice in a lifetime; and Lord! what a night wind and water made of it as we lay with scarce a ripple lapping on the side.

On short cruises, as on long, it is well to keep the weather eye lifting for the signs of change. Picnic parties have often been driven to take the rough way home by land where a wind has come up against the tide, but those who use the river know that the ebb will soon draw an easterly swell off the shore, leaving a passage smooth enough for canoes. To cross the bay from cape to cape is wise only on a very settled day, for the Murray valley is the natural channel for the adjustment of atmospheric balance 


\section{IN A FISHING COUNTRY}

from the nor'westerly quadrant, and delivers the funnelled air in wicked squalls, as from a nozzle.

One is bound to dwell upon the river life, for the old Murray Bay was a watering-place, where all the world bathed and boated. The destination of a paddle might be the Rivière Loutre, or one of the streams below it; but the past generation will remember with peculiar affection the fair beaches on this side of St. Irénée: 'Smuggler's Cave', Petit Ruisseau, 'Dinner' and 'Boulder' beach, the Gros Ruisseau;--all now traversed by the railway, which shattered without ruth every familiar headland barring its path. Driftwood was there for the gathering; when evening drew in our huge fires were wont to light a sweep of sand with curving tidemarks, the row of waiting canoes, steepclimbing ranks of birch and spruce, the faces of the singers. . The reddening logs are kicked together to throw a last flame on the embarkation, the flotilla slips home under silent dip of paddles. Far astern the glow lingers, till a point shuts it out and the wharf lights twinkle ahead. I wonder if, in the days that be, aught has been devised so pleasant in the doing, so filled with 46 


\section{OLD MURRAY BAY}

happy recollection, as the beach-fire assemblies of old and young.

For seventy miles the Murray is canoeable, but only by a practised hand. I borrow from an old page:-

'We broke camp early. Half past four o'clock saw everybody yawning and shivering in the cold river-mist. By five thirty breakfast was over and the charettes were lumbering off through the woods, leaving nnly two eighteen-foot birch barks, gum with a frying-pan to melt it, and a day's rations, for we are to cover the fifty miles of water to the St. Lawrence before set of sun.

'Nicolas pilots the leading canoe; Michel, of equal skill but past the prime of his strength, follows. Little paddling will be needed, so the parson and I travel en monsieur, subject to the word of command in a pinch. The first five miles are run easily and swiftly without use of pole, then the character of the river changes as the hills draw in and the gradient steepens. Boulders are strewn thick, there is no free channel; the canoe must be eased and held, worked across stream' to dron past rocks that would tear the bottom out of her, fetched back to the course, hum- 


\section{IN A FISHING COUNTRY}

oured or thwarted at every instant. The Indians are erect in stocking-feet, keeping easy balance in the white water as the canoes answer their bidding under coercion of the pole-now but a guiding touch, then an arresting lunge with full force of arm-always sure of hold as though able to view the bottom and choose at leisure. Their art, scarcely 10) be learned without practice from boybood, is to paddling as paddling to the trundling of a wheelbarrow.

"What more irrevocable than the engagement upon a rapid! Go through you must, making quick and final choice of the best or the least bad that offers, ever with three changing points for the eye to note and the judgment to pass upon:- the immediate difficulty, the next barrier awaiting, the set of current beyond with its clue as to the likcliest side of the river below. Five times we touch--no skill could avert it - and must land to make a fire, dry and gum the leaking canoes.

'But there are miles where the pole is laid aside, where the swift flow is unbroken, and such a rapid we enter upon. Nicolas, seated on the thwart, urges the canoe forward to the rhythm of an Indian 48 


\section{OLD MURRAY BAY}

paddling song. Never before was he coaxed into singing, never since; nor is the wild chant allowed to finish. We are flying down an incline where the stream hisses through banks of gravel, and makes an abrupt turn. Swinging round the corner, a large red pine has fallen close ahead, almost across the river, which boils against it and through the jagged ends of broken branches. I hear Nicolas' C'est fini, and make ready to jump clear when we touch, but his paddle clatters on the gunwale, he springs to his feet and drives the pole through a sheer five feet of water. Strength given to few, more adroitly applied by none, arrests the canoe in the tearing current, shuddering with the strain. While yet we hang three yards from shipwreck a cry rings back to warn his old companion, and then he edges over, foot by foot, to the path of safety-every little gain in such water a feat of wonder.

'The other canoe seems to go clear, but does not quite miss the last fang of the broken tree; her side is ripped and she sinks in the pool below. No matter! All is at hand in the birch-bark's own country for patching, sewing and gumming; in an hour she is seaworthy again, and on her 


\section{IN A FISHING COUNTRY}

way. The mountains drop behind, the river sobers to an easy gait, the rapids are playthings; with the sun yet on the steeple of the old French church we slip under the bridge to the meeting of the brown water and the blue.'

These last ten miles were run many times in the season with all the canoes that could be mustered, and a stranger must sometime have stood amazed at the line of charettes carrying them inland. A string of calèches followed the fortunes of the canoemen by road, and the watchers might fairly count upon seeing 'The Teaser' temporarily dissolve the bond between some ship and its incompetent crew. The faultless performance was to go through it all without so much as grazing a rock; this was more than once managed by a gentle pilot.

The vehicles of those times were the calèche (spelled 'calash' in England two hundred years ago, and so pronounced there and in France, as in Quebec today), the quatre poteaux, and the charette. The planche was a late importation from the South Shore which supplanted the calèche, as fitter for the country roads; various types of quatre roues followed on its heels. 


\section{OLD MURRAY BAY}

Many of the roads have been improved out of knowledge. The hills on the way to the Grand Fonds, at the Petit and Gros Ruisseau, and in many other places once were really fearsome; bad as they were, people drove more often and farther. Without any complication of golf bridge and other engagements, the weather and the humour of the breakfast table were free to govern the days. Picnics were a means and not an end. You took a meal out of doors because this fell in the better with some plan; it follows that the baskets were filled with stout provender and not windy kickshaws. When the sun was shining the choice lay between the river and the road, nor was a little rain allowed to divert a purpose. The two falls on the Fraser, the Trou, St. Irénée, were not beyond reach of the walking party; or some might contrive it so as to drive one way and walk the other. An Irish 'ride and tie' agreeably relieved the shallow purse; charettes extended the effective radius of legs.

The boys did their own paddling, portaging and camp work. Camping it was, in that they pitched a moving tent and did not merely fall back upon other permanent 


\section{IN A FISHING COUNTRY}

habitations. The word 'camp', in losing the essential notion of ironsitoriness, has left the English for I should say the American) language punrer. The creation of a home in the virgin woods by one's own labour and wits has little in common with a shift to a warmed, weather-tight, furnished country-house. At some of the lakes oftenest fished there might haply be found a disreputable rulone or lean-to, but none of the dozen 'camps' within a day's journey of Murray Bay had then come into being.

Fishing was always a manstay. Every stream abounded in trout. The reward for a day of good hord work on the Loutre, the St. Irénéc, the Frascr, the Gros Ruisseau, not to mention lesser streams, would be from three tn siv dozen trout worthy of being basketed. (T remember ?4 dnzen for two rods and a half, nn the last named brook, ) and it whs the fishermon on his lone scrambles who brought first news of the waterfalls now sn well known. The lakes on the seigniories, then much more difficult of access, were frenuently visited with (and without) nermisșinn. T,ac à Gravel has vielded aond fishing for well over fifty years; but season and weather had always 


\section{OLD MURRAY BAY}

to be considered. Less than five dozen trout to a competent and persevering rod for an evening and morning was accounted poor, ten dozen good, over it unusual good sport. The fish averaged somewhat better, but for really large trout it was necessary even then to push farther afield. Rumours hearkened to by willing ears were very gad-flies which drove us to distant waters-with toils and labours which there seems no longer great stomach to encounter. But in this contrasting of past and present (with some inevitable preference) one must erer be mindful of that ancient shard, deep-buried where Babylon stood, and its cuneiform script:-'Alas, alas; times are not what they were'! The laudator's commonplace has been a safe comment for unknown cycles of the Dog Star.

By the by, and admitting the irrelevance if you press the objection, may it not be that some forgotten wag once found in this same Canicular year, covering some 1460 of our solar years, the germ of our apparently meaningless phrase,-'a dog's age'?

Whether for better or worse, the change can hardly be gainsaid. The country of mountain and lake behind Murray Bay, 


\section{IN A FISHING COUNTRY}

where the Laurentians are at their highest and wildest, is seldomer traversed and less known than it used to be. Not many adventure into it except along established trails; the spirit of exploration summons few, though countless lakes await the fly, and the prizes have not all been won. In thirty years perhaps a score have viewed the Murray's stupendous gorge, as grand as the Saguenay's and more beautiful, though it lies but a day inland. The old generation of men skilled in woodcraft and canoecraft who knew the disappearing trails, or how to travel without them, are dead or past their work; ferrying passengers to and from the Golf Club does not train their sons to pack and paddle. Even horses fit for a hard bush road cannot easily be found. The amusements that lie at hand, and a growing disposition towards luxury and easy ways, have sapped interest in a rougher and more adventurous life; yet is it hardly imaginable that the best fishing now accessible on the continent will long remain neglected. The wide areas of the Laurentide Park have much land and water unknown in detail, but the discovery of what they contain needs men, equipment, and something of a relish for hard- 


\section{OLD MURRAY BAY}

ship. May the exploitation be at the hands of sportsmen when the day arrives!

The crude beginnings of tennis go back to the 'eighties. It gave excuse for an occasional afternoon gathering; but the courts were rough, the game made little progress at first and did not much affect the tenor of life. It worked no such change in the habits of the community as did the coming of the Americans (1882), golf (1892), the insidious motor, the building of the railway.

There were occasional visitors from the south of the Line as early as 1866 . The presence of Mrs. Abraham Lincoln is remembered-still under the burden of her immense sorrow, and starting in terrified recollection at the sound of a gun. But the migration which has reached such proportions is chiefly traceable to the propaganda of a New York doctor who heard of the place through Canadian friends, visited, appreciated, and prescribed it. The little movement he set going in 1882 has become so important that, were it arrested, Pointe au Pic would shrink to less than half the size, and the shrinking would be painful, for the village and the neighbourhood have learned to depend upon the stranger 


\section{IN A FISHING COUNTRY}

for a living. A time there was when but a sixth of the houscholders were Canadians; it looked as though the remnant might disappear, but the tide turned, and the nationalities are now pretty equally divided. The American still goes 'up' to Mlurray Bay, the Canadian 'down' to it-curious the usages of these expletive prepositions! Centrifugal and centripetal forces nearly balancing, at first growth was very slow, expressed perhaps by the building of one cottage a year; of late this rate has doubled, and if the world recover normal ways the next ten years may bring as many changes as have the last fifty.

The young lady's attitude towards what is commonly esteemed a blameless regetable seems instinct with good sense, quite secure from criticism;-'I don't like spinach and I'm glad I don't like spinach for if I liked spinach I'd eat it and if I don't like it I hate it'. My attempt at a record does not question the fundamental that tastes are beyond the region of dispute... The earliest comers to the St. Lawrence shores willingly fell into accord with the simpler life which had a large part in drawing them thither. Without reluctance they discarded what did not fit the 56 


\section{OLD MURRAY BAY}

new environment, tuned themselves into harmony with unaccustomed surroundings so far as might be, attempered their minds accordingly. Those following them, unfamiliar with the prevailing spirit, laboured to reverse the process. Minds unchanging under changed skies no longer consented to be adapted; sought the adaptation of things to imported habits and likings. Which of the formulas yields most abundantly the elusive by-product, happiness, is as much or little open to debate as one's personal disposition toward spinach, but the effect is plain to see. Life has drifted into a daily round in no wise distinctive of a country village in the County of Charlevoix-pursuable elsewhere as, or more, commodiously.

Golf undeniably adds a credit item to the human balance-sheet, but there must always be an entry on the other side of the account. Demanding, and generally receiving, fullest devotion, it is jealous of all other attachments. Could one but play for amusement... Reflection discovers, lurking just beneath the surface, a series of mental, moral, and physical resemblances to alcoholism: what will not a man do in his cups-or to get into the cup! The 


\section{IN A FISHING COUNTRY}

Murray Bay Golf Club was formed on the 25 th of July, 189t, but the game had already been played for a couple of years upon rough fields behind Duberger's, and over the unbuilt-on Ridge above. In 1895 'the mound field' was leased for $\$ 20.00$ a year, and $\$ 5.00$ was the cost of a family season ticket to play thereon. The Club House went up at the end of the Butte de l'Eau-de-Vie in 1905; now all foregather there for golf, tennis, croquet, bowls, evening entertainments, meetings or tea. It is a busy hive in the heart of the season, with games arranged weeks ahead, a long list of waiting players who tee up every four minutes under the eye of a starter; - of necessity very urban and businesslike, rather unleisured and competitive for those who recall the old joys of a quiet round. In speaking of the course, I go in debt for a phrase to a New York player. Asked if Murray Bay had a really good links, his answer was slow in framing itself:- 'No... No... But... it's the best I've ever played on.'

Automobiles have flooded in-dust, smell, danger, last and worst of all the motor habit of mind, in their train. They were never built for such roads as these, 


\section{OLD MURRAY BAY}

can only pursue them in a few directions and not far enough to be worth while, cut into the charretier's trade cruelly by making the driving and riding unsafe and less desirable. As an owner was frank enough to declare:- 'A motor at Murray Bay is a dam nuisance to everybody not in it.' One is in doubt which to admire the more: the sentiment, or the exact propriety of its expression.

Church-going among Protestants has declined-not less at Murray Bay than elsewhere. The little community used to assemble itself on Sunday, and otherwise observe the day pretty faithfully. Granting, if you ask it, that the motives taking some to church are no better than those keeping others away, there remains the bald fact to register that the practice has ceased to possess the character of a civility. It has become rather more an optional matter than whether you shall play golf of a Monday. Does the disappearance of constraint count for gain or loss? I have and suggest no answer, but the achieving of a semblance of unity among Protestants was something noteworthy in a Catholic country, and courtesy at the least demands that no less happy object-lesson should distract 


\section{IN A FISHING COUNTRY}

the observances of the ancient Faith.

As to Sunday golf, one recalls Tom Morris:- 'If ye don't need a day's rest in seven, the greens do'. 'To which might be added a great authority's opinion that no man playing oftener than three times a week can hold his best form. The Club discourages Sunday play by closing the Club House and denying caddies-the latter regulation in deference to the wishes of the parish priests. Keeping the holiday (where all is holiday) would mean keener golf, better scores, and does not necessarily commit to an excess of puritanism.

The season at Murray Bay tends to become longer. Once it scarcely extended beyond July and August, when the Canadian schools were closed, and the rush of transients lasted little over a month. Now there is more of leisure, and people have found how pleasant it is to come early and linger late. A few arrive before winter has quite departed-while the trailing arbutus is yet in bloom-and are only driven away by the returning snow. Thus might they place the months in their order of choice: June, for its weather, blossoming trees and shrubs, wild flowers, the delicate and innumerable shades of green; Sep- 


\section{OLD MURRAY BAY}

tember, for sparkling days, the dying transfigurations of maple, mountain-ash, Indian pear, wild cherry; May, for all the little hints and promises in garden and wood; October, for the new-minted gold of birches and the blueberry's tongues of flamelending a fresh aspect to every hillside and even to the remote South Shore; July, the fisherman's month, for wild roses, hightide of the roadside flowers-flowing till August, ebbing till October (the tall fireweed, flaming up a whole mountain-side to gray granite and the piercing blue above, stirs the heart like the sound of a trumpet, and shall the lips be dumb?) ; August, the last, treacherous in temper, feverish of pace, dusty, thronged.

Not to see the coming and departure of the summer is to lose the best of both place and people. A grasping, unamiable side may be thrust forward in the brief season of their harvesting, when bargains must perforce be driven as to services and supplies. Early and late the native kindliness and civility have better chance to assert themselves; the higgling spirit does not shoulder these aside. They will tell you that the advent of les étrangers has not bettered their condition, has otherwise worked 


\section{IN A FISHING COUNTRY}

harm. They had little to learn in manners or morals; perhaps those who came had jittle to teach. In point of cleanliness, sanitation, respect for private property, something may have been laid to heart, but the new influences have made for extravagance, laziness, greed, discontent. It is unfortunate that a community should have to depend upon casual gleanings, and be forced to garner the last blade; with the spectacle ever before it of money lavishly spent, and (as it may seem) easily come by. Is it very sure that the virtues which appertain to another station, to wider opportunity; the evidences of gentle breeding, elaborate instruction, are always conspicuous? Country villages lying beyond reach of the stranger and his wealth show a people more self-respecting, independent, and hard-working; pursuing in happier fashion their slow evolution. May it long be so, for Quebec is the steadying ballast of a Federation that carries a deal of tophamper. A sane conservatism guards it from hysterias which run devastatingly through the other Provinces, and this conservatism has sound root in the heart of the countryman. Belief and practice are here in agreement that an enduring democracy, 


\section{OLD MURRAY BAY}

worthy the name, is only maintainable by jealously shielding every reasonable liberty of the individual; that the true measure of civic progress is the humblest citizen's sense of responsibility to the State, and the surest mark of retrogression the number and stringency of the legislative commandments imposed upon him. What corner of this unquiet earth offers in greater degree civilization's only three indispensable gifts--Justice, Security, Toleration? Shifting the nautical figure from hold to tackle, a Canadian could scarce frame a better wish than that the Dominion's sheet-anchor may not drag in coming times of storm.

Education makes steady advance. Few of the elder generation can read or write, few of the younger are unlettered. On this head I allow myself the pleasure of borrowing the opinion of an habitant, who, a penniless boy, fought for a little reading writing and ciphering, with what happily accompanies these in Quebec, a schooling in manners and morals. For that wider education of which culture, the faculty of detachment, a toleration of differing views and of those holding them are the ripest fruits, he had nothing but admiration. His doubts concerned what lies between 


\section{IN A FISHING COUNTRY}

the remote extremes; pervades that broad region where knowledge, falling short of wisdom, serves but to stiffen prejudice, teaches neither sympathy nor humility, breeds a cocksureness that some tiny fraction is the whole truth. Montaigne, of this day no less than his own, insists on being cited-but had not he and my friend, each by his own road, attained what they were envying?-'The simple peasants are good people, and so are the philosophers: men of strong and clear reason, and whose souls are enriched with an ample instruciion of profitable sciences. The Mongrels who have disdained the first form of ignorance of letters, and have not been able to attain to the other (sitting betwixt two) stools, as I, and a great many more of us do) are dangerous, foolish, and importunate; these are they that trouble the world'.

Of the old life at Murray Bay, little then remains. Few come to boat, bathe, drive, ride, walk, out of love for the people, or to rid themaclves awhile of the coils of convention (from which Americans break reluctantly) and yet the press of visitors ever insrenses. Wherein lies the secret?

Much is unchanged, unspoiled. Hill and river are as they were in the begin- 


\section{OLD MURRAY BAY}

ning; the speech gives a foreign touch, lifting the mind out of its routine (discreditably to the bilingual Canadian, the American comes better equipped for the interchange); friendships, often international, grown fast and firm with the years, are pleasantly renewed; you have the novelty of being in a country where the acquiring of a postage stamp is attended with a 'please' and a 'thank you'-if the manners of the purchaser run to it; there is a sense of being within the fringe of mighty forests, at the edge of a wilderness without boundary; and the native breath of the place is so rare a commingling of sea and mountain air that the like is hardly to be found elsewhere.

Seeking a comparison, the east coast of Scotland comes nearest, but the westerly and northerly winds of the British Isles lack the sparkle and briskness, nor have they blown through illimitable evergreen woods. At depth in the Gulf of St. Lawrence the temperature of the water is $31^{\circ}$; although warming at the surface near Murray Bay to $42^{\circ}-58^{\circ}$, it remains cool enough to temper every breeze from N. E. to S. W. Only true westerly winds, rare and shortlived, 


\section{IN A FISHING COUNTRY}

may bring uncomfortable heat. The river stabilizes the temperature in summer and winter, but only along its shores. A different isothermal line runs a few miles inland, as vegetation rain and snowf all prove, and the common experience of meeting anfother climate in half an hour's drive. When Pointe au Pic is chilly, Ste. Agnès may be sweltering. Changes come very swiftly. A breeze from the river, when the thermometer is in the eighties, will send it down faster than a degree a minute to $60^{\circ}$, or below-once, as I remember, from $86^{\circ}$ to $46^{\circ}$ in a quarter of an hour.

Murray Bay is in truth the battle ground of two types of weather, the Continental and the Gulf; the season's character depending upon which gains the mastery. Speaking broadly, there are for the habitant but the two winds-the rent d'en haut and the rent d'en bas. The latter, the illomened nord-est, covering the N. E. and S. E. quadrants, brings rain, tempest, cold. The former is, without fine distinction. from any other quarter and means good weather, present or to come. Clear gales from the north-east are not quite unknown, with a sharp salt tang, straight from the arctic current and the ice; but generally 66 


\section{OLD MURRAY BAY}

the nord-est is a shallow in-draught towards an approaching area of low pressure which will probably find its easiest path down the lakes and the St. Lawrence. You may see the low clouds hurrying the other way. I have watched the migratory fisheating gulls, then tarrying in the bay till the lakes should be free of ice, spend the afternoon between the two currents; now sailing up with a full nor'easterly gale, now rising through air-eddies-where I suppose no aeroplane could live-to be swept back on the mighty wings of the sou'wester. Either it was the superbest coasting that living creatures might enjoy, or they were minded to escape from a temperature of $42^{\circ}$ to agreeable warmth aloft. Buffeted by the chilly blast, we envied them. Tradition gives the nord-est three days to blow itself out, but it may fall short of this, or take a new lease of life. A rising glass announces and accompanies it; no change is to be looked for till a falling barometer shows the approach of the depression, with its sequence of shifting winds by the south. If the wind goes the other way about 'Trust it not, for back 'twill run.'

Commenting upon the underlying 


\section{IN A FISHING COUNTRY}

causes for this, Sir Napier Shaw says:'One of the intriguing mysteries about air currents is the difference of their behaviour when they have to pass one another. If they use the British rule of the road and keep to the left, they pass one another amicably, an anticyclonic area is set up, and the finest of fine weather reigns between; it is the result of that dispensation that we (in England) have been enjoying all the summer (of 1921). But when the currents pass one another according to the Continental rule of the road and "keep to the right," no sooner do they come within range than they curl themselves up into all sorts of violent contortions and the worst of weather is the result.'

Of the familiar weather signs such as 'Evening red and morning gray etc.' some are especially relied upon at Murray Bay:

Pluie arant sept heures, beau temps avant onze heures.

Arc-en-ciel du soir met le beau temps en l'air;

Arc-en-ciel du matin met le mauvais temps dans le chemin.

But your evening rainbow is distrusted if it 'fishes in the sea'! 


\section{OLD MURRAY BAY}

Vivid and unusual colours in the sky are of bad augury.

Should sun or moon be 'wrapt in a gauzy veil', you may prophetically chant:-

Blow wind from the south,

Blow mud in the mouth

$$
\text { of Jane, Jane, Jane. }
$$

When the nor'west wind fails to blow out clear, we say il a manqué son coup, and are aware that further trouble is to be looked for instead of the three or four fine days it should bring.

A burning sun presages rain.

Ciel pommelé, fille fardée, N'ont point longue durée.

More to the point, perhaps, to set down a few weather saws that have something of a peculiar and local application.

When the South Shore looms unduly near, and you can see every farm-house and barn fifteen miles away as though magnified by a glass, the unwholesome clearness is due to invisible vapour that is likely soon to condense in rain. This state of the atmosphere is not to be confounded with the dry pellucidity of fine weather which makes the outlines of 69 


\section{IN A FISHING COUNTRY}

Rivière du Loup church plain to the naked eye at thirty miles, and gives a sharp horizon of seventy miles from the heights above Cap à l'Aigle.

When the ear catches the whistle of a very distant steamer it is a tell-tale of moisture in excess.

Mirage down the river, lifting Hare Island, Hare Island Reef and the shore below in bold cliffs to the sky, foreruns the north-east wind.

So long as the wrack of a nor'easterly storm keeps drifting up the bay and into the valley, the clear-up is not yet.

Sea-breezes by day, a land-breeze in the evening, reveal the atmosphere in just balance; any variation in these normal winds, the reverse.

A dewless night, clouds that dazzle with their whiteness or move in two directions, portend change.

When the sky is partly overcast, and the cheminées between the clouds are closing, there will be showers; otherwise when these are opening.

Thunderstorms sweep down the Murray valley upon Cap à l'Aigle from a high serrated ridge of granite with a knob like an old woman's cap. When the habitant sees 


\section{OLD MURRAY BAY}

dark clouds massing behind it he says:la bonne femme Charlotte se fâche, il va mouiller.

Those curious, sometimes dangerous, little whirlwinds called sorciers are born when still and sultry air breaks through a cooler layer confining it; this state of tension will not be relieved without some violent commotion.

When snow first lies upon the Cap à l'Aigle hills expect winter in a month.

A Good Friday nord-est endures for forty days!

All but the last are sound and useful rules of thumb, worthy of being taken into account by the amateur forecaster along with his readings as to pressure, temperature and humidity.

When you talk of the weather with a countryman, boldly or shyly he will soon draw the moon into the discussion. Doubts of her power he has none, and he is ingen:ous in covering her shortcomings with his charity.

North wind is looked for after a play of northern lights, and generally you will have it. At any time during the summer the clairons may appear, not seldom with the brilliancy and colour of winter auroras. In 


\section{IN A FISHING COUNTRY}

the same week of 1917 two displays befell which our fathers would have held portents of the passing of many strong souls in battle. The sky was blotched in every quarter as with seeping blood that darkened, paled, cozed afresh in horrid stains during the space of an hour. 'Fearful lights' they were in those days of dread, dismaying the spirit, awakening no sense of beauty. Strangely different the other, and no less awesome. The north was ink-black, but immense ragged clouds of white light arose in the north-east, drove across the sky, sank below the opposite horizon. Passing swiftly as the amazed eye could follow them, under impulse as it seemed of some mighty wind, they wanly illuminated the river's whole expanse, for an instant lit the dark hills, and then the impenetrable curtain of the night fell blank and sudden.

If pardon should be prayed for lingering over the theme of Murray Bay's weather, it is bespoken for the part this has played in drawing people thither: air indescribably fresh and stimulating, the assurance of coolness when all the west and south wilts and gasps; these gifts, with the river and the everlasting hills, no meddling hand may spoil. 


\section{OLD MURRAY BAY}

But young and old, the late comer and he whose memory dwells upon the past-as each may esteem what things belong to his happiness-will gather severally and arrange the nosegay of his praise.

Compellingly strong the charm, distilled from many and diverse elements, that impels one of the busiest of men, on setting an unwilling foot in New York, straightway to begin marking off the tedious procession of days that must pass before his return-that holds some families faithful unto the fifth generation-reunites others from the ends of the earth-forgives immoderateness in the parody:

What are fifty years of Europe To a summer at Malbaie?

-adds such heartiness to greetings, so much of poignancy to farewells-that moved one, too sensitive, I dare say, to the tears of things, thus to write of Closing the House:

'They have gone away by twos and threes. Groups making pretence of gaiety have stood upon the steamer's deck answering song with song, cheer with cheer, and as the distance widened, signal by signal. 


\section{IN A FISHING COUNTRY}

'Solitary ones have departed in the night - so silently that the empty chair at breakfast first tells us of their absence. 'Close up the ranks! Shorten the table!

A glass for the dead already, And lurrah for the next that dies!

'The break-up is here, summer is over.

'And so comes the day when the house that has known so many care-free hours must be deserted. For the last time your footstep sounds in the darkened place. The very door-handles seem loth to leave your grasp; the chairs extend their arms for an uncouth good-bye. You shut and bar the door through which the breeze has wandered at will all the long summer days. The clang hurts like an unkindness done to a creature suffering mutely, helplessly, at your hands.

'For surely these familiar walls have in them some sentiency-else how could they look such melancholy farewells...

'In the white desolateness of winter will not imprisoned echoes of laughter and music come forth-the very ghosts of sounds.

'From the eaves the rain drips heavily, the cedars are clothed in mist. 


\section{OLD MURRAY BAY}

'To what dirge-like measure do you tread, while the house, half-hidden in the trees, watches reproachfully your departure.

'The mist thickens-how it blurs everything!' 

LAC EMMURAILLÉ 



\section{LAC EMMURAILLÊ}

Had a wounded moose not taken the long slope to a mountain top, this little water, like many another in the Laurentides Park, might still be unknown and nameless. A last bullet brought him to earth just where the steep descent, heavily timbered wherever slides of rock have spared it, falls some hundreds of feet to the $W$ alled Lake. But the aptly descriptive name, there and then bestowed by the pursuing hunter, will hardly serve for identification in a land where peculiarities of form or setting, incidents of the chase, the grateful recollection of some pancake or cherished demijohn, again and again are thus commemorated.

Easier access than by the moose's climbing trail was soon discovered. Lac Emmuraillé may well have lain there solitary since the last ice-age fashioned a bed for it, but no more than ten minutes of easy ascent through well-grown birches actually divides it from a larger lake, along the further shore of which passes the only road through the mountains.

Beside this untravelled highway lives 


\section{IN A FISHING COUNTRY}

Michel the long year round, except when the affairs of his guardianship take him to some corner of the broad tract under his charge, and save for rare visits to his family thirty miles down the road. Two or three days of village life, and he was always restive to return. If the Government has many servants as faithful, honest and competent, it is to be exceedingly congratulated.* A friend and close companion shares the tidy log-cabin, is never second in his thoughts, and throws a willing hundred and fifty pounds of bone and muscle into the traces of the traineau when Michel breaks his way across snowy mountain and lake. To come upon terms of acquaintance with such a dog, to be accepted as one of his master's guests, is a privilege; nor, speaking with a little outburst of candour, do the unhappy creatures which town life and human selfishness condemn to pampered futility profit by contrast:--what things their dog-souls worshipped stolen away, and such sorry gods offered them in lieu!

*. Wavhe I shnuld change the tense, for Michel has lived: but while there is rememhrance of many a hapry day in which he hore part. Yichel is yet of the present to those who knew him... Extreme fatigues and killing exposure, upon inurneys in the puhlic service which he persisted in undertaking. cut him down hefore his years were full. 


\section{LAC EMMURAILLÉ}

Michel is content with these solitudes, for they give unfailing employment to alert eye and eager mind. Nothing that comes within the range of his senses slips by unnoticed; facts are fitted neatly into their places, upon the sum of them his hypotheses are framed, clean deductions follow in their turn. Albeit he could scarcely spell out the words 'formal and inductive logic', and the labour of doing it would be vain, his reasoning does not fail to observe the canons.

Though irrelevant here, I am tempted to speak of something which befell him not many winters ago- a bit of luck to be envied by anyone who has held a rifle. Approaching a lake through the deep woods, and hearing a great ado, he quickened pace without abating caution. When he arrived, noiselessly and under shelter, the tragedy was before his eyes-a hundred yards out upon the ice. A caribou had just been pulled down by thirteen of the huge timber-wolves; they tore at the dying animal and fought with one another in a welter of leaping bodies and snapping jaws. A Winchester was in his hand, a box of cartridges in his pocket. Kicking off his snowshoes-a woodsman never has to untie 81 


\section{IN A FISHING COUNTRY}

them--in a moment he was seated on one, with plenty of ammunition conveniently at his elbow upon the other. A point-blank fusillade opened in to the brown of the pack, continuing, with sights that were gradually raised, so long as a wolf was left to shoot at. For six pates, with ears to match, the bounty was $\$ 90.00$; but the real measure of his satisfaction was the chastisement he had managed to inflict upon these blood-thirsty creatures who slaughter the helpless caribou-often in mere lust of killing. It was a great stroke of fortune, and surely an unlucky dinner-table for the thirteen, for not one of the convives got off scot-free.

It was entirely natural that Michel should study Lac Emmuraillé from a fisherman's point of view-all the more so because the lower lake contains those rare and beautiful Arctic charr which are probably identified as salvelinus nitidus; but though his visits were many and the times favourable, he saw nothing break the surface, and was driven to conclude that the water was barren. This opinion was confirmed by long and careful fishing from a canoe in 1914. One is casily deceived in such a quest unless the conditions be taken into account. I have cast by the hour, 


\section{LAC EMMURAILLÉ}

with keenness brought to the sharpest edge by a pressing need for food, over waters well stocked with free-rising trout, and failed to move a single fish. Very pertinent is it therefore to record that these attempts were made towards the end of June, during the hatch of the may-fly, with both air and water in perfect trim, when not only fontinalis, but all the Salmonidae, are looking out for the natural fly and will show interest in the artificial one. (It will be understood that this time varies with latitude and elevation.)

In 1913 Michel had committed ten small trout to the lake, but in the following year there was no response from them. The presence of many may-flies upon the surface, dead and alive, argued strongly for the absence of fish. Other ephemera and water-insects were numerous and apparently undisturbed. Apart from the bountiful provision of this kind of food, the lake did not commend itself as a home for trout. Not much beyond a third of a mile long, and an eighth of a mile broad, the only shallows, at either end, were of small area. Malloch, in his admirable book on salmon and trout, says of Scottish lochs at sea-level that all water over eleven feet in depth is 


\section{IN A FISHING COUNTRY}

negligible as a source of food, for light and heat penetrate no farther in such degree as to engender animal and vegetable life. In clearer water, and with our fiercer suns, the rule may be different, but the altitude of 2200 feet must also be taken in to account. The lake deepens rapidly on both sides to twenty feet or more. The tiny stream which feeds it tumbles in abruptly, and the décharge falls over an old beaver dam, so that small trout would be without the usual sanctuaries. A talus of boulders, breaking the line of encircling forest for fifty or sixty yards, gives the only spot whence a line can be thrown from the shore. This seemed a likely place for trout to lie, and of it more anon.

Rather doubting it worth while, we resolved to make an attempt at stocking the water. Fish caught in the lake below were kept alive in a landing-net trailing overboard, transferred to a tin pail, and rushed across the portage. All but a few were able to swim away into a world which they found very strange and new, judging by their fearfulness and hesitation.

A word is needed as to the lineage of these hundred trout, areraging perhaps onc third of a pound. Their ancestors, to the 84 


\section{LAC EMMURAILLÉ}

number of a hundred and fifty-two, made a longer and more uncomfortable journey from the Murray River to the lower lakethen supposed to be absolutely fishless-in 1909. (The experiment was wholly of Michel's designing, and he carried it through single-handed.) They were the trout characteristic of the rapids of that river, underfed and lean, running about six to the pound, dark in colour, white- or yellow- fleshed, brilliantly spotted; recklessly greedy, but without the stamina of well-conditioned fish. In his original environment it may be that each of them had as much chance of prospering and growing great as a farmer has of becoming a millionaire, or a private soldier a general. The struggle for a bare existence was fierce and continual; larger trout menaced them if they dared to invade deeper waters. In the present state of knowledge, their agetwo, ten or fifty years-seems to be a matter of guess-work. Plainly they were victims of the Malthusian law that population tends to increase beyond the means of subsistence. Translation to a new state bettered things marvellously for them; although, to their surprise and ours, it turned out that they had to dispute pos- 


\section{IN A FISHING COUNTRY}

session with an ancient and vigorous, if less adaptable, race. At first the trout kept themselves strictly apart, upon their own side of the lake; but in the course of a few years some sort of relations were established with the first-comers, not, I fear, to the advantage of the latter. There is some ground for suspecting cross-breeding, and the less agreeable fact must be mentioned that once a fontinalis was taken with a nitidus half-way down his throat. The unaggressive nitidus are rapidly diminishing in numbers, and it looks as though they would not survive; but it is the fortunes of the fontinalis, and at the moment of those in the lower lake, that concern us here.

The hundred and fifty-two appear to have lived, almost to a fish. By 1912 they had grown and altered their appearance beyond recognition. Averaging well over the pound, very uniform in size, they were lighter in colour, pink of flesh, fat, lusty, well-shaped and of great staying-power. Every one of them might have served as a painter's model, and the killing of a dozen in the course of an evening was more to a fisherman's taste than some fabulous basket of less dashing and courageous fish. 1913 brought them up to two pounds. In 1914, 86 


\section{LAC EMMURAILLÉ}

the largest caught was within a fraction of three pounds, and he was indeed a handful. By 1915 they had multiplied exceedingly, few of the original lot were left, the average began to fall, but the fish were still in fine condition. One change of habit was observed. Whereas in the beginning they ran down the décharge at the spawningtime and completely deserted the lake in September, they now spawned in any corner that suited them. At this time population and the means of subsistence were balancing very nicely. Had it been possible to maintain this equilibrium, the fishing would have remained as perfect as man could desire, but such is not the way of nature. No angler was at hand in 1916 to throw his weight into the scale, which, by 1917 , had tipped decisively under free operation of the Malthusian law. 1918 saw the average fall still lower to a bare three-fourths of a pound, while a trout of a pound and a half became a prize. Furthermore, there was a detectable loss of vigour and fighting quality. Nine years in a lake supplying an unusual plenty of food, without any restriction on increase, completed the cycle. The trout were now numerous beyond the point of being able 


\section{IN A FISHING COUNTRY}

to find adequate maintenance. The wheel had come full circle.

This observed sequence seems to have a bearing on the question whether or no these waters contain two species of trout,one capable, the other incapable, of growing to a large size. The native fishermen answer it in the affirmative, but I am not aware that biologists give any support to their universal belief. Your gaffsmen will assert, even in the case of very small fish, that this one is of the race des grosses, and that of the race des petites, but they are not in perfect agreement as to the indicative signs to which they point. The hundred and fifty-two transplanted trout were not all of the race des grosses, according to Michel, yet all grew evenly and rapidly, and we are yet to hear some instructive word of their descendants.

A thoughtful and experienced fisherman of these parts holds the opinion that certain members of one and the same family can become une race dégénêrée: in our case we may have been observing this very process. Where natural conditions prevail in a given water over a length of time, the trout rise or fall to a size from which there is little variation. In the absence of 88 


\section{LAC EMMURAILLÉ}

any disturbing factor an exact balance is bound to establish itself between the total weight of trout and the sum of available food. However much the fisherman might prefer that this total weight should be divided into a few large units, rather than many small ones, nature orders it otherwise, unless she is thwarted, and trout degenerate to the standard which fits with their habitat. Our inability to discover why degeneration proceeds further in one lake or stream than another-multiplying the units at the expense of weight-rests upon the impossibility of ascertaining the whole of the facts which control a fish's existence. Shifting to the converse aspect of the question, there seems no reason to doubt that all degenerates are capable of rapid and indefinite improvement in a better environment. It follows that you cannot command good results from stocking an indifferent water with some exceptionally fine breed of fish, and that, when the water is suitable, little is gained by selecting the stock.

But nothing in the above helps to explain how it comes about that in most rivers, and in a few lakes, some trout emerge from their fellows, to attain great size. Cannibalism offers the only clue that sug- 


\section{IN A FISHING COUNTRY}

gests itself; but how, and why, among coequals, is the bent acquired? Is every trout a potential cannibal? Is the ill-fed failure in life merely deficient in native vigour? Does he say, contemplating his murder ous brother:- 'But for the grace of circumstance there go I ?' Fain would I hand over the problem to any who can throw light upon it.

Malloch gives two methods of redressing such a situation as we encountered,severe fishing, or a curtailment of the spawning-beds. The latter being impossible, we attempted the former. As fish cannot be thrown away, someone may enquire what we did with the many hundred trout which could not be used on the spot. They were smoked: now a lightly-smoked trout will keep for weeks, is of high merit upon the breakfast-table, as entrée or savoury, in the homely fish-pie. The procedure is quite simple: Remove the head, split down the back, clean with as little washing as possible, salt with a free hand, and lay out to dry for a few sunny hours. Make your smoke of punky aspen or poplar, (Indians will use nothing else where these are to be had), hang the fish in couples by the tail, well above the smudge. Twenty-four hours 


\section{LAC EMMURAILLE}

of thorough smoking ensures them for ten days; forty-eight hours, and they will be safe for a month. Keep them strictly dry, away from flies, and in an airy place (say, a potato sack hung in an attic). The packing must be careful to avoid breakage in carrying. It is scarcely worth while to bother with anything under half a pound; though small trout, well smoked but uncooked, are toothsome as a red herring. A few planks make a convenient boucanerie, --six feet high, and not less than four feet by two in the other dimensions. Weatherproof, it must be, with two openings that can be shut tightly,- - the upper one to admit the fish, which depend from cross-bars, the lower for tending the fire. An improvisation, answering quite tolerably, may be built of birch-bark, or even spruce boughs.

Before inviting you to cross the portage from the lower to the upper lake, I take leave to say a word about the annual perplexity which confronts us. The best of the fishing for trout, and all the fishing for nitidus, depend upon the advent of the mayfly, and this date varies, according to season, by two or three weeks. To hit off the time one must guess when the may-fly is 91 


\section{IN A FISHING COUNTRY}

likely to appear. Following such indications as temperature and vegetation afford, we have sometimes found ourselves early or late. Michel, at length, supplicd the key. He observed that the may-fly (the manne) is due when the water-lily rises to the surface, and, further, that the waterlily appears about a month after the breakup of the ice. The Spring of 1917 was late, after a hard winter (in those parts) with a heavy snowfall. The may-fly, commonly expected about June 25 th, did not arrive until July 10th. Trees and flowers were making their normal display, in weather that was warm and fine; but from June 27 th to July 4 th we watched in vain for the may-fly-there was no complaint as to a deficiency of other flies-and were compelled to depart without seeing the rise of a single nitidus. Terrestrial conditions, then, are misleading; the length of time which must elapse before the winged manna comes to the birth is not under the immediate control of air or sun; we have to descend to the sub-aqueous region if we would discover the moment when the beginnings of animal and vegetable growth become possible. The disappearance of the ice would 


\section{LAC EMMURAILLÉ}

seem to be the safest point of departure for the calculation.

Shift the scene to Lac Emmuraillé, where it shall remain. We have here a fishless lake, before the ten small trout of 1913 were released; - the fate of these unknown; - a hundred more convoyed across in 1914. Attentive fishing in the following year, when the weather was not unfavourable, brought nothing to the surface; but the undiscouraged Michel, continuing his visits, was able to report in 1916 that he had seen large trout rising at the natural fly.

How did we fail in 1915 to discover the presence of these fish? It may be that transplanted trout are reluctant to rise--having some memory of the fly that hurt and exiled them-but this I doubt. In the case in hand it seems much more likely that every need being amply supplied in the depths they could afford to neglect other sustenance. This suggests a view as to the primitive habits of the brook trout, - habits to which they would easily and rapidly revert on occasion. Is it not probable that trout are bottom-feeders by nature, and only become surface-feeders by force of circumstance? Not a few Laurentian lakes contain very large fish to which 


\section{IN A FISHING COUNTRY}

the fly offers no attraction. One has been accustomed to think that such trout, abiding continually below, were exceptions somehow driven into an abnormal way of life. But perhaps these are only carrying on the true tradition-still alive in the race's bundle of instincts and ready to reassert itself when the chance offers. I do not delay to test the theory, but it will be found to throw light upon a good many questions.

The laggard sun of 1917 had not cleared away the snowdrifts by the 23rd of June; catkins still were clinging, tamaracks were prinked in the faintest tracery of green, Labrador tea was yet in hard close bud, only the Indian pear was shaking out its ragged blooms. On a chilly drizzly afternoon we stood on the shore of the Walled I ake with that slender stock of hope which survives every discouragement. An hour slipped away-two hours-in slow, painstaking circuits of the lake. If a trout there was with any thought of rising, we sought to offer the fly he had in mind; meanwhile the rain worked inward, and the raw air numbed hands and wrists till our casting became wooden and lifeless. Loth to go while daylight lasted, we landed on the 94 


\section{LAC EMMURAILLÉ}

boulders I have mentioned, to make a fire. Sitting back to back in the canoe, there had been no chance to observe how melancholy was the countenance of my friend, how depressingly the water coursed down his chilled beak, upon which the inclement air had bestowed a strange diversity of colouring. As we laboured with wet wood and dripping birch-bark to kindle a blaze, Michel asked leave to borrow a rod, and while the fire was yet struggling to flame, some exclamation from him turned us to see with amazement the rod bent butt to tip. We were not likely to grudge first blood in recompense for so much of patience and zeal. The fish made a determined endeavour to involve himself and the cast among submerged boulders; this manoeuvre cleverly defeated, he sought with heavy rushes to gain the open water, but, tiring quickly, was led to the net with unexpected ease. If not too proud, he was too fat to fight.

According to Dr. Ellis's table, his length (twenty inches and a half) did not entitle him by nearly three-quarters of a pound to the four and a half pounds that the scale awarded, but the girth (thirteen and a half inches) accounted for it. This table 


\section{IN A FISHING COUNTRY}

deduces the weight of Nepigon trout up to five and a quarter pounds from their length, and is doubtless reliable for that river; but girth varies greatly in different waters, particularly with large fish, and must be reckoned as a factor if the estimate is to approach accuracy. At best you can only reach an approximation - as any one may discover by applying the formulas. *

Nothing endears the Celt so much to us as his resiliency, - his swift leaps from profundities of gloom to a radiancy of joy. I have intimated that my companion,-upon whom, is an honest fisherman, God surely did not scamp his handiwork,-betrayed some discontent with the rain and the cold and the lack of sport. When a landing on the boulders was proposed, there dropped from him the remark:- 'That's the san-

* The Ellis equation:-

$$
\mathrm{WV}=\frac{\mathrm{L} \text {. } 3}{2285}
$$

In erpation from the Fishing (iasette:- $\mathbb{W}=\frac{\left(\mathrm{L}+\frac{1}{\mathrm{~L}}\right) \times \mathrm{G}}{1000}$

One from a friend's note-book:-

$$
\mathrm{W}=\frac{\mathrm{L} \times \mathrm{G}_{2}}{800}
$$

The seand and thirel formulas give this fish more than four and a half pounds. They both yield results quite absurdly excessive in the case of brook trout above six pounds in weight, but it is fair to say that they are calculated for the brown tront. 


\section{LAC EMMURAILLÉ}

guinary use? Let's go home. Can't you see there's not a deleted fish in the incarnadine lake?' I judge that-what with thirst, hunger, wetness and discouragement -he was then approaching his emotional nadir. The lake having vindicated itself with first-fruits so worthy, the hour being late, with other and better days to follow, I threw out a suggestion that we should now depart. 'Go home!'- -he snorted scorn and contempt upon me for a weakling; 'Go home, forsooth! - when the place is fairly stiff with big trout asking to be caught!' Rebounding in one soaring flight to the zenith, behold him attack the lake again with ardour and fresh hope, full of the burning faith which commands success, and rewarded presently by a fish that towed him hither and thither with transfigured face, the battle-light shining in his eyes. This was altogether a livelier and more difficult fellow than the first, though he proved to weigh half a pound less. There was so end of trouble in getting him to face the hateful net, but at length the two lay side by side in the canoe, as handsome a couple as one could ask to see.

The next five days made a well-beaten path of the faint trail to Lac Emmuraillé. 


\section{IN A FISHING COUNTRY}

It became the fashion to run across, early or late, 'just for a cast or two'; but if these fish have set habits of feeding on the surface, we were unable to determine them. At times unpredictable they rose; to stop again as unexpectedly. There were hours when they appeared to be on the move throughout the whole lake, and other like hours when not a fish was stirring; no one surprised the golden moment which brought them freely to the fly. The pursuit of these whimsical, capricious trout did not cease to fascinate, however many the disappointments. When a universal rise on the lower lake seemed evidence of conditions that must be favourable everywhere, the Emmuraillé trout gave no sign; journeys over the portage which there was nothing in wind or weather to invite, were often successful.

In the end everyone scored, and had moreover his story to tell of a heavy fish that broke him after some minutes of dogged contest, generally at the end of a long and uncontrollable rush. The difference between the largest and the smallest of the half-dozen killed was but three-quarters of a pound, and the average weight was a 


\section{LAC EMMURAILLÉ}

trifle over four pounds. In length and girth there was a remarkable uniformity: all within a fraction of twenty and thirteen inches.

Never a small trout was seen, and this calls for remark. The fish must spawn, (one female with well-developed roe was taken) but either the eggs have no chance to mature because the small and shallow spawning-beds freeze, or the fry can find no place of refuge. While this is hard upon the rising generation, it leaves the fisherman able to control the head of fish that the water is to carry. Lakes which provide ample food, but deny multiplication of the species, are very particularly worth the angler's attention.

We have seen that three years gave the deported trout of 1914 a twelve-fold increase in weight, for, if any of the 1913 batch survived, it is incredible that our catch was confined to these; the alterations in appearance and in disposition were no less remarkable than the growth. At two removes from the river, the Emmuraille fish were so unlike their eager, starveling parents in colour, shape, flesh and habits, that anyone not sure of the fact would certainly have denied the ancestry. Almost 


\section{IN A FISHING COUNTRY}

hump-backed in outline-for in rapid development length never keeps pace with girth-the intestines were cased in fat, and they were incomparably better on the table. In habit, lazy and incalculable, surface-food was nearly indifferent to them-an occasional dainty to be indulged in upon the whim. They found too easy a living, under an inverted Malthusianism, and the cure was that they should be given a sharper taste of the rigours of existence. We were groping our way, however, and drafted no more than thirty-six small fish from the lower lake.

The season of 1918 proved that we had not gone far enough. A late spring followed a winter that no one is likely to forget; the water was cold and continual rains kept it at a high level. Lac Emmuraillé was fished in brilliant nor'-westerly weather; with a squally north wind; till nine o'clock on a dull evening; in a wet, sou'westerly gale; on clear and overcast mornings; but at no time with great success. Though a fair number of trout were sometimes about the surface, they showed little interest in the natural fly or its imitation. The Parmacheene Belle-a lure and not a fly, for it counterfeits the ventral fin of a 100 


\section{LAC EMMURAILLÉ}

small fish-was received very lukewarmly; this made it pretty clear that the colonists had not adopted, or had opportunity for cannibalism. A school of ten, lying in shallow water, seemed intent upon other affairs; whether intent or merely inert there was no move towards the fly. Mayflies hatched freely; fluttered upon the water; perished unregarded. The fish could afford to neglect what is so eagerly appreciated elsewhere; a glance at the untidy surface of the lake made this apparent, as did also the inordinate fatness of the trout killed. Subsistence still out-running population, we sought to bring about a juster balance by putting in sixty-four fish able to hold their own - of about half a pound in weight.

It was an unlucky trip, otherwise than in the matter of weather. One fish that was unquestionably very heavy, smashed a good rod and got away. Several pulled out through sheer and prolonged strain. Only four were brought to net, and of these a trout of one and three-eighth pounds was credited to the 1917 lot (an increase of a pound in the year). The others averaged practically four pounds.

A rather singular pursuit and capture 101 


\section{IN A FISHING COUNTRY}

was creditable to the fisherman and shows the unusual nature of the fishing. On a day of such stillness that distant movements could be discerned, a little disturbance in the very middle of the lake seemed worth investigating, and, as the canoe stealthily approached the spot, a pair of large trout were seen to be playing on the surface, not apparently feeding, with back fins out of water. A long line, straight and true, dropped the flies some feet short of them. One sank quietly; the other came forward in the most leisurely way, passed the Parmacheene Belle on the tail of the cast without making a motion towards it, followed the slowly-retreating Yellow May, and closed his jaws upon it with heart-breaking deliberation, at the last possible instant. Then he woke up! Only a man practised in dealing with listless half-persuaded salmon, would have held the mean betwixt slackening and quickening the pace. A breathless spectator admired the art which kept the fly just barely alive until the fish came up with it and took his slow resolve.

The good Izaac reminds us that no man yet lost that which he never had, but he does not discourage a little reasonable 102 


\section{LAC EMMURAILLÉ}

speculation as to the size of the departed. It were unkindly done (supposing the possibility) that one should snatch away a measurable portion of bread and butter from those poor fellows to whom every estimate of a 'lost' fish is (professionally) another instance of paranoic delusion or common honest lying; but a sober word, uttered in this private way, should not hurt their trade. The old hand is not apt to be far astray in the opinion he forms from the rise, the swirl, the behaviour and play, the feel of his rod; and we had little doubt that the lake held greater trout than any we had killed. There was a case in which fairly convincing proof was forthcoming. A standard of comparison was fresh to the eyes of both the witnesses, for a fivepounder, perfect in shape and condition, (length twenty-three inches, girth thirteen and a quarter inches) had just been brought in from another water. Both the actors had long experience in the judging of trout above that weight. In gale and rain a fish was hooked of great vigour and of unusual disposition. Taking line as he willed, at the end of two mad runs he leaped high out of the water-the second time more than his own length straight into the air-shaking 


\section{IN A FISHING COUNTRY}

his head, bass-like, in rage at the fly. After ten minutes of a furious struggle, in which he was never spared for an instant, he won freedom, the hook tore out, and the fisherman charges himself with undue severity of method toward so heavy a fish. Equally he might have had to blame himself, using a gentler hand; but, whichever the winning tactics, there was excellent opportunity for appraisal in all the three dimensions, and both the observers assert that beyond a peradventure the lake holds at least one trout of the six-pound class.

Lac Emmuraille is ceiled with ice, the birches toss their stark branches in the north wind, the snows lie heavy on the spruces, deep upon the trail; but memory and hope may travel to its shores undeterred by winter storms, in the weather of unchanging springtime. 
THE QUÊTEUX 



\section{THE QUETTEUX}

WiTh thirty miles of forest and mountain between us and les paroisses, a tap at the door, even a gentle deprecatory tap, was as unexpected and startling as would have been the rumble of an earthquake; but there was nothing to disquiet one in the small bowed figure that entered. From the very edge of his chair, as though ready to depart at any slight hint of displeasure, he watched us with the eyes of a child who has met uncomprehended fates-in his glance something of a hare's wildness, of a chipmunk's simple cunning.

A little alms he sought, in that he was not able to work. Surely the old chemineau (quêteux in the country speech) made choice of a strange beat in those thirty leagues of lonely road between Chicoutimi and the St. Lawrence. Thither had he drifted from Chicago ten years before, nor is he home-sick for its clamorous windy streets.

But was the choice so strange? Along these rough miles of forest, with but half a dozen dwellings scattered over sixty of 


\section{IN A FISHING COTNTRY}

them, there is no call to pray:-

Christ look upon us in this city, And keep our sympathy and pity Fresh, and our faces heavenward; Lest we grow hard.

The poorest never deny a dole and a lodging to the wanderer:- not in the canny spirit which throws the sprat of charity to land eternal reward:- nor yet under coercion of the belief,-

If meate or drinke thou gavest nane,

The fire shall burn thee to the bare bane...

but only because such acts are casiest and very natural to them.

So the old beggarman goes his round, and likely will cross and re-cross the mountains in spring and autumn till an untimely storm, earlier or later than his reckoning, weaves for him a winding-sheet.

Sixty-five years ago Switzerland gave him breath, and taught him French, Italian, German. Chicago added English; he speaks and reads the four languages. Every printed scrap he chances upon is gathered up and treasured, against his winter retreat. Haunted by a great dread of fire, he rings round with stones his every smudge or blaze, and, departing, quenches the last spark. Smoking, his hands are close about 


\section{THE QUÊTEUX}

the pipe lest a coal escape. A strange apparition is he thus upon the road, with hands clasped over the bowl of his pipe and a rag draping his ears.

At twenty-five he made a fortune-two thousand francs - scraped together in a long bout of labour as a journeyman-printer in Paris. The earning of so vast a sum cancelled his debt to the world till the end of time, yet did his wealth soon take wings in the land of gold across the sea. Bare of everything, he tramped northward and eastward to another Eldorado where social economics do not stay the giving hand, and want is never so far away that the bitter pinch of it passes out of mind. Here he is received, even welcomed; for he renders little services, bears messages, passes on the gossip, finds something in his store to return for entertainment. Against his truthfulness and his honesty no word is said. All the coppers and silver that come his way are hoarded, and by the time snows are lying ton thick upon the road for feeble legs to compass long marches, he has laid in his winter provision. In quantity-according to his gleanings- the staples vary, but not in kind-flour, rice, fat, tea, sugar. With these he withdraws to some deserted 109 


\section{IN A FISHING COUNTRY}

logging-shanty, and does not appear again until the earth shows bare; last year his hibernation was from December lst to April 15th. Two passing chasseurs exchanged words with him, but this was the only invasion of his peace; their visit seemed neither welcome nor unwelcome.

He does not fish or trap; but sleeps, eats, mends the fire, reads his scraps of newspaper and thinks his long thoughts,-concerning what in earth or heaven? Have they brought him nearer the Secret? What answer have his solitudes returned to the question,-

Is there naught in the Heaven above us

Whence the hail and the levin are hurled,

But the wind that is borne around us

By the rush of the rolling world?

The wind that shall scatter my ashes,

And bear me to silence and sleep,

With the dirge, and the sound of lamenting,

And voices of women who weep.

. For him, nor dirge, nor women's tears, nor any lamentable cry. 


\section{PROVING THE RULE}





\section{PROVING THE RULE.}

Before and during the rain, fishes swim near the surface and rise more than usual.

AfTer ten days of the finest August weather the morning broke fair, but the wind was shifting uneasily in the southerly quadrants; a veil of high cirrus drew slowly across the sky which passed with the hours from deep to paler shades of blue, through pearls and grays, to a leaden sameness. Rain was in the air, and it would be welcome and much to our purpose; for hath not old Izaac written,- 'if he hit to make his fly right, and have the luck to hit, also, where there is store of Trouts, a dark day, and a right wind, he will catch such store of them as will encourage him...' Certain it was that we should find the water in the river both low and warm, and reason assured us that the fish would be seeking the conlness of springs and lesser streams, where they would need but rain to stir them into activity. There the big ones, free to pick and choose, were bound to be assembled, -neither glutted with food, nor lying too deep to see the fly,- their eyes alert for 


\section{IN A FISHING COUNTRY}

movement on the surface, not yet preoccupied with the cares of spawning, happily awaiting fulfilment of the promise of the skies.

To pick up a couple weighing three and a half and two pounds on our eight mile walk to La Roche, seemed of happy augury. What might we not expect from the less-fished waters of the main river when this uncertain tributary behaved so handsomely? To every appearance, in a belief that was both confident and unanimous, fortune had for once ordained that our long journey was to end at the precise ichthyological moment an all-wise fisherman would have chosen or contrived for himself. So we foresaw it: not thus did it befall.

Such threat the clouds were holding that it was almost a surprise to arrive unwetted. Only was it after dunnage had been unpacked, provisions stowed, blankets served out, lunch disposed of and fishing stations allotted, that a gentle benignant rain began to dull the quiet ripple. The hours left to us of so perfect an afternoon must surely add a notable page of entries to the logbook!

Favourite spots were first attacked with 114 


\section{PROVING THE RULE}

customary flies, and, as time wore on, with a variety of creations, ranging from the tiniest of black gnats to freaks that suggested in size and plumage the toucan or the macaw. Unlikely places were visited. Everywhere the fly-book's furniture met with the same treatment,--not fastidious rejection, but the blankest indifference. There was no forcing ourselves upon the notice of these fish. It is true that someone was half persuaded he had seen a great trout move, but this was the beginning of it, and the end.

Slipping in the natural human way from error to error, we began to think that all these efforts were being wasted upon water temporarily barren. Dead it looked: dead as a roadside puddle. Mysteriously, the big trout were otherwhere. Even from the exceeding multitude of lesser ones, usually taken here at pleasure, it was not easy to secure a few dozens for the frying-pan.

Throughout these disappointing hours the rain was steadily becoming heavier. When the failing light made it plain that the jig was up, and dripping figures, stiffly arising from canoes, showed intimate touch with waters other than those that be above the firmament, the low-hung sky abandoned 


\section{IN A FISHING COUNTRY}

pretence of being freighted only with summer showers. Our universe narrowed to a few gray yards of wetness. A long crescendo reached the climax that one knows for a few seconds at the height of a thunderstorm, but the fortissimo passage continued for the better part of an hoursounding on the roof like the roll of a dozen kettle-drums. We had to shout to be heard through the din.

It seemed as though Nature must exhaust herself in so furious an nutburst, but the slow diminuendo to such rain as we associate for some odd reason with cats and dogs was followed by another crescendo to a roaring culmination. 'Bucketfuls' was no figure of speech, for the water seemed thrown in masses rather than falling in drops, forcing a way on all sides into the tight little cabin. Every hollow in the gravelly snil about us instantly brimmed and nverran. Thus, again and again, hour after hour, throughout the night and until the next midday, were the heavens opened in thunderous downpour; then the storm began to drizzle away, in manner as it had begun.

What more natural (to one statistically afflicted) than the attempt at estimating 116 


\section{PROVING THE RULE}

so prodigious a rainfall? Two inches an hour is not beyond experience in temperate latitudes; there had been many hours of this so-called 'cloud-burst', half a day of exceedingly heavy rain upon the top of it, and not a moment's pause throughout the twenty-four hours. Our guess at a fall of ten inches erred, I am pretty sure, on the side of defect. (The conditions were local, but the weather-map, afterwards examined, does not deny the possibility.)

Consider what ten inches of water means : -1000 tons to the acre; 640,000 tons to the square mile. Reckoning the catchment-basin above us at 300 square miles, here were $192,000,000$ tons of surplus water which the river must hurry past our door. Heap it upon a single acre, and your foursquare column mounts thirty miles into the sky.

All day the river rose; the rapid above us, no more than whispering yesterday, was now hoarse with mad rage; rock after rock, island after island, drowned before our eyes in the red swirling current where before had stretched a peaceful dead-water.

One strange little drama unrolled itself as we looked across the flood. A mother loon with two chicks, washed from their 


\section{IN A FISHING COUN'TRY}

nest in some quiet reach, were swept past us. The little ones were almost spent with their wild passage through a mile of tempestuous rapid, but, notwithstanding the fatigue and distress that were so evident, the mother pushed steadily on, her children following as best they might. Yet was she mindful of them, for in calmer water she stopped and looked back,-summoning them, we fancied. The chicks caught up to her and vanished; not for a little while were we able to discover the fledgelings on her comfortable back where they crouched and clung as she steered her way to safety and a new home. I imagine that few have had the pleasure of chancing on such a sight; one of us found some dusty memory in the lumber-room of his mind; two woodsmen of very wide experience, appealed to afterwards, declared that they had heard une histoire semblable racontée beside some camp-fire of their youth, and another keen observer asserted that he once had seen an instance of this motherly care.

There seemed no likelihood of raising anything in a discoloured torrent where the fly would not be visible to a fish lying six inches below the surface; yet a trout of two and three-quarter pounds was taken that 118 


\section{PROVING THE RULE}

afternoon above what had hitherto borne firm repute as dry land, far beyond the river's usual bounds. The task of saving this lively fellow, in a cover of marsh grass dwarf birch and blueberry bushes, was no trifling one; but more admirable than his skill were the faith and pertinacity that sustained the fisherman in so unpromising a chase.

Not until nine o'clock on the morning of the third day did the water cease rising. It was then above the usual marks of spring flood, when the ice breaks up and the deep winter snows are hurried away. That the height of the rise might be fixed as nearly as possible, we set off to find our Nilometer-la grosse roche. A word as to this boulder upon which the accident of position has bestowed an importance out of all proportion to its size. At the distance of a cast from it is a well known haunt of the great trout. The stone marks an auspicious spot where the eddy meets the current and a cold stream flows in; where depth, bottom and feeding are precisely what these exacting inhabitants of the river demand. From the days of earliest tradition-Indian, French, English-and throughout historic times, 


\section{IN A FISHING COUNTRY}

here was always good fishing were the trout in the mood, and, whether in the mood or no, there was assurance that your line was falling over something worth your while. Fishermen dropped into the way of passing on word of their luck à ras la grosse roche; so came it about that this inconsiderable boulder was exalted above the host of its fellows; became the rock, and gave, as prestige widened, the name La Roche to a favoured pool, a bend in the river, the neighbouring country-side.

At this time of year, from six to twentyfour inches are commonly above water. Anything less or more would be accounted unusual, and the twenty inches that was showing on our arrival announced a propitious level from a fishing point of view. After twenty minutes of sounding and groping with a paddle, the grosse roche was found under three and a half feet of water; so the river was up sixty-two inches at a place where it is nearly 300 yards wide.

But why all this dull particularity of fact and figure about rain in the skies, or rushing to the sea? The object is to give a willing reader an even start with ourselves in thinking out the cause of the fishes' strange inaction-perhaps in reaching our 


\section{PROVING THE RULE}

conclusion that they were sensible of, and governed by, this impending cataclysm. We foresaw the approach of nothing extraordinary, for the barometer had little to say; and deemed the lines pleasantly apposite:-

Through the clear stream the fishes rise, And nimbly catch th' incautious flies.

They were governed by the exception; not the rule. Something beyond the common was about to unsettle the course of their lives. No light matter was it, this invasion of forty billion gallons of water. What has been told, and remains to tell, convinced us that the fish we had laboured over so vainly were under the imperative control of a sense we lack, or, at least, have lost the art of using.

Foreknowledge, foresight, weather-wisdom, may be misleading words to describe this sense; importing, as they do, mental processes scarcely to be ascribed to fishes. Perhaps the anticipation of on-coming disaster pushed normal instincts into the background; more probably the weather conditions directly induced a physical lethargy profound enough to make them insensible to any ordinary stimulus. But some may prefer to believe that the Father of all the Fishes, him whom in tireless hope we 


\section{IN A FISHING COUNTRY}

pursue from youth to old age, promulgated out of the depths of his ancient wisdom so imperative a storm-warning, that none but a few reckless fingerings dared to set it at naught.

If memory is to be trusted, Herodotus, in the course of some disparaging remarks about a city of his travels, ascribes to the people of this place the surpassing hebetude of not knowing enough to come in out of the rain. Most of us in this superior century recognize rain when it is actually falling upon us, and are wont to defend ourselves against it by such means as lie at hand, but this we esteem a sufficiency of weather-knowledge.

Civilization has more or less atrophied a sense which informs or controls birds, beasts, insects and fish; the remnant left to us is little regarded, but still introduces an odd disturbing factor into our lives. Where blunders are recorded and tabulated, as in some banking-houses, the graph of error curves upward before and during bad weather. A comprehensive chart of mankind's mental and physical activities would reveal aberrations explicable only with the aid of metenrology. A new study this, of many utilities, deserving cultivation. 122 


\section{PROVING THE RULE}

How comfortable to be able to fall back upon a barogram, or a hygrometric reading, rather than one's native idiocy, when convicted of a tactless remark, or a revoke at Bridge!

But the human race is able to advance its claim a little further; for there are those among us privileged to carry with them the trustworthy weather-glasses of rheumatic joints, old wounds, corns, heads that ache and nerves that jangle,-all functioning very usefully upon occasion. It occurs to one that the possession of such qualifications ought to cut a figure in the selection of our professional weatherprophets. Delicate instruments might be devised for measuring the extent of their inconveniences and the readings would be of the utmost help in local prediction. On the other hand, as it must be admitted, a change of personnel would introduce rather desperate confusion until equations were adjusted, it being improbable that any two sets of corns are tuned to an identical response. Better, on the whole, to enlist the more delicate sensibilities of the lower orders in nature. A scientifically-stocked zoological garden could not fail to assist the deliberations of a weather bureau 


\section{IN A FISHING COUNTRY}

where, for example, some touch-and-go prognostic respecting non-isobaric rain was in the balance.

For a man of the fields will tell you that before rain or unsettled weather the ruminant animals crowd together and seek sheltered places; dogs become drowsy and stupid, cats sneeze, birds of long flight stay about home and fly low, cocks crow early and late, ducks and geese continually plunge and wash themselves, carthworms appear, spiders do not build their usual web, (should they work during rain it will not last long) flies in their diversity of species bite, sting and crawl, the ass brays loudly and often, sheep bleat much in the evening, pigs run hither and thither before wind, (hence, doubtless, the saying that pigs see the wind) loons call, the whitethroat (rain-bird) sings often by day and by night, peacocks scream, black birds are noisy and woodpeckers very active, crows fly solitarily to their clamorous congregations, finches chirp persistently, frogs croak and toads walk with legs extended; - a list which anyone may add to at his pleasure.

Conversely, when none of these things happen, we may know the sky is not big 124 


\section{PROVING THE RULE}

with real mischief; and, furthermore, we have the positive guidance of many fairweather signs:-cheerful songs from highperched robins, crows flying in pairs, the frequent hooting of owls by night, shimmering spider webs on the grass, long seaward or lakeward flights of gulls, distant journeyings of the bee.

Before the barometer moves, sometimes before the heavens give us their earliest warning, creatures higher in this particular scale are declaring by action or inaction that some influence is working upon them. Did we preserve a like responsiveness; had we not drilled ourselves to walk within the parallels of convention, to repress every show of feeling, our separate and collective demonstrations might be no less striking. How lively and interesting a spectacle, if little groups of us might be seen running up and down, all eyes to wind'ard, like pigs viewing an approaching gale! But life never gains in amenity without some correlative loss.

If Golf Clubs continue to flourish, in an altered world, I suggest that Greens Committees should add to their duties the keeping of hens. Not sophisticated, pampered 


\section{IN A FISHING COUNTRY}

hens, but such as are taught to seek their meat from God. Within modest but very useful limits, your hen is amazingly weather-wise. Though of mean intellectual capacity, she still has room in her head for two ideas. The clash between them develops her meteorological value. Food she must have, but she yearns most consumedly to keep dry; and it is given her to know how the future bears on ambitions that are possibly inconsistent. When it rains, and is going to clear, sheltering, she bides her time; but if, disregardful of the rain, she pecks draggledly through it, you may put away your clubs and go home. Where the weather is hopeless, extreme discomfort is preferred before starvation. How convenient to utilize these wits of hers on a dubious day! 'Steward' you telephone the club, 'is it raining?' 'Yes, Sir.' 'Are the hens out?' No, sir.' And you make your way thither, to find the sun shining.

But even a hen cannot peer very far into the future, and I doubt whether any other beast or bird is greatly wiser. When they make response to on-coming weather that is of a lasting type, they may appear to be foreshadowing more than the immediate 


\section{PROVING THE RULE}

event. They get credit for being aware, not merely of impending change, but of stable conditions, which the change will introduce. Perhaps experience tells them that a certain kind of weather, when it arrives, will tend to persist; however this may be, their actions point to what lies some distance ahead, and are accepted as guides by farmer and fisherman. Thus, the high and early flights of mosquitohawks are associated with 'set-fair', while crows, swallows, ducks and sea-fowl demean themselves in distinctive unmistakable ways when a bout of good weather, or bad, is on the road. Two things are to be said: there is no evidence of knowledge extending beyond the next atmospheric move; man is able to achieve as reliable prognostics by reasoning upon the facts.

Were it possible to extend the range of forecasts, and perhaps to determine the character of a whole season by the behaviour of those creatures to whom heat, cold, wind and rain are matters of profoundest concern, it is sure that all knowledge on this head would long ago have been assembled and co-ordinated. And this in fact has been attempted. Out of respect for the deep and universal faith in prophe- 


\section{IN A FISHING COUNTRY}

cies based on the thickness of the beaver's lodge, or muskrat's house, the bones of the wild goose, the squirrel's hoard, bird migrations, the annual experiment of groundhog and bear, learned men were set by the Government at WTashington to investigate. Their interesting report discloses just 'a grain of truth amid the rubbish. It shows how birds, beasts, fishes, insects, make frequent and egregious mistakes which lead them to disaster. Migrations are of ten too early or too late, with the result in either case that many perish. The loon is of the first authority on all that pertains to water, but the mother loon I wrote of did not build beyond reach of flood, and I have observed the hard case of yet another, compelled by falling water to abandon nest and eggs. None can boast infallible instinct or foreknowledge. All blunder at one time or another, and, blundering, pay the penalty.

Where then is the grain of truth to be found? Only in application of the factundoubted, though little understood-that like tends to breed meteorological like. Contrary to the opinion which scems to prevail, probabilities favour the persistence of that type of weather with which, 128 


\section{PROVING THE RULE}

at the moment, we may be blessed or cursed. Heat, cold, rain, blue skies or cloudy, are likelier to be followed by their kind than their opposites. The winter that sets in early lasts long, and the cold is severe. When the autumn is warm, and lingers late, you may look for a mild winter. A great depth of snow is apt to draw a wet summer in its train.

Meteorology does not traffic in certainties; errors attend day by day predictions, and the chances of mistake increase in high ratio as events become remoter, but this habit of the weather asserts itself with sufficient constancy to give rise to expectations of measurable value. Make a test, if you will, by remarking the sequels of recent winters and summers.

We pay too great compliment to muskrat and squirrel, if we credit them with a foresight which they turn intelligently to account. An easier hypothesis satisfies the facts. Fur and feather thicken, hoards are gathered, houses strengthened against the frost, precisely when the need arises, and not till then. The hard winter is soon upon us, and its first breath sets all these natural processes a-going; so do they extend over a longer time, with larger results. The 


\section{IN A FISHING COUNTRY}

squirrel is well prepared against the lean months, because, heedfully beginning to gather his store when the warning comes, he has better opportunity to make it ample. Like other creatures he but follows nature's immediate promptings, and often, but not always, is he right.

Man may draw deductions from these things, should he choose to reason from effect rather than cause, but he gains nothing thereby, for the sources of the squirrel's knowledge are likewise open to him. His prophecy has precisely the same value as though he founded it upon the date when a neighbour dons his woollen socks.

Possibly experience may have informed the squirrel of this trend of the weather towards stability--'law', one may scarcely call it-but neither man nor squirrel is able to go much further.

The general character of our seasons depends upon the permanency of the continental anticyclone. This is believed to be governed by the Pacific winds, which are controlled by the Pacific currents. These, in turn, are dominated by the trade-winds. Beyond the trade-winds lies, at present, a blank wall. If the squirrel sees through it, his instinct has a marvellous length of 130 


\section{PROVING THE RULE}

reach across time and space. Shrewd guesses there have been as to the ultimate causes, and the clue which would raise longrange predictions nearly to the level of accuracy of the shorter ones now serving us so well seems nearly within grasp.

People who assert:- 'we have had so much rain that it will surely be fine tomorrow', believe that they have the law of average on their side, but in weather or cards it is only averages over a long period upon which we can rely. There is not the least assurance that a very bad will be followed by a very good hand, or a foul day by a fair one. In cards, the chances against any one of all possible deals are ever alike; in weather, another factor turns the odds against the popular view, and supplies us with a rule of thumb that goes a little way towards restoring the credit of the groundhog as weather-prophet.

When the cold sunshine of Candlemas day outlines his shadow upon the snow, anticyclonic conditions nearly always prevail, and, prevailing, are likely to continue. Should the sky be overcast it is equally probable, though in neither case certain, that the immense refrigerator which regulates our winter temperature is dissipated, 


\section{IN A FISHING COUNTRY}

or has retreated northward, and we shall remain under southerly influences. Bear and ground-hog govern themselves by what they encounter, and, if it be cold, have the good sense to go back to bed. This small degree of prescience some of us share with them. It is unlikely that they reason from former experiences-in our manner-as to the persistence of cyclonic and anticyclonic types.

In Quebec it is an article of faith that two months precisely after the migrating crows first scratch in the roads, spring will arrive,-genial weather, fit for sowing. In 1918 les anciens noted this date: March 15th. On May 14th, snow-flurries; on May 15 th, spring in full tide. Small wonder that the first remark of the day, after Bonjour, was Les corneilles étaient pas mal corrects,-des oiseaux bien intelligents. This neat bit of work will secure their reputation for many a long year!

On St. Swithin's day it rains. When weather of the rainy type holds sway in high summer, you may look for more of it. I should be sorry to deny St. Patrick, St. Swithin, St. Martin or any other Saint the smallest of his perquisites, but the rationalistic view is that the day before or after his 


\section{PROVING THE RULE}

Feast would supply an indication of equal value. Of course, what happens on a red-letter day is better noted and remembered. We recall a Christmas storm, but could not for the life of us tell whether it snowed on the 2tth or 26th. Beyond reasonable question there are certain groups of critical days throughout the year, and the presence or absence then of seasonable characteristics is a basis for quite respectable forecasts.

Man's habit has ever been to minister to the barren vanity of the moon (Stevenson's phrase, I think). At this moment my future crop of as yet unplanted potatoes is taking sad chance of autumn frosts; because it would savour of impiety in this County to commit the patates to earth before the moon entered her second quarter.

On how exiguous a foundation rests her fame as mistress of the skies and of vegetation! She attends punctually to her tidal duties, and the tides add local emphasis to the weather; at the full she has some power of dissipating cloud, (this is doubted now) but her changes have no more meteorological consequence than the periodicities of Jupiter's seven (or is it eight) satellites 


\section{IN A FISHING COUNTRY}

As someone jingles it:-

The moon and the weather

May change together;

But change of the moon

Does not change the weather.

If we'd no moon at all,

And that may seem strange,

We still would have weather

That's subject to change.

Like the ground-hog, and much in the same way, she gives a little encouragement to her votaries; for happen it must in the nature of things that her phases, and the weather's shifts, sometimes fall together. Moreover when she comes in fair, or the reverse, the chances of the type persisting are in her favour. More cannot be conceded, and this observations and records put beyond doubt; but we are altogether likely to hand on, for yet a few generations, the little trinity of persistent errors concerning the rule of the fickle moon, the streaky-bacon theory of weather, the gift to birds and beasts of piercing deep into the future.

Little danger there is indeed of shattering these illusions:- or the other pleasant fancies that a beneficent Gulf Stream laves the British Isles; the equinoxes are beset with storms; intelligence, and not the very lack of it, makes of the horse the useful beast he is; theoretical beliefs control 


\section{PROVING THE RULE}

human action; the will operates mysteriously in racuo; women possess an intuitive faculty denied to man. And perhaps it is best to hold on to all the dear familiar deceptions until the last grip parts:-

To save a mayd, St. George the Dragon slew,

- A pretty tale, if all is told be true;

Some say there are no Dragons, and 'tis said

There was no George; pray God there was a mayd!

It is part of the woodsman's creed that trout rise best when the moon is waxing. This may be so, but I have no evidence to offer in support. Occasional attempts at fishing by moonlight have met with very moderate success; as to there being a relation between the stage of the moon and the disposition of trout towards the fly, my vote in a jury-box would be for the verdict 'not proven'. I suggest that this is another lingering vestige of the beliefs, once universal, so plentifully recorded in $T h$ ? Golden Bough. - 'Men in ancient and modern times have deduced (from the supposed influence of this goddess or fetich) a whole code of rules for the guidance of the husbandman, the shepherd, and others.' 'The moon in her increase, full growth, and in her wane are the emblems of a rising, flourishing, and declining fortune.' All business of importance should be set on foot between the new moon and the full. 


\section{IN A FISHING COUNTRY}

Thus you may hope to increase your goods; furthermore, the adoption of proper measures when the moon is waning will diminish your ills. But as to application of the principles there is unhappily a lack of unanimity. Even the land of kultur is distracted by opposing views on a subject of so much general importance as the removal of warts. One school holds with the formula;-'As the moon decreases, so may my pains decrease also.' Another;'What I see waxes; what I touch, let it vanish away.' They are of one mind, however, with respect to what follows the incantation: you must cross yourself thrice, go home without speaking to anyone, and repeat three paternosters behind the kitchen door. Doubts even more regrettable exist as to the most auspicious phase of the moon for the expelling of devils. In another department of the moon's activities, there are those who contend that all seed should be sown while she strengthens, if it is to receive proper assistance in its growth (this is our view in Charlevoix, except in the case of buckwheat which would run to flower rather than grain under so excessive a stimulation) but a large body of respectable authority favours the planting of root- 


\section{PROVING THE RULE}

crops after the full,-pointing out, and with much reason, that things growing darkly below ground must profit most in the dark of the moon. Sailors and Indians are divided in opinion as to whether the horns of the crescent should be pointing upwards or dorwnwards at the beginning of a dry month, and they give such convincing reasons for this view and the other that one is constrained to leave the question open.

In truth, the deity whose awful dictates imperilled Marathon, and were the undoing of the Athenians before Syracuse, has fallen upon evil days, and cuts a small figure as arbiter of our destinies. It is much if we nod to her new face over the left shoulder, or turn the silver in our pockets; the beliefs that her phases control the weather, or dictate the times to sow and to fish, are the last sorry relics of the esteem in which she was anciently held by the credulous sons of men.

Credulous! Perhaps we do but change our fetiches. In the fourth year of the Great War, it was my privilege to hear a New York drummer expound his views upon a cognate matter in the Pullman smoker. If he were not up to date, I miss 


\section{IN A FISHING COUNTRY}

the yuality of the phrase; also, I judged him representative of his day and calling. He made revelation to us of certain rules of conduct from which nothing would persuade him to depart. When about to engage upon a really big deal, not 'for a thousand dollars' would he draw on his left sock first. Furthermore, if through haste or fumbling his underclothing became fastened crookedly, so must it remain,even had he to endure all day the inconvenient pressure on his stomach (saving your presence) of the misplaced button. Neglect of these precautions would, he was persuaded, ruin any negotiation; (observance of them had constantly brought him rich reward. They were the tap-root of a personal success so great that all his modesty failed to conceal it from us. He lavished proof in chapters and verses. Abolit the button he came near to a distressing realism. Perhaps he has a following in this cult; certainly had he insisted upon the imprudence of walking under a ladder, failing to touch wood, or paring one's nails on a Friday, not a few men of sense would have been found to agree with him.

One can only indulge the hope that the reader, by a powerful effort of memory, 


\section{PROVING THE RULE}

will be able to recall the situation upon our river which has provoked a digression past praying for. As the water slowly subsided, the theory put forward to account for our ill-success was to receive confirmation. It became apparent that the trout were far more affected by the threat than the event, by anticipation than actuality. At the very height of the flood, when to fish seemed quite absurd, a brace of three pounds, and a little under three, was killed far inland. One thing made for us. The great rain was comfortably warm and no cool weather followed upon it; wherefore the river, dropping in the space of a week to high summer level, and clearing to a rich brown amber, remained always of favourable temperature.

The first day of falling water yielded us fish of five, three and a quarter, three, and two and a half pounds; and the next four days filled the smoke-house with trout, weighing at least the pound which gave them privilege of record. One of five and a half pounds, the best our scales showed, was gaffed by the hand. This safe manner of landing a good fish may not be familiar to everyone-useful when you are without a net and cannot beach. Trout 


\section{IN A FISHING COUNTRY}

are not alamed by slow movements or a light touch, especially when the water is deep. Lead your tired fish alongside canoe or rock, drop the hand rery guietly upon his back and slip it with exceeding gentleness up to the grill, cluse on him guickly and firmly, digging in the thumb, and so lift him out. You will lose fewer big fellows in this manner than a clumsy gaffer will rob you of; but let there be extreme deliberation in every motion of hand and body till the instant comes for the swift unflinching grasp and swing.

Some fish got away in the heavy water, about which private opinions were-still may be-entertained; but regret is clean out of place, for such is the stuff of which are woven the keenest memories, the liveliest hopes.

On a propitious day we account four or five great trout no mean reward; we bettered this under conditions that seemed impossible. Though the fish were dispersed to remote and unexpected places, they were eager to take the fly wherever it cruld be seen upon the turbulent deeplytinged water. Their apprehensions were at an end; the deluge had done its worst. the flood was abating, they had survived 


\section{PROVING THE RULE}

the calamity. As their world was spared to them, life might go on as before, and food be taken in a thankful spirit.

One uncommon entertainment they afforded us when the river was still far over the top of the grosse roche. The whole thing had an air as though the Father of the Fishes had proclaimed a General Thanksgiving for mercies recently vouchsafed, for there was a rejoicing such as not one of us had ever assisted at. The big fellows were merry-making; rising heads and tails, disporting themselves upon the surface in boisterous play, leaping from the water again and again like clean-run salmon coming up from the sea. The memorable display was only ended by rainsqualls of the fiercest, and resounding thunder. 

THE RIVER 



\section{THE RIVER}

The little story is not mine, unhappily the words are. I wish you could have it as it came, smelling of the Flanders soil, from one sick and wearying for home.

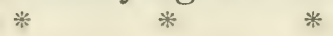

A quiet evening, as evenings went in the firing-line, with a soft southerly wind, and rain at the back of it.

Captain Bruce put his head into a dugout where two subalterns of the Canadian regiment to which he was attached were resuming an oft-interrupted game of chess. - 'Stenson, MacDougal, this is Major Bartlet,-over with your last contingent, and sent up here to see how we live in the pleasant land of Flanders.'

'Come in, Captain; glad to see you, Major. What's the best word from our Lady of the Snows? - excuse the shortcomings of our ménage in the matter of furniture. pray take a biscuit-box.'

The new comer reviews with a discerning eye the little dodges that made life endurable in the small damp cave.

'Not exactly the Ritz, but I've slept in worse, and hope to again.' 


\section{IN A FISHING COUNTRY}

'Perhaps with something a bit more amusing in prospect than the slaying of Huns,' said MacDougal.

'That goes without saying; one does not shiver a wet night through under the lee of a spruce for the mere love of being uncomfortable.'

'O, the woods!-that's different. I, George MacDougal, once a godly and peaceable stockbroker, now an indifferent soldier, declare to Heaven that the thought of a sapin bed in the rain makes me homesick. Mighty odd, isn't it? One doesn't think like that about Montreal. Montreal is well enough in its way: probably I'll end my days there, if I don't stop here; but 'home' seems to lie out beyond-up in the hills, where the rivers rise, and we blazed the trails. Somehow, when you're over here, that's Canada;-that's what you want to get back to. Why, this afternoon I saw the ripple on a pond-had the feel of fishing weather-caught myself looking to see if the trout were rising-been thinking of the river ever since.'

Bartlet nodded; his eyes followed MacDougal's westward, through the clay wall: - The river! - saw it last on an evening like this. Warm, a light breeze, rain in 


\section{THE RIVER}

the air. Big trout rolling up where you could barely get the fly out to them...'

MacDougal caught the word. Their antiphony went without pause, the others listening:

'Off the mouth of the cold stream, wasn't it,- -where the water deepens beyond the lily pads?'

'Yes! Yes! just where the eddy circling round the bay meets the current alongside the big boulder.'

'The sound of the rapid kept swinging toward you and away again, like the swell of an organ opening and closing.'

'The jack-pines on the sky-line showed every little tuft against the green light in the north-west.'

'And the shadows were creeping up the deadwater till you couldn't tell where the river ended and the woods began.'

'Mosquito hawks wheeled and dived, and a white-throat sang $\mathrm{O}$-Canada-CanadaCanada from the last twig of a balsam.'

'How keen good old Michel was as he netted the fish!--Elles mordent à soir, il faut bien les prendre quand elles sont de bonne humeur.'

'I remember... and that huge old chap cruising about, who made the threepounders look like minnows.' 


\section{IN A FISHING COUNTRY}

'He's waiting there yet; and another like him-seven-eight-nine pounds, under the fall, at the end of the long trail across the caribou-barrens.'

'When the river's at the right pitch we'll run down to the lower pools-over the slow white clouds buried a mile under the canoe.'

'Can you hear the water part at her bows? Doesn't she lift when you let your shoulders into the paddle!'

'I say, isn't it all clean and sweet andafter this-this...'

'Sorry to break in on your reminiscences, Bartlet, but I told the C. O. that MacDougal would take you on in ten minutes. Hope you'll both see your river again. Good-bye, and don't forget you aren't there now...'

* * * *

'Didn't know, Stenson, that MacDougal and Bartlet were pals.'

'Don't think they ever saw one another before,-Bartlet's a Western man.'

'What about this river of theirs? Seems a first rate sort of place. Like to fish it when I go out to Canada. Where is it?

'God knows!-I guess it's . . . O well ... just-The River.' 
JACK - O' - LANTERN 



\section{JACK - O' - LANTERN}

An old man saw a vision, a young man dreamed a dream: so did they depart into the wilderness to seek in vain, and yet to find great content; for chill failure is not in the missing of the quarry, but in losing delight of the chase. This blackest day dawns late or never at all for the fisherman. His spirit fares out adventurously from the fireside to waters remoter than any his flies have touched; the old dog at his feet whimpers and twitches in courses more daring than ever he ran. Stiff of limb and short of breath, disdaining to profit by experience, they dash hopefully after elusive things, showing but a decent surprise, a brief pretence of regret, when their sparrows take to wing. What perishes not in realization has its place forever among the treasures incorruptible by moth and rust. And so it is not alone those rare pages recording success we love to turn, over which we linger. One of the many days which no red-letter distinguishes, perchance may set a-dancing for you some ancient Will-o'-the-wisp to lead you again, unreluctant, through swamp and tangle. 


\section{IN A FISHING COUNTRY}

Already buried fifty miles deep in the Laurentian hills, sheltered from flies and lying soft o' nights, with fishing on all sides to satisfy any son of man, what beckoned these two onward? Will the phantom consent to appear before you with compelling finger? If not, mine the unskilful conjuring, or yours a wiser, unenvied, incredulity.

These many years; on the Jacques Cartier, the Montmorenci, the Murray; in little lakes tucked away distantly among the Charlevoix mountains; wherever great trout leaped for us, fought and were subdued; when the six- the seven- the eightpounders were being weighed, admired, discussed; always was there hovering in the background a tradition of something longer, deeper, heavier ...

'A grand trout that, Thomas.'

'Magnifique!'

'Such fish are rare.'

'Très rares.'

'These waters can hardly show anything better?'

'It happens not often; as for me, but once have I seen... and back would we drift to an October five and twenty years before, 


\section{JACK-O'-LANTERN}

and the two lakes he chanced upon in his old trapping days.

You who have not acquaintance are entitled to be assured that Thomas knows whereof he speaks and speaks the thing he knows--eyes and tongue trustworthy instruments to observe and to testify.

Two lakes (so his story ran) and beside the larger was encamped a Montagnais family. The children, fishing on the spawning beds, were taking many long, active, light-coloured trout-bleues in his descriptive word-running to three and four pounds. Beautiful to look at, these were very strong and of a surprising courage. Thus did the Lake of the Long Blue Ones take hold of imagination, insistently summoning.

But the Lake of the Fat Red Ones, nearby the other, was the destroyer of our peace. Here Thomas' mortal gaze had fallen upon a pair of incredible trout, lying in plain view at the mouth of a little stream, with back fins out of water. The length did not awe him so much as the broadness of their backs, and their amazing depth. This he was wont to indicate with the breadth of his two hands, no entreaty for moderation ever inducing him to 


\section{IN A FISHING COUNTRY}

leave out the thumbs. Pressed as to weight, he preferred to supply these unvarying dimensions and allow us to work the formulas:-

'You have your figures, and are able to calculate better than I.'

'Nine pounds? - Ten pounds?'

'Au moins, peut être plus.'

If you are sensible of the growing reproach we felt until the tradition should be run to earth you will ask why, at the first hearing, we did not fly to these virgin waters. Could one indeed but fly! A hundred less likely things have happened than that this should become the accepted way of going a-fishing, but for us who still must swink and sweat across the world's irregular cumbered surface, the first step of all was to clear the trail for a canoe. Little can be done from the shore of a lake; a raft of green timber is a poor ship, tedious to make and ill to navigate; nothing like a fair trial could be had without portaging the amphibious craft through some leagues of forest. Also the attack must be duly timed, for only twice in the year is it likely that the large brook trout of the lakes will concern themselves with surface foodduring the hatch of the may-fly, or when 


\section{JACK-O'LANTERN}

they move into shallow water to spawn.

The planets were not in happy conjunction till 19--, when the last navigable water and the Lake of the Long Blue Ones were linked together by a chemin débarrassé. A comfortable sort of road it sounds, this chemin débarrassé, but all the consideration it shows is for the canoe. Such growth is cut, and only that, which would block its passage. The line is chosen without thought of footing; bog, windfall, under-brush, are taken as they come; the ax touches nothing that can possibly be wormed through or straddled over; blazes are rare enough to compel a watchful eye.

It would have been quite too long a day, for one member of the party at least, had the carry begun at the door of our cabane, but an old road offered dubious aid for the first five miles. Once the well-travelled highway from the St. Lawrence to Lake St. John; now there be few, and they of great faith, who hold it passable. Nature, striving with unwearied persistence to undo the work of men's hands, is within a very little of her final victory. The horse wades a green channel narrowed and shallowed with young trees and bushes at bottom and sides; the wheels, sinking al- 


\section{IN A FISHING COUNTRY}

ternately to the hubs, follow invisible ruts; holes and high places alike are garnished with boulders; a little of this "carriage exercise', and one is fain to walk for a rest. In or out the planche, the living cargo manages well enough, but safer provision must be made for a more precious freight-the canoe. A buckboard is trimée to carry it on firm supports, bottom up, lashed with extremest care, projecting almost to the head of a horse chosen for sobriety of demeanour. Your flighty inexperienced beast, rushing at a difficulty, would wreck everything; an old horse, like an old dog, is to be trusted for the hard road. The sagacious Cog has learned in a lifetime of such pilgrimages to test every foothold before throwing weight upon it, to extricate himself with slow deliberation from the worse chaos of boulders and rotten wood-un cheral $\mathrm{com}$ mode, as the world concedes. And Pommereau, the Coq's incomparable master, is at hand to con him through with all that store of wise and timely words for which the restless white ears ever keep listening.

Even the Coq is halted by a deep gully, with the decayed timbers of the bridge that spanned it strewing the rocky bed. A 


\section{JACK-O'-LANTERN}

glance shows the place impassable for wheels; ten seconds suffice Bébé and the younger Thomas to measure the chasm and set to work. With what swift ease each throws his ax-head deep into a tree that presently falls just as he would have it, is lopped and laid! The smooth kerfs tell how every whistling stroke bites to a hair. Neither word nor motion is wasted from first to last. Again two spruces crash, are cut to length, and the ax-men stand face to face at the ends of a log. The steel buries itsclf precisely in the centre; the other ax sinks, in line and close beside; the first hisses into the widening split; at the fourth blow the log rends in equal halves-two broad floor-beams. I doubt that the building of this bridge, and of another like it further on, lost us twenty minutes, where, aided by less accustomed hands, the delay would have run to hours. Thoughtful ever for their beasts, the men threw blankets on the waiting horses-all but the Coq. Someone draws Pommereau's attention to his omission. Scorn is in his gesture:'Courvir cet animal-là? - le cheral éternel!'

After being walled in by forest for mile after mile, the eye leaps across a more ex- 


\section{IN A FISHING COUNTRY}

tended prospect with delight; the valley of the Cruche, bare of trees to the craggy mountain tops on either hand, opens suddenly below us and we feel the exhilaration of a release from confinement. Growth is slow at an altitude which gives this plateau the climate, fauna and flora of the Labrador, but every inch where a seed can root itself has some lowly tenant. Only is nature balked when the vegetable mould has been devoured by fires. These must have happened from the beginningthough lightning does not work a hundredth part the damage wrought by the stupidities of man-for twice in our short day the bolt was seen to strike and kindle. When the very soil itself is gone, nothing remains but glacial boulders, sand and gravel. Then must begin anew the long processes, through a chain of the humbler forms of life, which after many centuriesfire sparing the patient attempt-will restore that wherein trees may flourish. Even the first clothing of the barren surface with moss is so deliberate an affair that progress can hardly be noted in the lifetime of a man.

The Rivière de la Cruche, now a large brook, and in spate not unworthy the name 158 


\section{JACK-O'LANTERN}

of river, had swung its bridge to a firm lodgment on the further bank. Abandoning the idea of replacing the heavy structure we unharnessed the horses, persuaded them to take the plunge under leadership of the Coq, and crossed the planches by hand. It was the last obstacle; thanks to watchful care that left no tricks in the game to chance, the canoe was unloaded at Lac Cran Rouge with no worse than an insignificant scrape or two upon her canvas.

The tenth in a series of useful interdicts (conveniently interpreted with a little wise discrimination) forbids the coveting of other men's goods. In my construing it is not concerned with the incorporeal-with that gift of my neighbour's, for example, whereby he is able to imprison upon a scrap of paper, with a few cubes of moistened colour, what things go to make every fresh Laurentian lake unlike all others, its very self:- the marks and traits of individuality in curve of shore-line, gleaming beaches, gray cliffs that plunge to deep water and dark, reed-fringed bays shadowed by the crowding ranks of the spruces, little capes where birches stonp nver the lichened boulders, the frowns and smiles upon an 


\section{IN A FISHING COUNTRY}

ever-changing face as the sun swings through its round, the set of the enclosing hills. Uncovetous of oxen and asses, menservants and maidservants, I confess to black envy of him who thus can bid the fleeting instant stay.

How fair a task, how worthy the years it would joyously fill, the painting of a little river's life! - a fecble birth in mountain mosses, shy infancy nursed by quict forests, youth dreaming and loitering through broad lakes, the wild adventures of adolescence, the calmer usefulness of full-grown strength, and, at the last, euthanasia in St. Lawrence tides across the wide brown sands. Painting always, everywhere, the transitory mood that bestows the living soul; for I affirm with the dogmatism of an ignorance not desiring instruction that any picturing of land or water which does not carry plain signature of season, weather and time of day is but a death-mask.

All too brief the paddic across Lac Cran Rouge to the blaze which marks the beginning of the new trail, and we are adjusting packs for the long pull down to the Murray and up to the headwaters of the Riviere Porc Epic, - a fall and a climb of five or six hundred feet. Fvery fifteen minutes 


\section{JACK-O'LANTERN}

the canoe shifts from shoulder to shoulder, but our small burdens were hardly set down in three and a half hours of dead slogging. Climbing the arid slopes that hot June day, ridge beyond ridge, the old man, with his pitiful twenty-five or thirty pounds, felt more and more like Christian on the hill Difficulty. As I recall the ancient woodcut, you could see no more than a pair of bowed and staggering legs beneath the immense bundle of his sins; the pilgrim was headed away from you and thus were you baffled in the vital enquiry whether his tump-line took the weight upon chest or forehead!

Only on the return could we spare a look at the twin mountain chains trending northward in vast curves, with precipices falling sheer to the lower slopes of the broad spruce-clad valley, scored here or there with rock slides but untouched by the ax. Not many miles below our crossing the hills draw in, and the river plunges more than a thousand feet in cascades and furious rapids through so wild a gorge that none can follow it. After this turbulence the stream finds rest in a canyon where stately trees, and brooks leaping from the rim, give something whereby to measure 161 


\section{IN A FISHING COUNTRY}

the stupendous walls; unlike the Saguenay's fiord, before whose equal cliffs the eye is helpless.

The Lake of the Long Blue Ones-otherwise Lac à Moreau, named after the Montagnais-would have been welcome in any guise, but we fell on a lovely sheet of glassgreen water lapping clean sandy shores from which the unbroken woods stand back to give wide breathing-space. A bold peak guards the upper end; the rounded summit, planed smooth afore-time beneath a mile of flowing ice, is now caressed by slow-moving clouds. Innumerable shades of new leafage below merge into the gray of moss and weathered granite aloft. The Indian chose passing well; it is many a year since he swung an ax, the traces are blurred, but a few mouldering stumps and healed-over blazes yet mark the spot which was his home.

A site, commanding lake and mountain, found for the tent, forthwith three imperious needs arose, nor was either member of the party troubled with doubts as to the order of their precedence-drink, swim, food. Five yards from the tent the mosses distilled a tiny freshet which might have served by itself to slake thirst, but the day's 


\section{JACK-O'-LANTERN}

work was all behind us, soul and body cried out in bitter need. Surely the Recorder, with the instincts of a gentleman, turned his face away at the pouring, was inattentive to the long gurgle, or tempered his entry in the column devoted to remarks with a word of kindly mitigation!

The weather seemed propitious enough, except that the wind, difficult to assign to an exact quarter in a broken country, appeared to be in the south-east. The vice of this unloved air is in quality rather than direction. There are east winds without guile; on the other hand a shift from east may bring no change of character. The true nord-est, precursor of all that is ill in the way of weather on the St. Lawrence, fishtails up the valleys in the confining sides of the immense funnel, and arrives in the mountains from the south-east or even the south. A stranger is bewildered to find it called a nord-est in defiance of the compass, until he learns that the name describes a type. On the days in question there was, in truth, a nor'easterly gale below, and I am bound to make it part of the record that this maleficent influence was abroad.

The purpose was to spend a long evening on the remoter lake. This left but half an 


\section{IN A FISHING COUNTRY}

hour for Lac à Moreau; time enough, however, to prove that the lake was filled with trout to its capacity for sustaining them. They had multiplied at the expense of dimension; had become une race dégénérée. Large fish there might be, almost certainly were, though not in the humour for disputing the surface supply of food with smaller nimbler competitors. One of a full pound was the best we took, --a strong though slender fish, bright as a herring, justifying the ancient account in all but size."

Tradition placed our two lakes a few hundred yards apart, for time deals kirdly with distance and difficulty; it took a long half hour to make the portage, even with the aid of the canoe in crossing a couple of ponds. These had the dead unwholesome look of water unrefreshed by a living stream; the moraines containing them might easily have been mistaken for old

*Jt has long becn matter of common obscrvation that the colour of a trout depends upon his environment and changes with it. A new and strange fact not long since has come to light. Where the trout in subterranean waters are blind, or where trout lose their sight, no such change takes place. The process then is not antomatic and mconscinus (as one might supmose it to be), but the trout has a chameleon power of harmonizing himsclf with his surroundings as the sees them. 


\section{JACK-O'LANTERN}

mill-dams. Beyond the further was a quarter-mile of climbing, squirming, balancing, leaping from one unsteady foothold to another, in burned windfall. Thomas, with the canoe on his head, made nothing of this obstacle race, but each of our four traverses aroused in us a feeling of irritation at these acres of charred spillikins. With relief we laid legs to a stiff pass and from the top plunged steeply down, following a moose trail worn deep in the black muck, to the marshes which feed the waters we were seeking.

At this moment of the year the quaggy flats were a garden of the rarest beauty. The Labrador tea was in fullest bloom. Amid the creamy masses flowered the swamp laurel,-fleur des savanes-the dainty coral blossoms, every one solitary on its slender stem, arranging themselves in a thousand whimsical groupings. On this gloomy bit of bogland the wayward pink bells swaying in the wind, composing themselves afresh against the rich and solid ivory background, conferred a brief day of loveliness.

We are soon at the edge of a little tarn to which the high and densely timbered hillsides grudge room. Black and myster- 


\section{IN A FISHING COUNTRY}

ious, shadowed and profound, it seemed fit harbourage for a bunyip strayed far from its native pool. The stream where the elder Thomas saw his vision flowed in at our feet, but no back fins were above the surface, nor was there movement anywhere till the ripple of the first canoe launched from that shore broke the reflections.

Wind apart, a better evening could not have been chosen for a test; warm it was, and overcast, with little flaws now and then ruffling the surface. A few may-flies were upon the water, but only one fish was noticed feeding. Where the brook leaves the lake three or four small trout made curiously timid feints at the fly. After an hour or more of casting over every nook and corner, a two-pounder banged up in the middle of the lake with upsetting suddenness - a powerful fish, well shaped and nourished, and led most reluctantly to the net. A mild presumption as to cannibalism is raised by the fact that he took a Parmacheene Belle. Another long bout of essaying lures and changing flies, and a second trout of at least equal size rose at the same spot, but did not touch the fly. For above three hours, till the sky would barely light us home, we used all our poor arts on the 


\section{JACK-O'LANTERN}

Lac du Gros Ruisseau - the Lake of the Fat Red Ones. Three hours more of diligent labour the following afternoon, in weather that could not be quarrelled with except for the same untowardly wind, was only rewarded with one fish of a pound and a quarter who dashed for the fly when hope was almost gone. Heavy rain from five o'clock to six did not stir the trout to activity. On neither day was there token of the evening rise that is usually so marked at this season of the year.

Indulging in meditation and conjecture (many others must have done so upon a like experience), what conclusions is it fair to draw as to the lake and its inhabitants? One may set out with the safe assumption that an undisturbed water carries such a weight of fish as the food will support, and food there was in plenty. The units here must be large and relatively few; had they been small and numerous they could not have failed to disclose themselves, even under conditions not wholly favourable. The nervousness and shyness of the little ones that rose in the shallows point rather to harassed and precarious lives than to an atmospheric cause. They avoided the deeper parts, probably with good reason. 


\section{IN A FISHING COUN'TRY}

Not many, one may guess, survive to maturity. Trout of two pounds argue for larger fish-are in a class where possibilities run high-but the disposition of such towards the fly is in inverse ratio to size. These rarely feed upon the surface, are more sensitive to adverse influences and less easily tempted than the smaller fry. Very capricious and difficult they may appear to us who have so poor a clue to their motives. Six hours of attentive fishing, albeit in the time of the June rise, proves, perhaps, that the trout of the Lac du Gros Ruisseau are not ready surface-feeders; it by no means disposes of the tradition, nor excludes the chance that on some exceptional unpredictable day they will accept the fly with eagerness.

A luckier fisherman here may fall upon immense trout, finding them so unreluctant that he will be amazed at our failure. I recall attempts upon another lake of this type, in good weather, fishing late and early (to the point of setting night-lines) where not a warrantable fish was seen; and yet it was so that on a certain day, to mere human eyes like other days, the water boiled with huge trout that rose at anything, hopelessly smashing the angler's tackle. 168 


\section{JACK-O'-LANTERN}

A word here, perhaps of doubtful canonicity, to the dry-fly man. I was telling the companion of many voyages how impossible we had found it to interest the very large trout of yet another lake. The Indian smoked and meditated awhile.-Did you try butterflies?' We had not; and he assured me that a floating butterfly was the fellest temptation with which you could assail a fish.

When the hour shall strike for the right man, perchance the very pair that lay by the bank so many years ago may still be awaiting the fly to be dropped by his more fortunate hand. It is not likely that a few decades will make his way easier-unless he follow the smooth paths of the air-and he will have justly earned what success attends him. In the meantime, Lac du Gros Ruisseau takes its place provisionally in a certain list of half a dozen lakes where trout, great beyond the common, hitherto have beaten the fisherman. With the friendly warning that every one of them is far away and hard to tackle, the roll is at the service of any true man.

Unpermitted to wring the secret from this dark water, we turned our backs upon its inscrutable surface, the sedgy margins, 


\section{IN A FISHING COLNTRY}

the frowning steeps; wondering much whose eye might next fall upon them, and what tale he would have to tell. Should it be better worth the hearing than ours, he will, if wise in the ways of fish, render to Chance her proper dues.

A great congregation of mosquitos, eager to risk their lives for the single drop of blood nature bade them demand of us, was gathered in the tent, but we disconcerted them and won a blinding choking kind of peace with a smoke-screen hatched in a lard tin. The last care before turning in was to replenish the smoulder, and gather a store of punky wood against the evil hour. Earliest dawn brought the enemy back, incredibly reinforced. The smudge was dead; the lard tin vanished; almost one suspected that the mosquitos, in a fine collective effort, had made away with the engine of their discomfiture. A long groping disclosed that the young man, head tucked under blanket, was grappling the fire-pot to his bosom. He yiclded it sleepily; a cloud of full-flavoured incense gradually reduced the clamour of wings to silence. But sleep was fitful and shallow, as it is likely to be when excessive fatigue has begotten nerve-irritating toxins. The 


\section{JACK-O'-LANTERN}

lesson was re-learned that when really tired one should not eat. Always true the saying, but then especially,--'who steals an auld man's supper does him nae wrang'.

The Lake of the Long Blue Ones had to be faithfully dealt with, but a conscientious whipping of bays and narrows brought no change of opinion. In the shallow channel where the river Porc Epic enters, were shoals of smallish trout. One had not realized how transparent are these light-complexioned fish in strong sunshine. Their bodies were lucent with rosy colour; every fin, its framework skiagraphed, was like some delicate and brilliant flower moving in a current of air. Working up the sandy encharge, where the whole population of the lake must assemble at the spawning-time (where, I doubt not, the Indian children had fished so successfully) a feathered grenade exploded within reach of my paddle. If the loon guarding nest and eggs to the last instant suffered as great a fright as she gave, her alarm was extreme, for she nearly startled me out of the canoe.

There would be difficulty in setting limit to the number of small trout one might take here in a day's fishing, but we 


\section{IN A FISHING COUNTRY}

saw nothing larger than the pounder of the first afternoon. Whatever the average weight of the fish may once have been, this lake, like innumerable others, now carries fivefold the number (at a fifth of the size) that an angler would desire. Ridded of the surplus in some legitimate manner, the fishing would soon be vastly improved. To destroy what cannot be used being out of the question, is the situation without remedy? Why should it not be commercially possible to market this ungathered crop which renews itself perpetually? The potting of charr is an industry in England; fresh-caught trout, cooked with bacon and tinned, would find a ready sale. Thousands of lakes are under the disadvantage (from the angler's point of view) of being overstocked with a delicacy for which there is an endless demand. It only remains to establish contact with the consumer. Instead of there being a discrepancy between commerce and sport, they should play into each other's hands. A regular supply of fish suitable to pack could only be obtained by netting, which would then have to be made lawful in waters under license to a cannery, upon a carefully thought out plan, with proper 172 


\section{JACK-O'-LANTERN}

safeguards and restrictions. Those who are leaseholders of neighbouring lakes and streams for fly-fishing might permit netting under their guardians' inspection and control, with limitations as to time, size and quantity. Practical objections, perhaps not easy to deal with, are quite apparent, but, were they overcome, anglers would enormously better the quality of their fishing, while aiding a most useful enterprise.

Slipping down the long descent to the river in easy fashion, we gave an hour to the likely-looking pool at the crossing. A stiffish rapid dances into and across it, with eddies on both sides; here is no great depth, there the slow-circling water is dark and flecked with foam. No foot of it all, where fins can hold against the current, is untenanted. The members of this needy community are driven to snatch at anything and everything on the chance that it will relieve a chronic hunger. This was the very spot to let loose an ardent lad, and give him once and for all his fill of slaughter. A certain rise at every cast, often several trout contending for the same fly, and a fair number over the half pound to bend his rod and teach him the music 


\section{IN A FISHING COUNTRY}

of the reel. He and a companion setting themselves to it, and their tackle not succumbing under excitement, would load two men in the course of an afternoon with some forty dozen trout-resting forever content with the feat, one may hope. It is quite a little knack by itself to avoid hooking the small ones; we had good occasion to practise it. For some reason, hidden from our eyes and intelligences, the heavy trout do not harbour in this superb pool. It was intimated to us as plainly by the great plenty of the lesser fish and their reckless demeanour, as by our failure to see a broad back or attract a rise.

Slopes that are not very perceptible under the heel are easily detected when you face about, and a thoroughly wetting rain never made a pack seem lighter or a march shorter; wet from without in and from within out, tired and hungry, we felt it. a voluptuous release-so relative a thing is happiness---to throw off our packs at Lac Cran Rouge and limber up necks that were stiffened in the posture of carrying.

One last item stood on the program,-a digression of a few hundred yards through sodden caribou-barrens to the shallow sandy-margined Petit Lac des 


\section{JACK-O'-LANTERN}

Grosses. Black gusts of wind and rain fell upon us from the heights as we made the short paddle from the marshy to the wooded end. Imputing our own feelings to the trout, it seemed unlikely that they would be concerning themselves about flies, but, in fishing, your ounce of experiment far outweighs your pound of reasoning. Before trying the luck, however, the voice of prudence was hearkened to, and we dried out. It matters little how chilly a person in health becomes by slow degrces, but when fatigue and wet have cut down the factor of safety, cooling off is perilously rapid. Uncontrollable chattering of the teeth is the woodsman's recognized signal of danger-disregarded at one's peril.

Comforted by food and a great fire, we pushed out to the deepening water where the sands fall away, and at once a fish rose that stripped the reel of line with surprising swiftness. Before he was netted there was plenty of time to guess at his weight, and the estimates were wildly flattering. Seldom, perhaps never, had any of us encountered such splendid gallantry. With a very light rod there is no saying how long he might have resisted, for he had shown no sign of surrender when a fortunate 


\section{IN A FISHING COUNTRY}

motion of the net secured him. The scale's testimony that our dozen averaged little over the pound did not at all agree with the impression given in the taking. These samurai among trout will remain a standard not likely to be displaced, but the mystery of their excellence is utterly hid from us. Surrounded, as they must be, by all that makes for perfect development, nature lays some mysterious check on multiplication.

Unlike Lac à Moreau, where natural increase is unrestricted, a moderate and stable head of trout is here maintained in the very pink of condition. Supplied with food convenient in kind and quantity, they find a good living, but are not relieved from working for it. The lake only fishes well in dark weather, or late in the evening, which means that the trout can afford to bide their time.

Unlike Lac du Gros Ruisseau, the depths do not yield so ample a provision that the fish lose interest in the table spread for them upon the surface. An extremely rare conjunction holds the balance truea balance to delight the fisherman whose ambitions are qualitative rather than quantitative. Man has little hand in this 


\section{JACK-O'-LANTERN}

particular adjustment, for the lake scarcely knows the fly, but rare conditions do arise where the same happy end may be attained by artificial means.

The horses, each one under his dusky nimbus of flies, were waiting impatiently. The tying on of our traps in ship-shape fashion seemed an unkind further delay, as the careful lashings would have to be all undone at the awkward river-crossing a mile away. The men overruled a mild suggestion that we were losing time. Well, it was their job, why interfere? Moreover, is it not always a mistake to hurry anyone? The quick man needs no admonishment-may be thrown out of his stride by it; the slow one is always fussed and made slower; the residual advantage can only be such personal satisfaction as you derive from speech.

In this case words would have been doubly a mistake, for, arrived at the Rivière de la Cruche, a sound bridge spanned it! We were the victims of a finished and exquisite practical joke which all hands had been in a conspiracy to keep dark. What conceivably more amusing than to borrow an hour from the morning, and spend it waist-deep in cold water 


\section{IN A FISHING COUNTRY}

swinging the heavy timbers back to place, raising and staying them! Well worthy the labour and the wetting to see the dumb amazement of les Messieurs when the jest smote upon their eyes! So thought the incorrigible boy of seventy-odd who constructed the little farce out of his young heart's abounding humour and goodwillsmoother of rough places on the hard road of life-builder of ways for othersPommereau, pontifex. 
$\mathrm{T}$ 



\section{$\mathrm{T}$}

But a single favour does he stiffly refuse a friend: that he should lay aside ax and paddle for the laborious intractable pen, and tell us children of the pavements about his aciventurous life in northern Quebec. He holds it would be a task excessive, uncalled for, immodest, to write of his many years with the Indians, the ups and downs of fortune that visited them as they ranged an unmapped wilderness in company-hunting, trapping, fishing. Speech itself he distils only under pressure, in an apologetic trickle, not with the fine free gush of the tap that invites your turning, or is adjusted to an automatic flow.

Around the camp-fire, when the several gifts of the company are thrown into hotchpot, he does not withhold a story or a song, but prefaces it with a disarming word very recommendable to the coy performer (possibly no nightingale, either) upon whom the entreaties of the drawingroom converge:-Eh bien! Depuis que rous le roulez. On connait parfaitment que chaque animal a son cri!

Stimulated thus, or when some accident 181 


\section{IN A FISHING COUNTRY}

of voyaging has stirred a memory, at odd times and in odd places, the originals of these dim copies were revealed to us; some trivial mishap on the trail perhaps bringing to his mind a day when life and death hung upon the noosing of a hare, a shift in the wind, the turn of a paddle.

Here, then, was such a place and time. $\mathrm{T}$ was never for risking open water where the gain was small, and his caution had a surprising way of justifying itself against the canoe that insisted upon a straight line being the shortest one between two points. At the moment, however, sea and wind left no choice in the matter of crossing a lake, and we were holding close inshore. His long and heavy paddle used as a pole, $\mathrm{T}$ - _. was shoving mightily round the shallow edge, taking an eager part in the talk of our prospects upon some new waters. A sentence shouted at our backs against the stiff breeze broke off short, the canoe ceased to smash into the waves, a burst of laughter that seemed in no wise pertinent swung us about to see the end of the paddle sticking up from the water and just comfortably out of reachthe blade fast between two rocks at the bottom. The wind, setting a bit towards land, 


\section{$\mathrm{T}$}

soon drove us in; a pole was cut, the paddle retrieved, and the little contretemps had this for its sequel:

'I was paddling up a great river of the North Shore with six Indians, carrying in supplies for the winter hunt. Each of us had his own canoe and a full load. We came to the foot of a fall where the river drops twenty-two feet sheer, and has hollowed out the rock behind into an immense cavern. The water inside there boils and rages; everything that comes down is drawn in and churned to bits. It is but a short portage up the rocks at the side and you put the canoes in only a little way above the fall, but you must get off quickly and paddle hard, for the water is very swift. I was the last to launch, and I put the paddle hastily against the stones and pushed with all my strength. My hands came away empty! A crevice held the blade and the canoe was driving out to midstream. The other paddle was in the bow: think of the folly! I crawled to it on my belly over the pile of baggage. The draw of the fall had me then-stern foremost. There was no time to shift, or turn the canoe. It was too late...' 


\section{IN A FISHING COUNTRY}

'But you are alive today-not a ghost! How... ??

'I paddled for the centre of the fall as never in my life. Where the water curves the canoe shot straight out. It landed below on an even keel and broke in two, but it carried me just so far that I was not sucked back and under. The river threw me this way and that, and when an eddy swung me near the shore I still had force to clutch the branch of a tree... they found me there.'

'Yes, others have been caught; the water is so smooth that it tricks you. But no one ever had my good fortune.'

... Death laying against the field...the odds taken in this instant desperate resolve ... heart and nerve fail him not, nor. cracking sinew... his paddle tears the dark water into foam...the bark cleaves unswervingly for the glassy curve-ever forming-vanishing...flies the stark face above it down to the thunder and the mist. . .

On that trip, or another, his party was wind-bound on its way to the coast-midway on the shore of a lake near a hundred miles long which narrowed, for a little distance, to ten miles where they came out 184 


\section{$\mathrm{T}$}

of the woods. Day after day, night after night, the north wind blew down the lake; fetching a sea from fifty miles away which their small canoes were not able to master. Provisions were very low. The daily ration was a tea-spoonful of flour drunk in a pannikin of water. Game there was none; strength waned; starvation neared. On the further side lay their food-câche. Though the wind had not abated, someone must try a forlorn venture. A canoe was carried through the woods to the windward end of the narrows to make up some of the leeway that would be lost in the tenmile crossing. At dawn it was launched, and all the long day $\mathrm{T}$ fought the wind and the sea. Only now and then could they let the canoe fall off and steal a dozen yards on their course, for the breaking waves must be met squarely, or the canoe be swamped. As night came they found themselves sweeping helplessly by the point they were striving to gain,past, and only a few hundred yards from it. There was nothing left in them for a last effort against the heavier and shifted wind. In a black despair must they turn, or be carried out to the lake's wide lower expanse where a canoe could not live. Some- 


\section{IN A FISHING COUNTRY}

how they recrossed through the hours of the night, falling exhausted where they reached the land-lying where they fell. And still the merciless north wind held,-for one week, two weeks, three weeks. At last, one night, the gale eased, and a band of skeletons, paddling feebly and unsurely as little children, made the slow traverse.

Quinsy, at the best, is a miserable enough ailment. When next it afflicts you try to discover solace in a contrast. From the snugness of a warm bed and a tempered room transport yourself to a narrow couch of poles, strewn with branches, in a six-by-eight cabane de chasseur-almost buried under the snow. No doctor will get on your nerves with his professional cheerfulness and nicely calculated sympathy; no nurse will annoy you with her fussy ministrations. In place of carefully prepared slops at carefully timed intervals you will make yourself broth of melted snow with a bit of flour, or the frozen leg of a hare. The sheet-iron stove as big as a hat-box must be kept red-hot or you perish; beneath the drifts outside there are dead trees a plenty. The chemist's shop round the corner is represented in this case by a pitiful half-inch of 'Pain- 


\section{$\mathrm{T}$}

killer'-in a bottle ten miles away. After three parched days of not being able to swallow, a desperate faith in the virtue of this remède will drive you forth to stagger after it on snow-shoes across the mountains, -with swimming head and fever-weakened knees... Such contemplations, even if they do not relieve the knife-thrusts at your throat, may be fruitful in mitigating someone's task as nurse!

One weary march is pretty much like another, and la misere is all of a piece; I shall not attempt to journey with $\mathrm{T}$ to unknown head-waters, nor pursue the long solitary rounds of his trapping. When the days of reminiscence are upon him there is much that he may tell, but upon one theme of peculiar interest I doubt that he will allow himself to touch: the arts and practice of Indian magic. Of this he speaks reluctantly, as a thing beyond comprehension or explanation; showing the puzzlement of his mind in the phrase:on parle des choses incroyables. The years he passed with the Montagnais gave him many opportunities to watch their jonglerie; intimacy with their language and customs, the close comradeship which 


\section{IN A FISHING COUNTRY}

unites brothers of the chase, adds a peculiar value to his testimony.

The subject is best introduced with quotation of the classic account by Alexander Henry, to which Parkman refers. This relates to a high ceremonial occasion, but the ritual is the same for lesser invocations; as, likening great things to small, the imposing offices in a cathedral resemble those humbler ones 'where two or three are gathered together.'

Henry was a profoundly religious man, a cool and accurate observer, wholly sceptical as to Indian sorcery. After detailing with much minuteness the preparations, the erection of the medicine-lodge, the purification of the ministrant and his entry, the description runs:-

' $H$ is head was scarcely within side, when the edifice, massy as it has been described, began to shake; and the skins [covering it] were no sooner let fall, than the sound of numerous voices were heard beneath them; some yelling; some barking as dogs; some howling like wolves; and in this horrible concert were mingled screams and sobs, as of despair, anguish and the sharpest pain. Articulate speech was also uttered, as if 


\section{$\mathrm{T}$}

from human lips; but in a tongue unknown to any of the audience.'

'After some time, these confused and frightful noises were succeeded by a perfect silence; and now a voice, not heard before, seemed to manifest the arrival of a new character in the tent. This was a low and feeble voice, resembling the cry of a young puppy. The sound was no sooner distinguished, than all the Indians clapped their hands for joy, exclaiming, that this was the Chief Spirit, the TURTLE, the spirit that never lied! Other voices, which they had discriminated from time to time, they had previously hissed, as recognizing them to belong to evil and lying spirits, which deceive mankind.'

'Questions having been put by the priest, the tent instantly shook; and for some seconds after, it continued to rock so violently, that I expected to see it levelled with the ground.'

'A quarter of an hour elapsed in silence, and I waited impatiently to see what was to be the next incident, in this scene of imposture. It consisted in the return of the spirit, whose voice was again heard, and who delivered a continued speech. The language of the GREAT TURTLE, like 


\section{IN A FISHING COUNTRY}

that which we had heard before, was wholly unintelligible to every ear, that of the priest excepted; and it was, therefore, not till the latter gave us an interpretation, which did not commence before the spirit had finished, that we learned the purport of this extraordinary communication.'

The 'extraordinary communication' delivered at Sault Ste. Marie in June 1764 had to do with the warlike preparations of the English which were then proceeding at Fort Niagara and Montreal, and the chances of a friendly reception at the hands of Sir William Johnson in case the tribe should pursue its journey, ask for a parley with him and offer to abandon French for English allegiance. As history knows, the oracle favoured this policy, was immediately obeyed, and everything befell in accordance with its predictions.

- The question of public interest being resolved, individuals were now permitted to seize the opportunity of enquiring into the condition of their absent friends, and the fate of such as were sick. I observed that the answers, given to these questions, allowed of much latitude of interpretation.'

'Amid this general inquisitiveness, I yielded to the solicitations of my own 190 


\section{$\mathrm{T}$}

anxicty for the future; and having first, like the rest, made my offering of tobacco, I enquired, whether or not I should ever revisit my native country? [He was then a prisoner, still in some peril of death, after many years of voyaging in the WVest]. The question being put by the priest, the tent shook as usual; after which I received this answer: "That I should take courage, and fear no danger, for that nothing would happen to hurt me; and that I should, in the end reach my friends and country in safety." These assurances wrought so strongly on my gratitude, that I presented an additional and extra offering of tobacco.'

'I was on the watch through the scene I have described, to detect the particular contrivance by which the fraud was carried on; but, such was the skill displayed in the performance, or such my deficiency of penetration, that I made no discovery, but came away as I went, with no more than those general surmises which will naturally be entertained by any reader.'

David Thompson, incomparably the greatest contributor to the precise geographic knowledge of North America, (and the tenant of an unmarked grave in Montreal) likewise a pious and trust- 


\section{IN A FISHING COUNTRY}

worthy man, wrote somewhat later revealing himself another perplexed sceptic. He saw the medicine-man bound with sinewline-thumb to forefinger, every finger to its neighbour, wrist to wrist, arm to arm above the elbows, toes in the manner of the fingers, knees, ankles, body and arms together, a strong line under the knees and over the neck-half a dozen turns-drawn tight and tied. Not yet enough! The victim was folded up in a large skin, and more yards of rawhide were lavished in making a bale of him. Trussed and parcelled in this fashion he was carried to the 'conjuring-box' and left there. After fifteen or twenty minutes the whole of the cords were thrown out; there was sound of rattle and song; predictions were uttered. The lodge was built on a piece of clear ground. Thompson could discover no sign of collusion. He pronounced the whole thing 'a neat piece of juggling.'

In his party were 'five Scotchmen' who proposed themselves to do the tying. The Indians 'readily agreed' (Pity the poor savage in the hands of these dour and doubting Scots-'Haud on, Sandy.'-'A wee tighter, Jock.'-'Gie him yin roond the thrapple'--'Anither here'-'Pull, ye dee192 


\section{$\mathrm{T}$}

vil!'-'He'll no slip awa noo'-and where, in mercy, did they find room for 'anither' knot!)

'To their utter astonishment' the medicine-man freed himself as readily as before.

'My men were at a loss what to think or say.'

The Church forbids sorcery, and has from the beginning; but there is still resort to it in the far interior, where some urgent need arises. Though the jongleur stands condemned as a Valet du Diable and a Ministre de l'Enfer, a few are still living who know and practise the arts-making peace later for their sin. Condemnation attaches to the means rather than to the end: to the commerce with the devil and not to those innocent, even praiseworthy, objects for which he is invoked.

Nigh upon 300 years ago Père Le Jeune proposed to himself the question "whether the Indian Sorcerers have communication with the Devil'. His view at the outset was that 'all the things these Sorcerers did were only Deceptions they contrived'-by means of sleight-of-hand and ventriloquism. He describes the erection of the 'Tabernacle', the inexplicable way in which the stout building was agitated, the strange 193 


\section{IN A FISHING COUNTRY}

diableries that issued from it. 'Some day' says he 'I shall know if there is some deviltry in what they do, at present I can only assert that some say yes and some say no.' Later, he returns his answer:-'If what I have heard be true one may not doubt that Demons sometimes traffic with them. Till now I was for believing that the Devil played with them, filling their minds with delusion and their wills with malice; so was I persuaded that he did not reveal himself in person and that all these Sorcerers did were but jugglings contrived for profit. But now I begin to doubt, even to lean to the other side ...'

"Wintering with the Indians I saw this deviltry... was astonished... all these reasons make it seem likely that the Devil is sometimes in actual touch with these poor Barbarians

Thus the incredulous Le Jeune was slowly converted, and others of the Fathers of his day came unwillingly to the same opinion. Father Pijart found himself confronted with strange and incredible things which brought him to a belief in demoniac influences. Father Bréboeuf writes Le Jeune:- 


\section{$\mathrm{T}$}

Ges gens a mon advis sont vrays Sorciers, qui ont accez au Diable... Le Diable leur. revele quelques secrets mais avec tant d'obscuritez qu'on n'a garde de les arguer de mensonge... G'est ainsi que le Diable amuse ce pauvre peuple.

And again:-Il y a donc quelque apparence que le Diable leur tient la main par fois, et souvre à eux pour quelque profit temporel, et pour leur damnation éternel.

An age of credulity, it will be said: on the other hand recollect how gladly these educated gentlemen would have exposed the medicine-men's pretensions, how reluctant they must have been to admit the presence of dark inexplicable powers, contending with some success against the gospel they were preaching with such tireless zeal, at peril of their lives.

The interventions of the medicine-man which $\mathrm{T}$ - has observed were commonly with the object of enquiring whither the band should direct itself for the winter hunt-where game and fish and fur might be secured most easily, with the least risk of mishap. Questioned as to whether the predictions were fulfilled, T- replied that frequently it had been so; adding, properly enough, that this might be due to 


\section{IN A FISHING COUNTRY}

astute guessing or to mere coincidence.

A feat more difficult to explain is the recovery of a lost article for the owner. Elsewhere I have related how the sceptical Bastien's knife was restored to him from an impossible distance in an impossible space of time. This intelligent and very observing man had no guess to offer as to how the thing was done.

In every case, whether aid is sought or advice, the want must be a real one. Idle or curious appeals to the oracle are not sanctioned. The need of counsel must be urgent, the property to be recovered indispensable. The replacing, for example, of a broken ax-head may be considered as worthy the efforts of the spirits and their minister; at the end of the usual ceremonies, $T$ - has seen a new ax-head disclosed upon the raising of a vessel from the sand which before lay bare. There was no pretence to create this out of the void; the assertion was that the actual blade had been fetched by the spirits from the trader's store-perhaps a couple of hundred miles away. Words comfort even where they do not enlighten, and we should describe these processes as dematerialization, conveyance from place to place in unsubstantial form and subsequent rematerialization. 
Whether it be question of ax-head, powder, ball or tobacco the seeker of favours must solemnly engage himself to make good to the trader at the first opportunity. The stipulation is invariable. Neither the spirits nor he who summons them will be party to a dishonesty. This element of the transaction does not appear upon the face of the earlier accounts, but one greatly doubts that it is in the nature of a Christian veneer over Pagan custom. Probably it was always there, though unnoted.

Upon both the new heads-the existence of actual emergency before the spiritual machinery may be set in motion, the obligation to render payment- $\mathrm{T}-\mathrm{C}$ 's evidence is clear. In the other respects he bears out former narratives so closely that it would be but repetition to set down the details afresh; nor has he the least further light to cast upon the strange occurrences which have passed before his eyes. With conscience and mind disposed against belief, after following the whole course of the proceedings with sharp-eyed attention, he was left as wholly in the dark as those others-not even names to him--who have been called here to witness. 


\section{IN A FISHING COUNTRY}

What judgment should be passed upon the facts?

Le Jeune, Pijart, Bréboeuf, Henry, Thompson, we have heard. As for This first word is his last:-On parle des choses incroyables. 
$\mathrm{N}$ 



\section{$\mathrm{N}$}

Two things there are, sad beyond all other: a great mind's slow undoing; the untimely stroke that makes sudden wreck of a noble frame. How little in the bearing of this figure shambling to a seat by the fire that recalls the man upon whom, alike in movement and repose, the gaze was wont to rest with such content! Yet, his undimmed eye roves the horizons of the $R \circ y$ des Fleures, discerning afar the faint signs of coming change, and the unquenched spirit loves to pursue old forest trails, to follow once again the tossing white waterways.

In admiration of a companion among a thousand, in gratitude for much taught, a little learned, I gather these few memories.

Indian of the three-quarter blood, his parental grandfather French, he unites the high qualities of the race. Taciturn but never morose, meeting good fortune and ill with an equal mind, full of resource in emergency, cheerfully undertaking whatever was within the powers of a man, he was ever considerate of the weaker and the less experienced; ready to add the burden 201 


\section{IN A FISHING COUNTRY}

of another who showed distress to his own huge load.

Broad-chested, lean in the flank, something over six feet in height and weighing but 190 pounds, his arm made no display of brawn; but the muscles were living steel, responding with swift precision to every call. The most touch-and-go situation, the uttermost demand, never seemed to exhaust the limit of his answering effort. Those who travelled in his company took their lesson in humility, for they encountered the pith of two men behind his paddle. The smaller and swifter Rice Lake canoe was proud to keep abreast of his heavily loaded bark,--he smoking the while, very easy and nonchalant, turning his eyes lazily to this side and that, like one out for an airing and bound nowhere in particular.

Your good ax-man is expected to fell, trim, chop to length and pile two cords of birch a day. $\mathrm{N}$ - did his three and a half cords, kept it up for a week, and had enough winter daylight left to aid an old man in completing his tale. What he accomplished by a neat half-arm stroke took another's full swing and the weight of his body. There was always the grace of exact proportion to the work in hand. 


\section{$\mathrm{N}$}

As a golfer might express it, his 'timing' was without fault.

A sight to marvel at was $\mathrm{N}$ - standing in the narrow stern of a cranky twelvefoot birch-bark, poised as easily and confidently as though upon a raft, while his pole drove it seething up a rapid. Those who have tried will remember - with not an inch to shift a foot, in heavy water, where all the power you have must go to propelling and guiding the kittle craft-the delicacies of inconstant balance to which the sub-conscious mind must every moment attend.

A two-and-a-half ton pilot boat was dragging anchor in a nor'-easterly gale, and in a few moments would be ashore. After a capsize in the surf, (vivid, yet, the recollection of ploughing a long furrow in the shingle with one's head!) a North Shore canoe managed to get out to her with $\mathrm{N}$ aboard. He seized one of the heavy ash sweeps, planted himself with broad stance in the leaping stern-sheets, and paddled the yawl against sea and wind out to a safe mooring.

He tells of a winter's night like to have been his last. Following swiftly and far upon the trail of a slightly wounded 203 


\section{IN A FISHING COUNTRY}

moose, darkness fell in a whirl of snow when he was deep in the woods, and his snow-shoe tracks were covered so rapidly that he could not return upon them. Without an ax, a fire of green branches would not serve to fight the cold. Lightly clad, fatigued and wet with the pursuit, he was in pretty desperate case. I do not remember whether he followed a traditional practice or merely copied the hare and the grouse, but this is how he managed to keep the life in his body. Taking of his coat and wrapping it tightly about head and shoulders he dived into a heavy drift, kicking and wriggling down and along till he was deeply buried. The hours till morning were miserable enough, and seemed endless, but the snow kept him from freezing to death and even from chilling beyond the danger-point.

A reillée in the woods; song and story had circled the fire. $\mathrm{N}$ - listened, smoked, applauded, but would not add his 'turn'. A round now began of the usual tricks and feats of strength. Though with perfect gond-humour, $\mathrm{N}$ - steadily refused to take part. Urging only brought the quiet remark:- Je porte mon canot. This indeed he did, and no one else could stand up 204 
under it for long. It lay just behind him - a bark that held five men with a mountain of baggage. To put it up by slow stages-aiding the arms with knee shoulder and back-required both knack and strength. Everyone of us welcomed a bit of friendly help when the great canoe fell to his lot. The men took to chaffing:- 'Ngrows old. Not what once he was. Il 'derient faible.' As the tormenting went on, $\mathrm{N}$-'s Je porte mon canot lost its jocularity, the smile left his face. At length the taunting was too much for him. Eyes snapping with anger, he loosed off a huge $\mathrm{O}$ Sapristi! sprang to his feet, caught the slender middle thwart of the great canoe with his left hand, and in one superb motion swung it above his head-the right hand never leaving his side. For ten seconds, man and canoe were a statue lit by the ruddy flame-before us, all amazed and silent. When he put it down with the same lightness and ease, cheers and bravos set the woods ringing. A hint of a smile told that the ruffled temper was smooth again. Quietly he said Essayer done ca, reached for his pipe, and became a spectator once more. Of course everyone had known from the beginning that $\mathrm{N}$ - could beat him at 


\section{IN A FISHING COUNTRY}

his own game, and no stricken fool in the party had the assurance to attempt $\mathrm{N}$-'s.

Sometimes it was hard for $\mathrm{N}$ - to understand that his matter-of-course performances were quite beyond the powers of another. A solitary instance where he seemed to lack confidence will appear the stranger when contrasted with this example of his perfect fearlessness.

A flotilla of canoes was about to descend the lower ten miles of the Murray, but the river was nearly ten feet up and mighty in its wrath, after three days of extraordinary rain. Thirty yards out from the launchingplace, and a little below it, a dangerous comber marked the beginning of a rapid so very wild that it could only be run in the easier water at the side. To engage upon the rapid at the right point it was quite clear that you must hold above the breaker, and some of us thought the current too swift for a canoe to make the course. The canoes were actually in hand, to be launched higher up, but $N$-'s opinion that the breaker could be weathered was allowed to prevail. With two passengers in the largest birch-bark, he crossed and gained the fairway without appearing to exert himself The second canoe had but one pas206 


\section{$\mathrm{N}$}

senger, and was trimmed by the stern, the better to meet the quick curling waves. This pilot was unable to keep $\mathrm{N} \longrightarrow$-'s line, and finding that he must be carried broadside against the breaker, ceased paddling and fell on his face to even the trim and lower the centre of gravity. The canoe smashed into the roaring white wall, climbed it by some miraculous luck, but was left approaching the centre of the rapid sternforemost. This, beyond peradventure, meant death in a few seconds to both concerned. There was nothing for it but a vault to the middle of the canoe, and this brought the steersman sitting in a lady's lap but facing the right way, with the craft on an even keel. It was then possible to haul water, slip by outside the swamping seas and sneak through scarcely wetted. Not so fortunate the third canoe. It filled in a moment and the bow-man was drowned...

For $\mathrm{N}-$, the peril had no existence, and he credited others with the strength and skill of that marvellous arm. Every problem of river-work was equally simple to him. Without a trace of boastfulness, he seemed to have no doubts that the waters would always provide a path which his canoe could find and follow. 


\section{IN A FISHING COUNTRY}

Once only was it otherwise. We hald done fifteen miles of river and portage in a downpour of rain. There was not a dry stitch in the party, nor a dry twig in the woods, and I remember it as a solitary occasion when there was real difficulty in making a fire. Wood from the heart of a dead tree was at length kindled with a match that had survived in a pack. (The evening looked and felt unpropitious for fishing: reason and the flesh both made their protest against paddling another couple of miles in the wet; reason was discomfited, the shivering flesh consoled by the killing of a brace of trout that weighed twelve pounds).

At five o'clock the next morning breakfast was under way, for we had before us two miles of dead water, a mile of rapid, another two miles of paddling and a drive of fifty-odd miles, - enough to exhaust the daylight. The rapid was a fairly stiff one for running without a pole; after the first steen pitch with an awkward crossing in heavy water, boulders set like the teeth of a harrow but not with so pleasing a recularity were the difficulty. You had to sidle back and forth, crossing and re-crossing with hard continuous labour, for un208 


\section{$\mathrm{N}$}

obstructed channel there was none; but it was an old story for everyone, and to $\mathrm{N}$ -

a trivial affair. Our custom was to despatch the living freight over the portage, divide the baggage and dispose it so as to put the canoes in the handiest trim. The idea of following any different plan had not entered my head, so I was utterly surprised to see $\mathrm{N}$-equipping a load with a tumpline.

'Why do that? There is no more carrying.'

'For the portage.'

'For the portage! But we run the baggage!'

'Le rapide est vilain;-mieux portager.'

'The rapid is safe enough - there will be more water than usual.'

'Yes, more water, too much and not enough. It will be ugly. We may smash a canoe.'

'No great danger of that, but what if we do? Our risk. The carry would take too much time.'

Grudgingly, almost sulkily, $\mathrm{N}$ yielded. The two French Canadians, finishing their breakfast beside us, followed the interchange with curious intentness; but the passing wonder at N-'s re209

14 


\section{IN A FISHING COUNTRY}

luctance, so unlike him, so stubbornly persistent, was forgotten in the bustle of departure.

The usual program went forward, the passengers were landed, the butin readjusted, and $\mathrm{N}$ - was off in the lead. Following on his heels, it was clear from the first moment that we were in for a bad passage. The extra six inches of water doubled the pace of the current, but left the boulders uncovered, or just awash. My canoe, a two-fathom bark, was the easiest to stop or to swing. Warned by a shout from behind that the steersman could not hold back his heavier Rice Lake, and must pass, I drew under the lee of a rock while he shot by; then my own affairs became entirely engrossing. Half-way down, a few yards of straight running gave three seconds to look ahead. A man was in the middle of the river, but no more than knee-deep, and one remembers that, beside a natural concern, there was a distinct sense of annoyance that he was blocking the only comfortable highway through the ugliest bit of the rapid. Passing, very inconveniently, some fifteen feet away, I saw that he was standing on the side of a submerged canoe which was receiving the whole weight of 210 
the stream (what we recovered afterwards would not have gone far toward the making of a ten-cent box of matches). Down in the pool below, $\mathrm{N} \longrightarrow$, his face sombre and fateful, held the big canoe in mid-current.

'Now you know why I was unwilling to run the rapid!'

'I do not. An accident! Who could have foreseen it?'

'I forsaw it; did I not try to warn you? I told $\mathrm{T}$ and $\mathrm{A}-$.

(He had: hence the strange interest they had shown in our conversation.) You, it would not have been wise to tell. All of this came to me last night in a dream. The face of the man in the canoe was turned from me-yours, I guessed. A mist fell, and the end was hidden. Trying to pierce it I awoke,thinking to myself it was death, no less, that had flung so black a shadow.' 

WAYS AND MEANS 



\section{WAYS AND MEANS.}

These pages are not for the man who has developed and matured a plan of life in the woods - testing, rejecting, adopting; till the sum of created things has been divided, for the purposes in hand, into indispensables and dispensables - the latter jettisoned, the former worked out in every detail to his perfect liking. I would be more comfortable sitting at the feet of such an one than proffering him instruction.

Nor am I competing with the shopman's encyclopaedic catalogue which reveals to us a host of unfelt wants he is not unwilling to supply.

Rather regard this, I pray you, as a gossip between learners, unhappily for both of us in monological form, where some random harvestings of experience are gathered into untidy sheaves.

Plunging then with the least delay into a large subject, there shall hardly be mistake in opening on foot-gear. A man is no better than his boots. Feet that are ill-shod and ill-cared for upset programs, and put distressful minus sign in front of all the items they comprise. When the boots you

\section{5}




\section{IN A FISHING COUNTRY}

stand up in must carry you through from day to day; where the going is hardrough and wet by turns-with slippery logs and stones, streams to wade, thick brush to be traversed, stretches of canoeing in between; there is a real difficulty in suiting every occasion. Heavy water-proofed leather to the knee is both hot and tiresome, though some manage with it. Rubber is unbearable. Lacrosse shoes are soaked at once, but dry quickly; they give no protection to the ankle, and little to the sole; yet these were long our favourite wear in a bad country, and they are merciful to canoes. For young light-weights, who can afford to be wet twenty times in the day, I doubt if anything beats them, but the life of a pair is barely a week. Middle-age asks to be better shielded at all points, and will not find comfort in what was designed for town. On the whole it seems a case for compromise:-a boot of horseor porpoise - hide to the middle of the calf, with a water-proof tongue, stout catches for strong leather laces, thick soles, a few tackets on the very low heels and just at the toe, otherwise soled with heavy rubber. Nails, where the weight falls, are brutal to a canoe. Equipped with Phillip's 'mil216 


\section{WAYS AND MEANS}

itary' soles and heels they are better still,probably combining all the virtues that a mortal bootmaker can assemble; but water will nevertheless find its way down, if not through, in the course of a long day in the rain.

Good boots deserve the best of dubbin; here is the recipe for one that is clean, without smell, and very resistent to water: Mutton-fat, six ounces; white-wax, six ounces; Canada balsam, four ounces; raw linseed-oil, three pounds. Boil slowly together for about an hour-until it cools to the consistency of vaseline. This has the further excellence of being an agreeable and very soothing emollient.

Some possess tender and enlightened consciences; others have the same discomfort with their feet. A light smooth pair of socks under heavy woollen stockings helps the second condition, for the first I have no remedy to propose. When a long tramp is in prospect, time can well be spared to soap the inside of the socks; a free lathering prevents blistering and soreness. On a walk that drew out to thirtyfive miles, over what bore the courtesy title of a road-the last two hours of it through wash-outs and boulders in the pitch-black- 


\section{IN A FISHING COUNTRY}

ness of an overcast night - a fine pair of boots yielded up their lives, but the feet animating them were fit to carry on next day; whereas a sturdy French Canadian who did not use this easy precaution was crippled, and had to lie up for repairs. It comes to mind that this very daunder gave a chance to test the advice of an old Irishman-a prodigious walker. In the days when dancers were less blasés, more than once had he stepped it thirty miles to a Toronto bail, stood up to the music all night, and turned his long strides homeward in the morning. This was the counsel: "When tired, and the road is long, do not bathe, as it weakens and relaxes; sit down in the first cool stream (breeches half-masted, shirt close-reefed) you will find yourself amazingly refreshed and braced.'

Oil-tanned slippers, or something else waterproof and light, will be needed for evening wear. One might add that canvas boots with thick rope soles, such as are made in Scotland, protect the feet in wading, and grip slimy boulders better than nails or rubber. Getting wet hurts no one who keeps going. Sooner or later you are bound to be over the tops of the highest 218 


\section{WAYS AND MEANS}

boots, and thereafter are worse off than if so lightly clad and shod that, when out of the water, you are in process of drying off. A composite picture comes out on the plate of not a few elderly gentlemen, reclining on the shingle with legs heaved uncomfortably heavenward, laboriously emptying their water-logged boots up their trousers!

A useful thing to have by one is a piece of thick adhesive felt, out of which a round can be cut with a hole in it of size and shape to cover bruise or blister. This quenches a pain that would grow to torture and gives the spot a chance to rest and heal. Whilst meditating human ills, an efficient substitute for a hot-water bag may be suggested. It has relieved internal miseries; perhaps saved life. Make a fire on the sand, and keep applying the heated sand in towels or handkerchiefs at the highest temperature bearable. I favour walking off a sprain, notwithstanding the horrid language it provokes from the patient; if too severe for the solvitur ambulando cure, nothing helps so much or so quickly as soaking in hot and cold water alternately, to the limit of endurance in each case. Capsicum vaseline, or another of the rubefacients, has most of the virtues of a mustard-plaster, and others 


\section{IN A FISHING COUNTRY}

of its own; you may rub it on indefinitely, and the agreeable warmth lingers. But probably everyone has a pretty clear idea of the half dozen simple remedies, not forgetting chlorodyne, boracic acid, bandages and pills, that should fill the cigarette-box in his pack.

Speaking of the pack, can a sailor's dunnage-bag be improved upon for general handiness? The dealers do not offer it, I think, but a sailmaker will turn them out of the size that may happen to suit your needs,-depending upon whether they are to hold everything required for two or three weeks, or only strictly personal traps, excluding blankets. A long opening in the side gives access, without that inconvenient groping to the bottom of a sack which generally ends in turning out all the contents. This opening laces up tightly, and in a moment, with loops of cotton cord served to one edge and passing through eyelets on the other. A carrying-strap made of the same eight- or ten-ounce duck is a fixture, but cords at either end regulate its length, these being attached to metal rings sewn about twenty inches apart, on reinforcing patches. Naturally you will not load it upon a wagon, mouth up, or in a 


\section{WAYS AND MEANS}

wet canoe, mouth down. The waterproofing you can best attend to yourself. Let the fabric have just so much boiled linseedoil as it will take up; after which it should be hung in the air and sun for some days to dry. This is important, because cotton cloth thus treated will heat and ignite if rolled up before the free oil has dried out. The same dose makes a flour-sack, or the lightest tent, quite impervious to water. Where a canoe was wrecked at an ugly corner, we picked up its load of bags in the pool some hundreds of yards below, not a penny the worse for running the last half of the rapid on their own.

Many years' traffic with that poetic craft, the birch-bark, does not hinder one from welcoming the modern canvascovered canoe. I recall a whole day lost in repairs; and again, a long run through bad water, where, under the most expert of handling, we had to land, unload, dry, and gum the barks five times; canvas would have come through unscathed. (A dab of boot-grease caulks a slight leak in it.) The canvas craft has the free-board, sheer and capacity of the birch, which are not found in wooden canoes of the same length; moreover the builders of the latter 


\section{IN A FISHING COUNTRY}

cannot be persuaded to place a thwart in the middle, and condemn you to carry with insufficient headroom, on paddles that spring and cut the shoulders. The greater speed of the wooden canoe is given up willingly for the many advantages of the other, although this has not yet been brought to perfection for rough travel and long carries. Better canvas and paint, with a lighter frame-work of cedar, would turn out a canoe for three men and baggage weighing less than fifty pounds, and fit, in good hands, to stand up to anything. One newfangled device deserves a word of praise. The pneumatic yoke gives ease in carrying a canoe; between whiles, as a cushion or seat, it falls into the class of things which are unnecessary but comforting. The Adirondack basket is not well enough known in our country as a safe and convenient means of transporting breakables and miscellanea.

For rapid unencumbered journeying the unit is inevitably three. One carries the canoe; another, tent, provisions, cooking nutfit; the third,--everything else. $\mathrm{He}$ is the human hat-rack. With this apportioning of the labour-cutting down all 
round to the barest indispensables - the ground is got over with no disheartening doubles at the portages. It is a true saying of a comrade in many a stiff voyage: plus de Messieurs plus de misère,-the word being commodious enough to cover all the discomforts, toils and misadventures that can befall on land or water. Aluminum utensils economize weight; small bags, for everything that can spill or take damage in the larger sack, will economize provisions.

I commend the woodsman's practice of halting for five minutes every half hour, or, at less intervals, if the difficulty of the way should call for it. Whether you carry on head or chest (the latter so constricts breathing and circulation that you are likely to prefer the former, when once the right adjustment of the burden to back and neck has been found) it is a great relief to drop the pack for a few minutes, letting pulse and respiration slow down. In what may seem but a small matter, the leader, choosing time and place for the rests, has room to exercise a useful tact. Stop after, and not before, a bit of difficult walking,steep pitch, windfall, stream crossing; there is spiritual refreshment in knowing that this trouble is behind, and not ahead. 


\section{IN A FISHING COUNTRY}

The principle applies in a larger degree to the day's work. Win to a spot where the mind can repose itself in contemplation of an easy and pleasant start on the morrow. Indians carry this to the point of running on in the dusk through dangerous rapids, so that they may not be haunted through the dark hours with the thought of attacking ugly water the next day in cold blood.

Sit so hard upon the man who announces he will 'go on ahead,' or will 'catch you up', that he shall be constrained to put away from him these individualistic yearnings. Accidents happen; plans have to be recast; people go astray, mistake directions, fall asleep. The speed of a party is the speed of its slowest member; keep together. What seemed, at the time, an innocent breach of the rule, cost us an irrecoverable half day, and a lot of needless worry.

The sudden flashing realization that you are lost is extremely discomposing; impulses to plunge at random are apt to sweep a man clean off his feet. Summon to your aid every inhibitive force. Throw off the pack, sit down, light your pipe, think. A moment gained at the crisis, and 


\section{WAYS AND MEANS}

you can sort yourself out; but unless the chance be snatched, the ability to frame an intelligent purpose may disappear for hours, or days.

One who suffered this misery told how it fared with him for a night and a day:- 'I tried to find the river-found it, and was almost swept away in a rapid-. took to the mountain-side and lost the river -sought to recover it-climbed and saw distant water - made for it - a lake and not the river-climbed again-another lakeanother mountain' ; and so on, till a searchparty made a lucky cast and chanced upon him, miles from river, camp, or any trail, striving through burnt windfall, famished, his clothes in shreds, quite distraught, but still clinging to rod, net, and the big trout which belated him at the fishing.

'The sun set and rose clear. You knew the river flowed due north and south,that you were west of it?'

'I knew all that once, and know it now, but the ideas never crossed my mind.'

Toward midnight, being very cold, he lit a fire which spread up the hill-sidetoo far away for our watch to see even its reflection-but never bethought him to 


\section{IN A FISHING COUNTRY}

cook the trout, or that food would be a help. Reason and judgment were in abeyance; impulses, scarcely more than primitive, were flinging him hither and thither without design. When the delicate balance of the mind is upset atavistic instincts thrust in, but they have ceased to guide trustworthily. One of our men, whom other experiences had instructed in the psychology of these cases, told us that, with exhaustion, the faculties resume control, it becomes possible to think lucidly, and then the wanderer may extricate himself should strength remain. But the return of mental power is at the expense of such physical collapse that the issue is doubtful. Wherefore, dam the emotional outrush by every mechanical means, - throw off the pack, sit down, light your pipe, think.

Not the tenderfoot alone is exposed to these disabling panics. Clovis, Indian of the pure blood, accomplished in every line of sport (and poaching), old hand on the grand's royages, was hardly able to tell for laughing, how that once he was utterly lost in his own wood-lot. According to the tale-needing woefully an accompaniment of moving pictures - the earth made a half turn with abrupt malevolence, set- 


\section{WAYS AND MEANS}

ting itself down where north was south and east was west. Accepting these new compass points, as his mind insisted should be done, he presently came out on a clearing his ax had made, but failed to recognize it from a disoriented point of view. A fresh departure carried him to something else which should have given him a line for home, but only served further to confuse a twisted mentality; and, shortening unduly the diverting narrative, he, a practised woodsman, floundered helplessly around his own back-yard (as it were) for a couple of hours. He had no explanation, nor have I; but if that stable universe of his could behave so disconcertingly, you or I may sometime find ours in the same frivolous mood.

Keeping together is good sense and good manners: there are further heads of etiquette governing the march. Hold your place in the line, never pressing ahead if the leader stops or misses the road; should you be leading, have those behind in the tail of your eye, so as not to outrun the slowest or push the heavy laden; strive for an even pace,--setting it with relation to distance and difficulty; halt and start together, for catching up over a doubtful 


\section{IN A FISHING COUNTRY}

trail takes it out of a man; let the other fellow's pack alone, sit on your private effects if you want to, but not on his; disembarrass the ends of the portages of yourself and burden to allow free passage for what deserves first consideration, the arriving and departing canoes. The prudent traveller's first maxim has less application in the woods than elsewhere, but even there it may be said that a fool and his baggage are soon parted.

As the day wears on, chances may come to those less encumbered of lending a hand in the adjustment of canoe or pack. What is tossed on the head so lightly in the early hours, goes up later with strain and clenched teeth. You will recall the stone by his door at Abbotsford which Sir Walter Scott lifted in the morning with ease, but could not stir in the afternoon. One thinks, too, of the pathetic entry in Hubbard's diary of the Labrador trip, where he puts himself down as good for a load of one hundred and fifty pounds-after a few paces on the level strand! How the pack dwindled on that long last trail! The French Canadian, who stands up to his work and carries with any man, knows this waning of the strength; and whilst, making 
little of your burden, he will add it cheerfully to his own, he appreciates the thoughtful courtesies of the portage,himself practising them continually, unobtrusively, instinctively. There is an order of precedence on both land and water, determined by seniority or skill, but every man leads as of right in his own country. Where you are invited to go first, it is a compliment paid, and to be acknowledged. One who, crowding to the front, hears no comment, must not infer that his manners pass unnoticed.

The good Père Le Jeune once proffered some odds and ends of advice to young missionaries joining the devoted land across the ocean-advice designed to save them from 'getting in wrong' with the heathen. 'The heathen' are yet with us, and these hints as to conduct and demeanour have lost no whit of their shrewdness and wisdom in 300 years:-

'You should be prompt in embarking and disembarking.... and not carry either water or sand into the canoe... It is not wise to ask many questions... nor should you yield to the itch for making remarks about the journey-a habit which may be cultivated to an excess. Silence is a safe 


\section{IN A FISHING COUNTRY}

and a discreet plenishing... Should there be need of criticism let it be conducted modestly... In a nutshell, it is well to be cheerful, or at any rate to appear so... Everyone at the portages should try to carry some little thing according to his strength... be it only a kettle... undertake nothing unless you have a mind to carry on: for an example, do not begin paddling if you are not prepared to continue paddling... stick to your place in the canoe... Be assured that if once you are set down as a troublesome and difficult person you will not easily get rid of such a reputation.'

The man used to rough walking steps over everything, and never upon it; saving, in the day, a pretty enough total of footpounds to justify the habit. Follow him there, but perhaps not in his readiness to allumer at every chance-with strong tobacco at that. Better turn off a few miles first, to get heart and lungs in running order; otherwise the pipe may be little of a solace.

It is a commendable dodge to put a bit of hard-tack or chocolate in the pocket at breakfast-time; what feels like crippling fatigue is often what an Irishman calls 'the hunger-weakness'-the furnace pray- 


\section{WAYS AND MEANS}

ing to be stoked with a few mouthfuls, of biscuit. There is no harm in drinking on the march, as much and often as one pleases, and a rubber cup is highly convenient; but it is dangerous for man or horse to touch cold water after long exertion, before cooling off. A good horsemaster allows the animal to drink freely, a mile or so before the end of his journey.

However chilly the water is, a plunge is safe to one overheated; unsafe when the body dreads it. Hurry up and get in, but do not swim far if tired, for cramp then lies awaiting. It may now be in the nature of an empty counsel to declare that the most insignificant amount of alcohol is a definite hindrance, and no help, in any kind of work; - vainly and sadly reminiscent, too, the praises of that unstinted noggin at the long day's end-reward of labour-healer of fatigues-grave-digger to sorrow-begetter of rosy dreams!

Pork and beans I know, catalogne I know, but what timber else is stout enough to prop the ribs from sunrise to sunset? Other foods evanesce; by early afternoon they are but a haunting memory. Herein is a mystery: give to the Scot his oatmeal, the Irishman his potatoes, the Arab a handful 


\section{IN A FISHING COUNTRY}

of parched corn, and each is fit for the longest toils; - not so with us. I suppose our stomachs are not attuned, or perhaps it is sheer capacity they lack. When the larder was low, we often strove to engulf a sufficiency of porridge for the day;--a plateful, a slow concentrative dance, another plateful, another dance, and so till we could no more; but the treacherous oats never stood by us; hunger and weakness always impelled to the biscuit-sack before supper-time.

Perchance you have met catalogne under another name, and will recognize it, in free translation, as 'door-mat'. If not, let me tell that this plat de résistance is artlessly confected of flour, water and pork,-the last cut in dice and fried till there is plenty of grease, when the commingled water and flour, beaten till unlumpy if your skill should go that far, is poured into the pan. One inch is a good working thickness for the pancake, which you may toss again and again without peril to its integrity. An average rather than a uniform cooking is your inevitable aim; black on the outside, it will be virgin dough at the heart. This is in no sense a pre-digested food, but gives honourable employment to 


\section{WAYS AND MEANS}

the pancreas. Shaved maple-sugar is the natural garnishing, and furnishes additional calories.

Arrived at the camping-ground, a party of motley composition will sort itself into those who know what to do and do it forthwith, those who are willing but don't know how, and those neither able nor willing. (The fourth possible class has no existence in fact.) The first need no word; there is nothing but admiration for the way in which they size up the needs of the case, find an answer to questions with their own eyes, turn their hands to the most helpful job. With a little instruction, the second class can be used in this way or that; they have promise of rising in the scale, as intelligence shall digest experience. Of the third, least said soonest mended. Let them go and swim or play quietly somewhere out of the way, - not forgetting however that they too possess human attributes and are capable of purposive action if a dullish spark could but be blown into flame. Quench not the flax by any unkind word, should it smoke ever so meagrely.

The moment that tents are pitched, the fire going, wood provided, beds made of balsam or spruce, supper on the way, is the 


\section{IN A FISHING COUNTRY}

time for getting into your dry change-before the blood runs chilly. Make a new commandment of it; nature will provide the sanctions. But having attacked a broad theme in topsyturvy fashion, I must now strive for some kind of order in disorder by suggesting the outfit you are about to discard. Advices so far have only extended to boots. Important as these are, it is to be hoped that you have not been exposed to discomfort through my delays in providing a completer wardrobe. Accept this late amends.

Working clothes, either in summer or winter, must be light; contrary to catholic and apostolic doctrine I have no use for woollen undergarments at any place or season-even when sustaining the indoor rigours of an Englisil winter. Warmth resides alone in the non-conducting air, which is imprisoned as effectively by linen-mesh as wool. The former receives perspiration more readily, and disperses it more promptly. Parenthetically, you will suffer less, thus garbed, in our over-heated buildings, and colds will diminish or cease. Linen, or a mixture of linen and cotton, meets every requirement of night and daywear in the woods; - two suits of it when 


\section{WAYS AND MEANS}

the thermometer is far below zero. But in the present state of the craft a good thick flannel shirt is inevitable--two of them rather: the one in your pack, with spare trousers, socks, underclothes, moccasins, sweater or cardigan; to be kept most sacredly dry, never worn in the daytime, always donned at the first possible instant after the day's work is done. The alternative of shorts or longs may be disposed of according to individual conformation and liking, but there are reasons for preferring knee-breeches by day, trousers by night. Having shifted into this gear, nothing remains but to slack away everything when the hour comes for turning in. I happen to be a pre-pyjamic survival, but have seen these epicene garments used in the woods without apparent ill results:another undressing, of course, and so much the more to carry. Sleeping in a coat interferes with the flow of blood and chills rather than warms. Thow it over shoulders or feet. A second coat in the woods is as useless and cumbersome as the ' $\mathrm{e}$ ' in 'axe'.

As one cannot work in a mackintosh or oilskin, these sink into the list of comfortable things that are not strictly necessary,235 


\section{IN A FISHING COUNTRY}

barred therefore from a light pack; yet it is of great advantage to have a coat that will turn a shower and still is pervious to moisture from within. So high an authority as Stewart Edward White is for rejecting a coat altogether. Might his opinion not be revised in favour of a garment that was light, of a texture that would not tear or lay hold of twigs, fairly rain-proof, drying quickly, keeping out the wind, abounding in pockets? Burberrys first supplied such - casting back to an old spelling and misapplying an old word for their 'gabardine'. When it loses the duck's-back quality, (as arrives in the course of time) a dash of boiled linseed-oil on the shoulders gives protection where most needed, and camouflages the wearer by making his aspect less monotonous. This fabric has the merit that snow does not stick to it,- -with yet another to be spoken of later.

It probably wastes two lines of print to observe that an overcoat, at all times, is sheer lumber. In heavy winter tramping you can wear little more than in summer: as to the feet, oil-tanned moccasins with three pairs of socks; a sweater beneath the coat that changes not with the changing seasons; a woollen cap drawing over the 236 


\section{WAYS AND MEANS}

ears; on the hands, old loose dog-skin gloves, under warm mitts that hang about the neck by a string when pulled off. The bare hand cannot endure a rifle-barrel in severe cold. A summer hat ought to shed the rain and be accommodating to the packstrap.

The pack's contents are now fairly well disclosed:- the jealously-guarded dry change, perhaps an extra pair of socks, washing and shaving-tackle. At the risk of being classed with sybarites, I plead for a small rubber sponge to aid precarious toilets by the edge of stream or lake. Handkerchiefs are another blameless luxury; illusions of dressiness and refinement are cheaply induced by breaking out a clean one every now and again. A large bandanna will not be amiss,- - shielding the neck from flies by day, and one's ears from the rugosities of boots by night.

But here acknowledgement must be made that age and the growing love of ease have sapped a disposition long content with impromptus: I carry a pillow,-only a little one of a few ounces. More deplorable still, a down-quilt has to be confessed; but reason and sense excuse what gives you three times the warmth of the 


\section{IN A FISHING COUNTRY}

same weight in blankets. Adding a light blanket you are still not overburdened, and may have your rest at night without arising to mend the fire at twelve, and two, and four. In substitution for these coverings, a down sleeping-bag is a marvellously comfortable thing out of which to blink at the chilly twinkling stars. Keep it dry, for drying is a slow and troublesome job. The other shop-made sleeping devices are heavy to transport, with further disadvantages; a simple bag of water-proof duck, holding the bed-clothes about you, and fending off wind and wet, is both handier and better. Make it with a smaller bag at the head, for your traps and to serve as pillow. But even this may outrun what is permissible when travelling light. The greatest possible warmth for weight is found in a rabbit-skin robe; - hard to come at now, since our squaws have turned against chewing and weaving the strips of fur.

There is always room for a book or two. Some authors might be flattered at knowing the trails they havestaggered over. This suggests a new literary touch-stone: books worth carrying fifty miles on your back! Some day I should like to apply it. There 238 


\section{WAYS AND MEANS}

is only room here to express a doubt that the result would accord very well with certain classic lists.

A pocket aneroid, and a smattering of meteorology, give to life a new interest that blossoms into a cherished hobby. Every hour something falls to be observed that will start a deductive or inductive train. The field of atmospheric reaction upon men, animals, birds, fishes, insects, lies broad before one. Numberless saws and sayings may be assigned their place in ordered scheme, or traced into the twilight of sacred myth or secular fable. Weather signs, both local and universal, ask to be fitted in with laws, or with those habits of the air to which our ignorance is unable to award the dignity of law. The whole meteoric array takes on new meanings,suggests problems the more intriguing because the answers affect our movements and concern our welfare. Glancing at this pursuit,-all that is permitted to one who is upon an enquiry as to what a man shall eat and wherewithal he shall be clothed-I leave it with a query rather than an affirmation: are not the critical hours of the twenty-four in summer-timewhen change or intensification of weather 


\section{IN A FISHING COUNTRY}

may be expected, and the best indications as to the future are discoverable-about 4 a.m., 11 a.m., and 7 p.m.?

In the matter of tents, some radical views are exposed for those willing to prove all things, and hold fast that which is good. The common designs partake in the same defects. They are heavy for their sheltering capacity, awkward to move about in, slow in drying, smotheringly hot when the sun is upon them, incapable of being warmed except by a stove, stuffy to suffocation when closed, a trap for fliesyou being the bait-which repose themselves aloft and await their hour. A tent modelled on the woodland lean-to is without these failings, and has further points to its credit. Let me give the specifications of one put together out of light duck by a village cobbler. Designed, and comfortable, for six men, eleven have slept there dry on a rainy night. Six thirteenfoot lengths of the cloth sewed side by side form the body. At one end of this rectangle are eyelets with loops of cotton cord for pegging, edge to ground. Ten feet away a transverse sleeve of duck is sewed to the inside for the ridge-pole to pass through-this preventing any shift in the 


\section{WAYS AND MEANS}

three-foot overhang. The projecting ends of the ridge-pole, at a height of six foot six, rest on crutches, or, better, on crossed poles tied loosely together, which slacken or tighten the tent at need when they are opened or closed scissors-wise. From the reinforced corners of the overhang long stays of cotton cord run out to tree, stump, or peg, and form convenient drying-lines. To assist eye and mind in framing a picture, line by line, nothing has yet been said of the wings-integral parts of the construction, adding much to its usefulness and comfort. These are triangular, built up in the same fashion and sewed to the body from ridge-pole to ground, with loops to peg down the lower edge at an angle a trifle broader than a right angle-so that they will stand out a couple of feet. Beneath them, and at the head of the tent, is ample storage-room for provisions. Every man will have his two foot six by ten, with six foot six of head-room, which he may keep ship-shape and tidy, or like a hurrah's nest, according to his habit; but swift discouragement is to be expected should he encroach with his person or possessions on other allotments. The whole tent's company can arise, retire, dress,

\section{1}




\section{IN A FISHING COUNTRY}

undress, at one and the same time-in wet weather without touching the canvas and starting a drip. Given a choice, you will pitch such a tent back to wind; it is no great matter however, for the overhang, and the dead air inside, hinder even a driving frontal rain from falling on the sleeping-place. In ten days of wind and wet from every quarter, we never found it worth while to shift. The fire can be lit almost beneath the overhang. A current of warm and smoky air, passing continually along the ridge-pole, drives the flies from their favourite lodgment; indeed they seldom enter. In the wettest night, clothes, and even boots, will dry up aloft, with no risk of being scorched (hung conveniently on the ridge-pole sleeve by safety-pins). The heat is reverberated from the sloping roof; coatless, you sit at comfort after supper, in that shivery hour when the blood is drawn to digestive tasks, and the evening chill steals down from the hills. There is ventilation at all times, with coolness by day and warmth at night. A fire quickly dries the canvas, lessening its weight by many a welcome pound. The tent described is half a man's load, but pocket and purpose will govern size and material. Needless 242 


\section{WAYS AND MEANS}

to say, it is much cheaper to build such a tent than to buy an ordinary one of the same capacity.

It is worth the noting, that a miner's (or better, a foreman's) acetylene lamp, with carbide, weighs less than the equivalent in candles, gives abundant light for reading or cards, and does not blow out. Should it be necessary to cover a rough trail in the dark, this makes quite simple what is not easy of accomplishment, even with birchbark torches.

There was a promise to disclose another virtue for 'gabardine', and this turns upon the colour. The fact slowly forced its way home that flies prefer dark things and dark people. Perhaps this has to do with the absorption of heat rays, or the choice of a protective background, or both. Brunettes suffer more than blondes; Indians are badly bitten; black horses and cows fairly run blood in fly-time. It was the canoeman's dark hat, with black-flies crawling over it by the score and circling round it like a saint's halo, which gave the final proof. At the same moment my own gray felt would be almost deserted. This settled the practice of wearing lightcoloured clothes in the woods; I commend 


\section{IN A FISHING COUNTRY}

it heartily, if the empiricism be not already a part of your own stock-in-trade. Years afterwards, confirmation came across the ocean-from experiments with the mosquitos of the Campagna. At some spot where the game was plentiful, square metres of the same fabric in a wide range of colours, were exposed. Speaking broadly, black, and the dark browns blues and reds were found to be popular, the lighter shades unpopular. Dried mud, khaki, ('gabardine's' usual shade) was the last colour of all which the mosquito chose; between this and purple the difference was, as I remember, one to a hundred. (A Gallipoli campaigner told me that he had reached the same conclusion as to lice and blankets.) Wherefore the man who wears a blue flannel shirt in the woods offers a standing invitation to the enemyasks for all he gets.

The only real objects of pity are those who swell when they are stung; for them there is hardly another counsel than to keep beyond reach of flies. One such unfortunate developed ears that flapped like an elephant's; his mother, at their meeting, claimed a voice as the voice of her son, for his face was not the face of Jacob. An244 


\section{WAYS AND MEANS}

other had to be led, morning by morning, blind as a puppy, to the cold stream, where patient soaking reduced his swollen eyelids till he attained a glimmer of vision. A third fought the flies like a demented alcoholic, with ravings and fury incredible in a man of natural meekness, and withal of strong religious conviction. Time is so kindly a deceiver that perhaps all three cherish a happy memory of those far-away days,-might be willing to recover them, if ever the film could be reversed upon the screen; but as it then was turning they heartily wished themselves away from Beelzebub's host. Yet it may be that their torments worked the heroic cure, by inoculation.

One moist still afternoon, when falling line and breaking fish were obscured by the hovering swaying cloud, I stuck to it with the help neither of oil nor tobacco, for no better than a boy's foolish reason that the trout were rising well. A curious friend made a count of bites at the rate of fifty to the exposed square inch (this by no means exhausted the total), and performed some prodigy of figures in arriving at the sum of them. (A dollar a bite would have assured me forever against 245 


\section{IN A FISHING COUNTRY}

want.) There was malaise and fever for three days, but the dose of poison brought future immunity from swelling,- - not, of course, from being bitten. This is endurable, though unpleasant; no one enjoys being crawled over and explored by flies or swallowing them. But a good oil, often and freely applied, together with a resolute abstention from soap and water, will soon make one proof against any but the most determined attacks. In the face of a really serious offensive there is nothing for it but to cut and run.

An evening on the stream ominously named the Rivière des Mouches comes to mind,--warm, damp, windless, at the very peak of the gros coup de mouches. Oil made no particle of difference. The flies invaded eyes, ears, nose; but, straddling a smudge, gulping an occasional breath, one could step forward a pace from time to time, and make a few hurried casts. The doleful and gory countenance of the boy huddled over the fire suddenly fetched up such a picture of my own wretched case that we went leaping homeward like the devil through Athlone,- - before the rise was over. It simply wasn't good enough. Standards of comparison should be used 


\section{WAYS AND MEANS}

charily: when the sweat is coursing down your nose, it is time to talk of being hot; when one has to oil up on a rapid walk, then the flies are truly bad. A few adjectives ought to be laid by against need, or the fitting word may have lost all its freshness and bloom when the time comes to speak of that lower deep beneath the lowest deep.

Flies hunt by scent. Their noses must indeed be keen, and the human smell vastly subtle to the creatures it attracts or repels. The momentary slant of a winter gale will turn a caribou at half a mile; flies follow up their prey from afar. When out on the water and free of them, beware an approach to the lee side of lake or river; on the other hand, you may work close to the windward shore without risk of taking on an unwelcome crew. A gentleman who makes a living out of such queer knowledge, informs me that the lady mosquito cannot lay her eggs 'till she has a full meal of blood'. How the poor dear must hate anyone who interposes a film of oil betwixt her and her repast! For the clogging of her delicate proboscis is inconvenient or fatal. The conjecture is permissible that blackflies and sand-flies have an equally good 247 


\section{IN A FISHING COUNTRY}

excuse for their small borrowings, and they too are more or less balked and disconcerted by an oily medium. This necessary ingredient of a repellent should have body enough not to dry off quickly. The other essential must be pungent-to override or mitigate that which allures the horde; our fashionable perfumes would probably serve, though there is no occasion for using anything so disagreeable. Crude petroleum and oil of citronella in the proportions of twenty to one, will answer well, but is not very lasting and tends to burn a delicate skin. An excellent mixture, for one who is not pernickety about his complexion, is pine-tar, three ounces; castor oil, two ounces; pennyroyal, one ounce; simmered over a slow fire; but there is choice for all tastes within the general formula. A remedy handed down by generations of fishermen-sovereign against the pain, itching and swelling of all poisoned stings-is acetate of lead, three drachms; carbolic acid, four drachms; tincture of opium, four drachms; rosewater, four ounces.

The mosquito breeds in still, the blackfly in running, water. Why is it that the latter are never more plentiful or annoying 248 


\section{WAYS AND MEANS}

than upon a hill-top, or a dry plateau, remote from any stream? How do they come there, and what do they seek? These are among the many questions which average ignorance cannot answer. An incredibly small number of these creatures must find conditions allowing reproduction; otherwise man would be driven from the woods. The Anticosti flies used to harry Mr. Menier's cows into early graves. These unhappy ones were the only fourfooted mammals on the island, except bears-whose ancestors probably arrived on ice-floes or drift,-foxes, otters, martens and mice. The owner disturbed the balance of nature, not with any kindly thought of the flies but for his own purposes, by introducing caribou and hares; an unexpected by-effect has been the shifting of the flies' attentions to the hares, and the consequent survival of the cows! There is a marked variation from season to season in the size and ( $I$ think) the disposition of the swarm: may it not be that in a good year for hares we are less troubled by the common enemy? Conversely, is there not a relation between the falling off among the hares every seventh year and the flies' activity? 
Black-flies choose low cover, and worship the sun; a warm hour in October brings them out after nights of keen frost. Exposed camping-grounds, with moss, shrubs, bushes and tall grass, are to be avoided. Quite bare spots are freer of them, and they do not harbour in the close shelter of trees. For mosquitos a smoke, for black-flies a flame,-if you would consult their dislikings. A dragon-fly or two, imprisoned in a house, will keep it clear of mosquitos. Other things being equal, make choice of a companion who does not use tobacco; you can deflect most of the flies to him with your pipe.

The air of the city knows no peace. Were it made visible, how would the confused sea of brutal noise that beats about us confound the eye! Our voices, striving to assert themselves above the din, take on a loud and strenuous tone; nor is it easy to attenuate the volume and the stress. Yet this the price for much that is to see and hear in the quiet woods:- -seen and heard, that yields so great delight. The pitch and quality that barcly prevail in street or car thrust out obtrusively from the subdued background of whisperings and murmuringsin as gracious keeping with the tranquillity 250 


\section{WAYS AND MEANS}

as is a bill-board with the field of rippling grain whence is proclaimed its blithe cathartic message!

The stillness of evening fetches the slender pipe of a bird from half a mile away; from two miles, the words and music of a song,-measuring the transmissive faculty of untroubled air. It were as well to travel in the company of a brass band as with habitual voices and ways. The tap of a pipe on the gunwale is sure advertisement to all the acute ears that something alien is abroad. The caribou in the water round the bend, the fox at his morning toilet on the bank, mink or otter fishing from the stones, take the hint and depart. Even the tiny click of a camera-shutter is heard by an unsuspicious feeding moose at eighty yards, and brings him instantly to the alert. Carrying power depends upon purity of tone - common knowledge of course, though perhaps little used.

Among a score of famous singers at the Albert Hall forty years ago there were but two whose lightest note filled the huge building-floated through it like a silver chime. The stressful effort of others could hardly avail, but Patti and Sims Reeves (in their great days) sang with drawing- 


\section{IN A FISHING COUNTRY}

room ease; for theirs was the gift of inducing a perfect. vibration, devoid of warring overtones, hampered by no defect of articulation. Everywhere, the far calls of the woods are musical, never are they shouts or screams. Nature's deepest note, of unsurpassed musical quality, is the low of a cow; thunder the loudest. It is said the cow's soft moo carries further than the earsplitting crash-a confusion of noises that tumble over and defeat one another. The statement, if open to question, is not absurd; timbre is more important than volume and must be controlled.

One who was in a deer country with Selous, told that as they neared the ground where the animals were supposed to be, the famous shot said to him:-

'I am afraid you will have to stop talking.'

'But, you!-you are speaking as loudly as I!'

'Yes, so you might think, but you would be heard at two hundred yards, I, not at ten.'

As the woodsman ever does, he had taken the edge (upper or lower edge it may be -what gives the resonance) from his voice, though still he talked, and did not whisper. The dulled words lost the power of travel- 


\section{WAYS AND MEANS}

ling; fell from lips to ground, though clearly audible to him for whom they were intended. Selous' acomplishment is worth the learning, and the practising. Put on the mute as soon as the foot falls upon the trail, sinking and modulating into close accord with the woodland orchestra, or the accompaniment will be drowned.

All this: and as yet nothing, beyond a hint from a Jesuit Father, of the two utterly important equipments for the nomadic (or any other) life-vision; an even mind. Unless we project ourselves into the future, and conjure up in due succession the situations to arise, there comes, to our confounding, a time and a place where some flaw reveals itself, some indispensable thing is found lacking. But by no means will it answer to give a carte blanche to fancy, and indent accordingly. The extra canoe calls for another man to carry it. He must be fed and sheltered at the expense of yet another back and legs which ask, in their turn, further canoe capacity, more pounds of flour and pork, -an endless progression. Prevision discovers what will be needed, and when, and where, for the unfolding of a plan comfortably, without hitch; thereafter the problem is akin to the mathe253 


\section{IN A FISHING COUNTRY}

matical one of finding the least commor multiple.

If character be immutable, the manifestations of it are within control; else were it a mere aggravation to say that petty misfortunes, ill borne, make a fool (and a bore) of the grumbler, whereas he who bears them handsomely makes a fool of his misfortunes. How profound the wisdom of the old man of Cadiz, -

It wouldn't be that which it is.

If it were what it weren't,

For he early had learnt

Who said that life is what it is,

The practical application of his philosophy is to take things as they come. Not as the uncomplaining ass meets his fate, for a disposition that permits itself neither enthusiasms nor revilings is dull to live with, in the woods or out of them. The man able to depersonalize affliction, can entertain you very well indeed with an account of his sore toe. Because he rises to a view of himself as merely that member of the human race he happens to know the best, can best talk about-contemplates the ever-interesting species through the individual. Even am I willing to listen to a man telling about his unhappy round of 


\section{WAYS AND MEANS}

golf, if the talk be conceived in that spiritbut I drift.

A parson, full of years and dignities, made little of fatigue and flies,---of all the unaccustomed things which must have been several torments to one whose ways had long been ways of pleasantness. His sufferings were only measured for us by a violently red undershirt and a word spoken to his own soul. The colour of the garment was not fast. It ran, and working outward, imparted with successive labours a deeper tinge to all he wore; yet his spirit was unconquered. A day came when, ruddy with the transuded dye, he stood beside the best and the remotest pool, giving butt to a huge trout that was tearing down the current. Above the scream of his reel and the roar of the fall I caught mutterings not intended for any ear:-

'It's worth it all! It's worth it all!'

Gallant old boy!- fishing now, I'll warrant you, some Elysian stream, if the Management does not deny the glorified what things they loved best upon the earth.

At four in the morning, cold rain drumming on the tent, I heard one struggle with wet clothes and boots. Twelve hours later he returned-twelve hours of scrambling 


\section{IN A FISHING COUNTRY}

through the wildest mountains in unceasing rain, never a dry stitch upon him, thermometer just above freezing, not a glimpse of caribou or moose. There could be no wetter, colder, more dog-tired man; but the smile carried away in the bleak dawn was still upon his face, when, from the comfort of my blankets, I threw out a greeting,'coarse weather, Mac.!' 'Yes', he cheerily replied, (and the hyperbolism, racy of the West, showed that one to the English manner and manor born had been rather successfully acclimated) 'a thirty-third degree _- _ net'. Apart from the smile, any well-grounded student of the laws could reassure Mr. Owen Wister upon the point that the words were used as words of purchase and not of inheritance. 
THE BROOK TROUT 



\section{THE BROOK TROUT}

A fisherman who dissipates much of his life in the practice of the law deplores his inability to sort out the Malacopterygian Teleosteans and to keep them tidily under his hand. He suggests that trivial preoccupations may have a like effect in other quarters as to this so important head of knowledge: wherefore, and to counter an ignorance thus perilous, he invites a brief addendum about the brook trout and his kin.

One really knowing anything of the subject would approach it with hesitation and distrust: this writer is unembarrassed. Reporting only the views of others, he barely takes the liberty of throwing in some observations to arouse a wholesome spirit of controversy.

The first of these may well be that no two classifications are quite in accord. He has but accepted a recent one. The best informed seem the least confident and the readiest to admit that the last word has yet to be said. Once the tendency was towards the multiplication of species and sub-species; at present it is in the opposite direction. 


\section{IN A FISHING COUNTRY}

As to some of the charrs there has not yet been opportunity for decisive examination and final opinion. Probably environment has received insufficient credit for bringing about differences that seem, at the first blush, striking enough to warrant discrimination. The terminology shows excesses, and perhaps defects. The North American charrs are said to be under competent study at the present time, and it may be that this will lead to revolutionary conclusions Much uncertainty arises from the multiplication of names, many of them misleading; sportsmen have it in their hands to cure the evil by rejecting all but those which have the best title to live.

My brief says that the family of the Salmonidae belongs to the sub-order of the Malacopterygian fishes, and embraces the sub-families of the Coregoninae (whitefish, lake herring) and the Salmoninae. Of Salmoninae, the genera are: Salmo (1), Oncorhynchus (2), Cristivomer (3), Thymallus (4), Salvelinus (5). It is with the species and sub-species of Salvelinus that we are concerned.

These are given as fontinalis (6), fontinalis agassizii (Dublin Pond), parkei (Dolly Varden), alpinus (saibling), alpi260 


\section{THE BROOK TROUT}

nus alipes (7), alpinus nitidus (7), alpinus stagnalis, alpinus arcturus, alpinus aureolus (Sunapee trout), oquassa, oquassa naresi, oquassa marstoni (7), lemanus (Lake of Geneva).

(1) The genus Salmo covers the true salmon and the true trouts, of which our rainbow, irideus, is the only one indigenous to the continent on this side of the Rocky Mountains, unless the truite saumonée of the Trinity and a few other rivers be the true sea trout (Salmo trutta), as seems likely.

(2) Oncorhynchus is the generic name of the so-called 'salmons' of the Pacific coast.

(3) Of Cristivomer there are but two species, namaycush and siscowet, but a bewildering number of local names are in use:lake trout (the one to be favoured), salmon trout, salmon, trout, gray trout, lunge (not maskinonge,) forked tail, tourilli, touladi, etc., etc. The fish is infallibly distinguishable by a group of teeth on the crest behind the vomer, absent in Salvelinus.

(4) As to this classification of Thymallus (grayling) authorities differ.

(5) The charrs (genus Salvelinus) are not 'trout' from the stand-point of the ichthyologist; they are withuut vomerine teeth. 


\section{IN A FISHING COUNTRY}

(6) Fontinalis, our brook trout, is best thus identified whether in brook, river or lake, long as the finger or the arm, black as an eel or radiant of colour. Perhaps no fish varies so much in every trait, with environment. There is just room for a doubt as to whether the species is divisible, but the question turns almost wholly upon size, not a satisfactory ground on which to base a distinction. Here too are there many names:- speckled trout, mountain trout, red trout, bec croche, etc., and confusion is born of this superfluity. Our so-called 'sea trout' are, almost certainly, brook trout which have learned to spend much of their time in salt water, thus acquiring new characteristics that possibly entitle them to subspecific classification. The North American brook trout is the most distinguished among the charrs, but, unlike the brown trout, (Salmo fario) he has not profited away from home.

(7) Nitidus and alipes were discovered named and pictured by Richardson in the far north, more than eighty years ago. The differences between them are trifling-so trifling that they may ultimately be classed together. Lac de Marbre trout, Malbaie trout, oquassa marstoni, are only slightly 


\section{THE BROOK TROUT}

distinguishable from nitidus, and the earlier name of this rare fish is entitled to prevail if they are identical. Note, however, that the marstoni of the Cassette lakes show, in photograph, very distinct spots, of which the Malbaie trout have no trace. The Malbaie trout is purely lacustrine, quite without the anadromous instinct which fontinalis, using the word anadromous in the broadest sense, never wholly loses. That there is something of an open question with regard to the Malbaic trout appears sufficiently from the fact that three sets of authorities-each a shade more authoritative than the last-have all placed it differently.

These provisional statements should be safe-guarded by the remarks that there are fish now known, on behalf of which unadjudicated claims are outstanding, and that our innumerable unfished waters are almost certain to yield new species and variants.

\section{Warwick Bros. \& Rutter, Limited}

Printers and Bookbinders

Toronto 




\section{PLEASE DO NOT REMOVE CARDS OR SLIPS FROM THIS POCKET}

UNIVERSITY OF TORONTO LIBRARY 
